\title{
ONE-TO-ONE COMPUTING AND STUDENT ACHIEVEMENT IN OHIO HIGH SCHOOLS
}

\author{
by \\ Nancy L. Williams \\ Submitted in Partial Fulfillment of the Requirements \\ For the Degree of \\ Doctor of Education \\ In the \\ Educational Leadership \\ Program
}

YOUNGSTOWN STATE UNIVERSITY

August, 2014

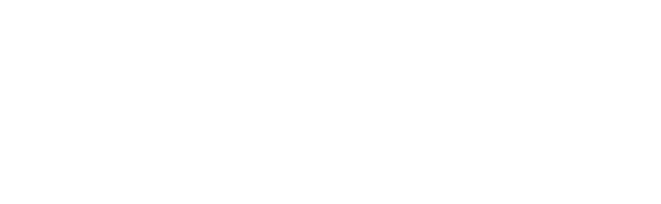


One-to-One Computing and Student Achievement in Ohio High Schools

\author{
Nancy L. Williams
}

I hereby release this dissertation to the public. I understand that this dissertation will be made available from the OhioLINK ETD Center and the Maag Library Circulation Desk for public access. I also authorize the University or other individuals to make copies of this dissertation as needed for scholarly research.

Signature:

\begin{tabular}{lc}
\hline Nancy L. Williams, Student & Date
\end{tabular}

Approvals:

Dr. Karen H. Larwin, Dissertation Advisor Date

Dr. Robert J. Beebe, Committee Member

Date

Dr. M. Kathleen L. Cripe, Committee Member

Date

Dr. Salvatore A. Sanders, Committee Member

Date

Dr. Salvatore A. Sanders, Associate Dean of Graduate Studies

Date 
Nancy L. Williams

2014 


\begin{abstract}
This research explores the impact of one-to-one computing on student achievement in Ohio high schools as measured by student performance on the Ohio Graduation Test. The study sample includes 24 treatment schools that are individually paired with a similar control school. The 1:1 programs in treatment schools have been in place for one to four years using various devices including laptops, netbooks, and iPads. An Interrupted Time Series methodology was deployed to examine OGT data over a period of five to eight years depending on how long the 1:1 program had been in place.

Overall student performance and content specific achievement in math, reading, science, social studies, and writing are not significantly affected by the introduction of 1:1 computing when analyzed using IPD meta-analysis. When broken down by the longevity of the 1:1 program, consistent patterns did not emerge for any of the four time clusters that were examined using linear regression or meta-analysis. However, there are instances of the treatment group significantly outperforming the control group in one content area for one time cluster. These same findings hold true across demographic subgroups including gender, race, disability status and economic status. Patterns are not evident when studying the sample by time cluster for the various demographic subgroups; however, students with disabilities in the control group performed significantly higher that than their peers in the treatment schools for time clusters 1 and 4.

Treatment schools, using a netbook device for their 1:1 program, produced the greatest overall change in scores (pre-treatment vs. treatment period) when compared to the other devices being used. Although statistically significant, the gain in test scores is very small.
\end{abstract}


Keywords: implementation fidelity, iPad, laptop, mobile learning, netbook, one-to-one computing 


\section{Acknowledgements}

"What you get by achieving your goals is not as important as what you become by achieving your goals." Zig Ziglar

My goal of earning a Doctoral degree would not have been possible without the love, support, and guidance of many people. I would like to thank the following individuals for not only helping me to achieve this goal, but more importantly, for inspiring me to grow as a person and educational leader in the process.

Dr. Karen Larwin graciously served as my dissertation chair and provided knowledge, guidance, support, and advocacy throughout the entire program. I am especially appreciative of her patience, willingness to answer my questions, perseverance as I worked through the details, and the many hours she spent helping me analyze data.

Dr. Beebe, Dr. Cripe, and Dr. Sanders provided valuable feedback and constructive criticism throughout the dissertation process as committee members, broadened my perspective as a researcher, and improved the quality of this dissertation. The advice and expertise provided by Leslie Reedy as she edited the document where also greatly appreciated and a vital component in the writing process.

I would also like to thank my family and friends for their love and support throughout the doctoral program. In addition to her care and support, my mom spent numerous hours reading OGT results to me to expedite the data entry procedure. I am especially thankful to my sister, Amy, for her interest and encouragement and to Mary Rose Walker for the opportunity to share my ideas and frustrations during the many conversations we had on her way to work each morning.

I would also like to acknowledge the prayers and affirmation that were provided by the six members of my disciple covenant group at Jefferson United Methodist Church, 
the inspiration provided by Rev. Dr. Dan Bilkert and Dr. John Patterson, and the care provided by the entire congregation. Praise God for his many blessings!

Lastly, I have to mention that although he has passed on to another world, my dad, a YSU alumnus and Penguin fan, would savor this moment and be smiling from ear to ear as he bragged to his friends about his daughter earning her Doctoral degree from Youngstown State University. 


\section{TABLE OF CONTENTS}

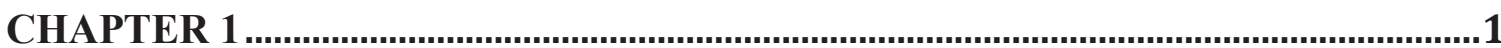

Statement of the Problem.........................................................................................

1:1 Computing Program Goals ..............................................................................

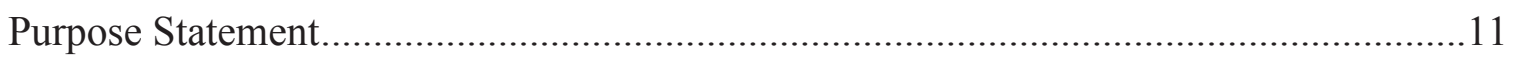

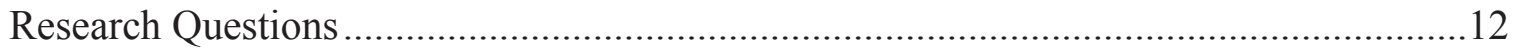

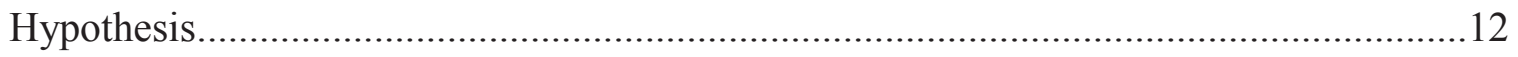

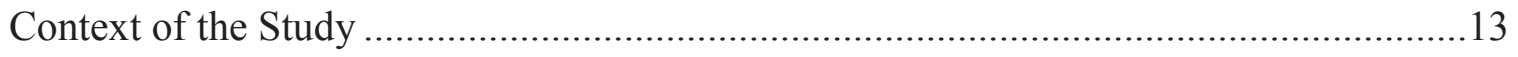

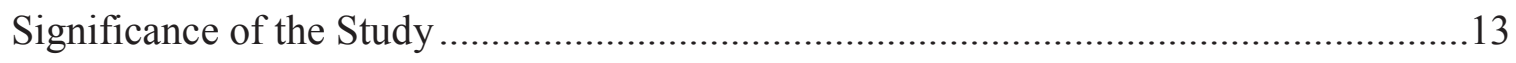

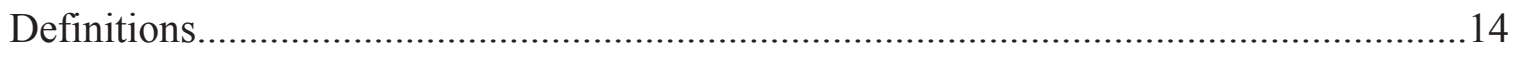

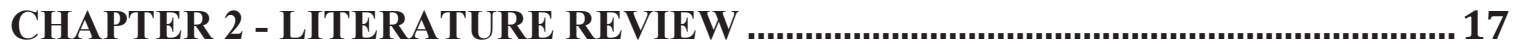

Student Engagement and Student Achievement .................................................... 18

One-to-One Computing and Student Engagement ...................................................20

One-to-One Computing and Student Achievement .....................................................23

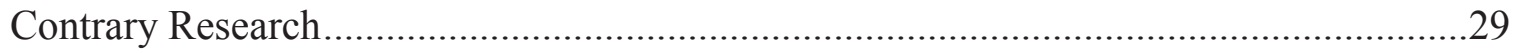

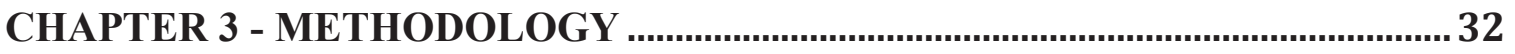

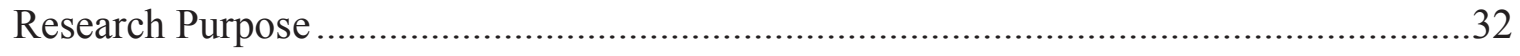

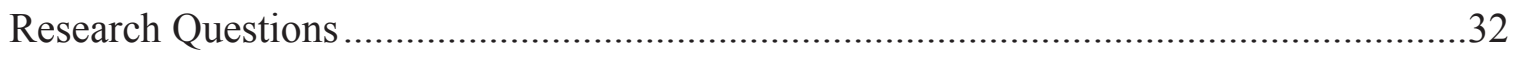

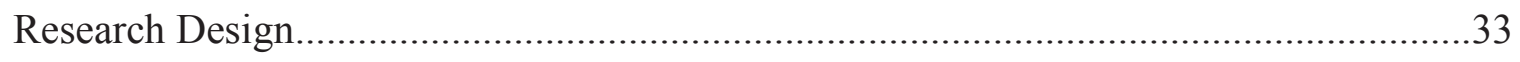

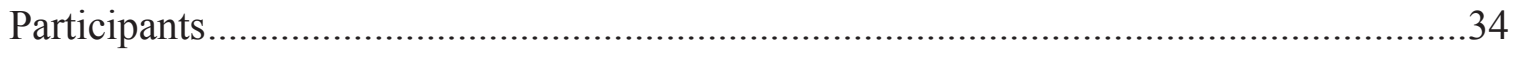

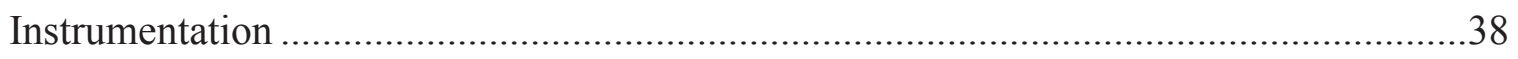

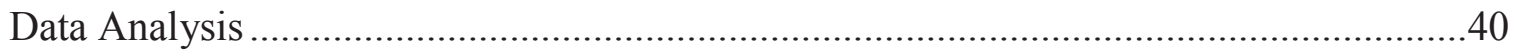

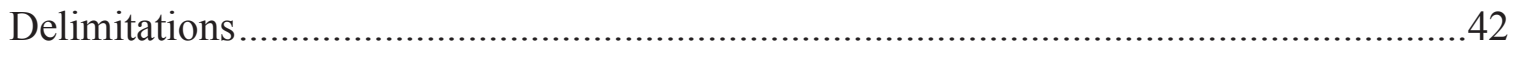


CHAPTER 4 - RESULTS

Descriptive Analysis

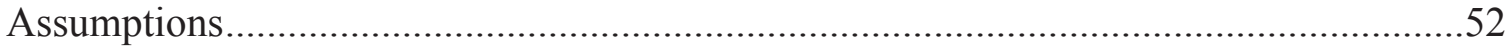

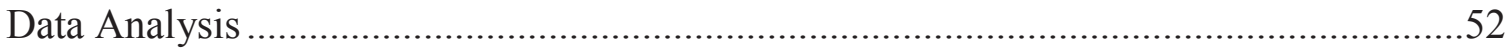

Overall achievement using performance index scores.......................53

Content area achievement using mean scaled scores......................... 55

Achievement disaggregated by subgroup.............................66

Achievement broken down by 1:1 computing device...................... 66

Additional Findings..................................................... 68

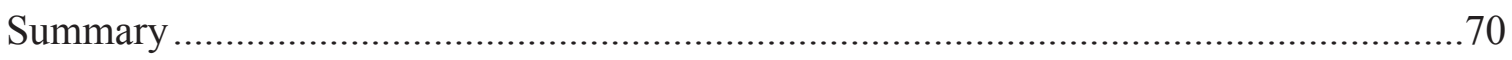

CHAPTER 5 - DISCUSSION

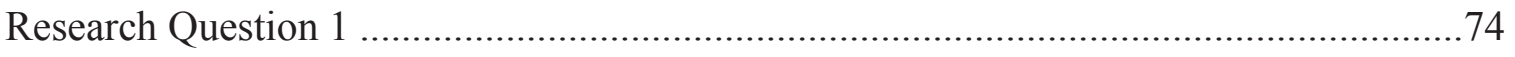

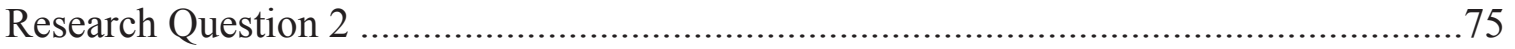

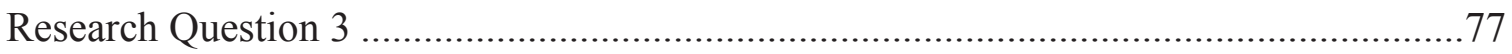

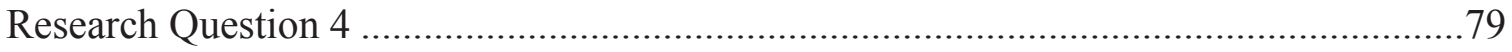

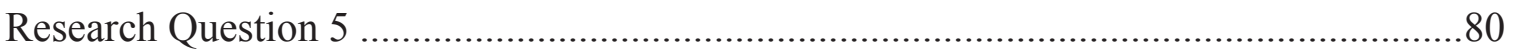

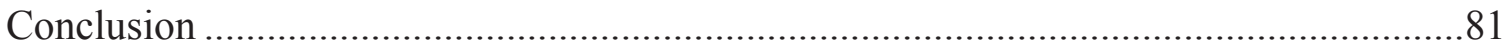

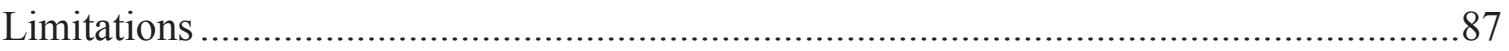

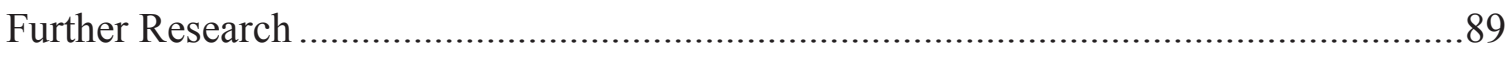

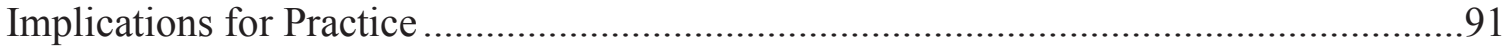

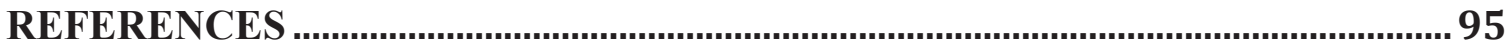

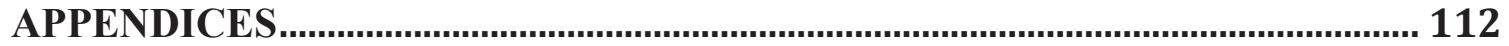




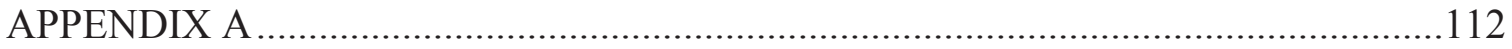

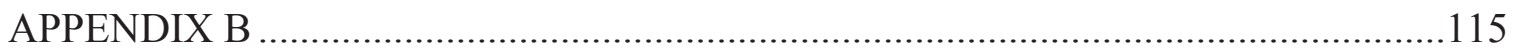

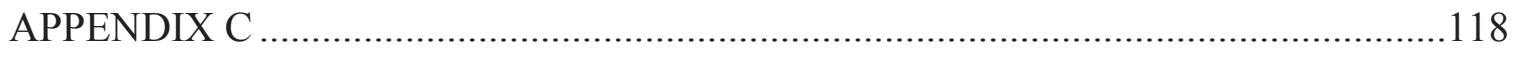

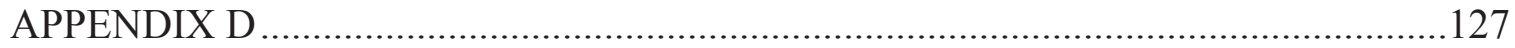

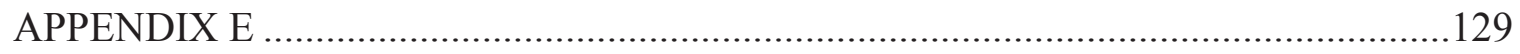

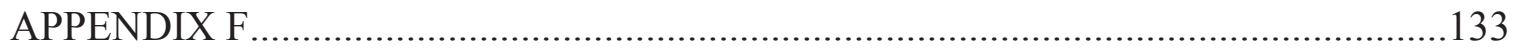

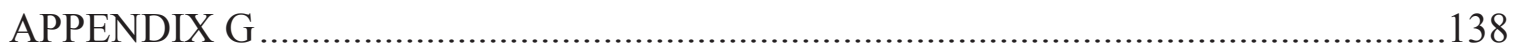

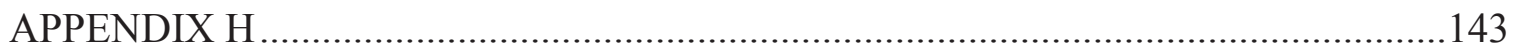

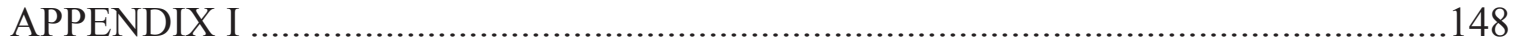

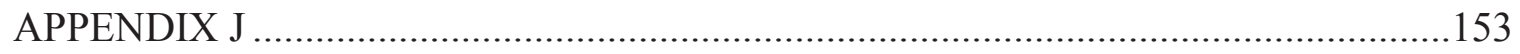

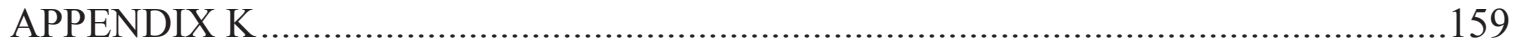

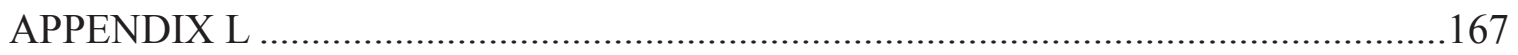

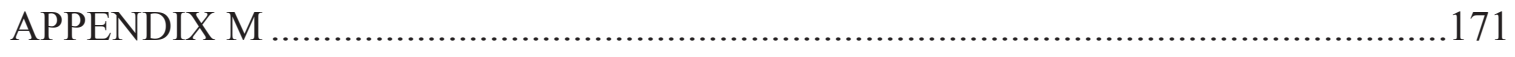

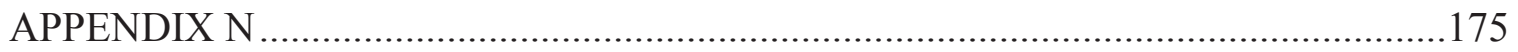

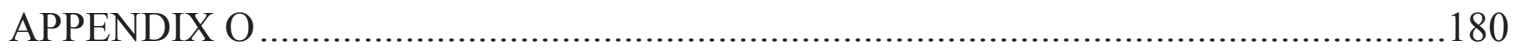

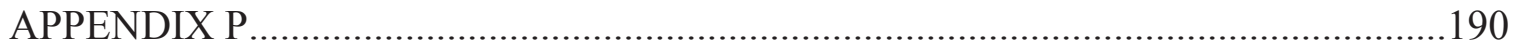

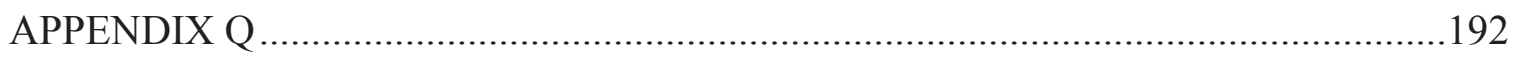




\section{Chapter 1}

\section{Statement of the Problem}

Public school districts entered the age of accountability with the enactment of No Child Left Behind in 2001. Standardized tests were required for several grade levels, test scores began to be published on annual report cards, and each district and school was given an overall performance rating in one of five designations ranging from excellent to academic emergency in the state of Ohio. Since then, accountability has continued to increase with respect to student performance within each learner subgroup as well as the overall population, and fiscal accountability measures are slated to be added to district report cards in Ohio in 2014. As school districts are faced with pressure to increase student achievement and with dwindling financial resources from the state, it is essential that they invest in instructional resources that maximize student learning, effectively address the academic content standards, appropriately prepare students for work in the $21^{\text {st }}$ century and efficiently use district financial resources. As one examines the current state of technology with regard to accessibility, mobility, and affordability, along with recent legislative changes in Ohio regarding academic content standards and assessment, there appears to be a unique window of opportunity for districts to consider

implementation of a one-to-one (1:1) computing program. Financial resources that would normally be used to purchase textbooks aligned to the new standards and to upgrade technology in preparation for the transition to online testing for the 2014-15 school year could, instead, be used to institute a 1:1 computing program. 


\section{Historical Context}

Schools began to acquire computers in the late 1970s following the invention of the personal computer in 1975. Schools often purchased only one or two computers and placed them in the library for staff use. After a few years, schools created labs of 25 standalone computers so an entire class of students could use them at once, primarily to play educational games loaded onto the computer via a floppy disk. As low-cost, highspeed networks came into existence in the late 1980s, the preferred model shifted first to networked labs and then to multiple (4-5) computers placed in each classroom, especially at the elementary level (Dede \& Richards, 2012). Laptop computers were introduced to the industry in 1984 as equipment continued to improve with regard to processing speed and storage while decreasing in size. The Internet became available to the public in 1995 thereby opening up the possibility for use in K-12 educational settings. Wi-fi, or wireless connection to the Internet, became a reality in 1999 and led to the computer on wheels delivery model where multiple laptops were available on a mobile cart that could be rolled into the classroom for short term use. As laptops became smaller and more powerful, handheld devices started to emerge in the form of personal digital assistants and tablets, and cell phones became smartphones with Internet access. A fourth technology delivery model, 1:1 computing, emerged as each student possessed his or her own device to use at school and home. The prevalence of mobile, handheld devices has exploded in the past five years with the invention of touch screens and decreasing prices. Along with rapid growth in the number of students owning a personal, handheld device came a fifth technology delivery model known as bring your own device (BYOD) where students used their own equipment to access the school network. 
The first 1:1 program began in 1989 at the Methodist Ladies College in Melbourne, Australia, with the school requiring all incoming students in grades five through 12 to purchase a school approved Toshiba laptop (Russell, Bebell, \& Higgins, 2004). Initial experiments with 1:1 computing in America took place in 1996 when the Microsoft Corporation launched the Anytime Anywhere Learning Project in partnership with Toshiba America Information Systems' Notebooks for Schools. During the inaugural year of the project, laptops were provided to every student in 16 public schools (Gulek \& Demirtas, 2005). Sponsorship of 1:1 programs moved from the private to the public sector as individual schools, districts, and eventually states began to fund 1:1 laptop pilot programs. The first two states to implement pilot programs were Georgia and Maine, in 1999 and 2000 (Dede \& Richards, 2012). As of 2011, 11 states had 1:1 laptop initiatives in place and over 2000 schools throughout the United States had 1:1 laptop programs in a full grade or throughout the school (Greaves, 2012).

\section{Technology Delivery Models - Why 1:1 Computing?}

As indicated earlier, schools deployed several different models as they implemented technology with students, including the following models:

- Lab - separate room with multiple computers (most generally a classroom set);

- Multiple computers located inside the classroom;

- Rolling cart - mobile devices (laptops or tablets) on a cart that comes to the classroom;

- $1: 1$ - each student is provided with their own mobile device (sometimes permitted to be taken home); and 
- Bring your own device - students bring their own mobile device to use at school.

For computers to have a positive impact on learning, they need to be seen as tools that are an integral part of the educational process and utilized on a consistent basis. Soloway, Norris, Blumenfeld, Fishman, Krajcik, and Marx (2001) found that very few students were using computers in K-12 schools despite having computer labs in their school. Teachers report that when computers are in labs, technology is less frequently used for instruction because of the difficulty of scheduling time in the lab and transporting students there (Adelman, Donnelly, Dove, Tiffany-Morales, Wayne, \& Zucker, 2002). "As long as computer labs are down the hallway and up the stairs, teachers will consider them irrelevant to learning and teaching" (Soloway et al., 2001, p. 16). Computers are used more frequently by students when they are readily accessible in the teacher's own classroom (Becker, Ravitz, \& Wong, 1999). Increased student use of computers has a strong positive correlation to gains in student learning (Marx, Blumenfield, Krajcik, Fishman, Soloway, Geier, \& Tal, 2000).

Moving multiple computers into the classroom, a common practice in Ohio elementary schools starting in the late 1990s, increased accessibility and usage but did not attain the ideal of making computers an integral part of the educational process. With a student-to-computer ratio of 5:1, teachers found the effort to use them simply too high, given all that needed to be accomplished in a school day (Soloway et al., 2001). A study conducted by Lowther, Ross, and Morrison (2003) compared the impact of a five computer per classroom model to a 1:1 model in 21 classrooms in grades five through seven. They found student achievement on locally administered assessments in writing 
and problem solving to be significantly higher for students in the 1:1 model with a strong influence on students' writing with effect sizes of .90 to 1.47 .

As computers became mobile and were placed on rolling carts, schools tried to combine the convenience of having computers in the classroom with improved accessibility to students with a smaller ratio of either 2 or 1:1. When comparing the impact of computers on carts (1:1 ratio) with 1:1 computing where students had personal access to the devices 24/7, Russell et al. (2004) found several advantages of the personal 1:1 computing model including greater use across the curriculum, more use of technology at home for academic purposes, less large group instruction, and nearly universal use of technology for writing. A recent study compared three different technology delivery models, (a) class sets of iPads were retained in the school and issued to students for particular lessons, (b) iPads were issued to all students but stayed at school, and (c) iPads were issued to all students and taken home daily. Researchers concluded personal possession of the device with $24 / 7$ access was "the single most important factor" for successful use of the technology to impact learning (Burden, Hopkins, Male, Martin, \& Trala, 2012, p. 9).

The most recently deployed model, BYOD, has many of the same advantages as 1:1 computing but presents additional challenges regarding implementation. The most frequently cited concern with BYOD programs is network security. These programs often include the use of cell phones which can get around network security by using a $3 \mathrm{G}$ or $4 \mathrm{G}$ connection rather than going through the filtered school Wi-fi connection. This model also requires additional technical support and teacher training since many devices are being used rather than just one. Teachers, in particular, have noted the potential that 
BYOD has to widen the achievement gap as students without their own devices (often the economically disadvantaged students) are not afforded the opportunity to use this learning tool and may, in fact, be "left behind" (Netgear, 2013).

As long as computers are not readily at hand, available only at school, they will not become an integral part of the educational process. Despite a dramatic increase in the presence of computers in schools over the past three decades, student use has been relatively stagnant, perhaps because student-to-computer ratios have not yet reached a stage at which the technology is pervasive or ubiquitous (Bull, Bull, Garofolo, \& Harris, 2002). The 1:1 technology delivery model has the best chance of reaching a ubiquitous level as indicated by Soloway et al. (2001): "K-12 will take computing technologies seriously only when they are as available as pencils" (p. 20).

\section{1:1 Computing Program Goals}

As districts or schools implement 1:1 computing programs, they commonly cite one or more of following goals:

- Improving academic achievement;

- Increasing equity of access;

- Transforming the quality of instruction; and

- Increasing the economic competitiveness of the region by preparing students for work in the $21^{\text {st }}$ century (Penuel, 2006).

All four goals are interrelated, and achieving one will impact the remaining three. In light of the overall purpose of education and the current laser-like focus on accountability, increasing student achievement is the ultimate goal for implementing 1:1 computing (Zucker, 2004). 


\section{Current Circumstances - A Unique Window of Opportunity to Implement 1:1}

\section{Computing}

Recent trends regarding the accessibility, mobility, and affordability of technology, coupled with legislative action requiring schools to put more rigorous academic standards into practice and administer state assessments online, may create the tipping point needed for Ohio school districts to adopt 1:1 computing programs.

Accessibility to equipment and the Internet. In the late 1980s, schools began to focus on reducing the ratio of students to each computer as this ratio became the accepted proxy measure of students' access to computers (Russell et al., 2004). Believing that increased access to computers would lead to increased usage and improved learning, educational leaders purchased increasingly larger numbers of computers to significantly reduce the ratio. The ratio for K-12 schools in the United States has dropped from 125:1 in 1983, to 9:1 in 1995, 6:1 in 1998, 4:1 in 2002 (Technology Counts, 2003) and 3:1 in 2010 (Gray, Thomas, \& Lewis, 2010).

Just as the availability of equipment has increased drastically over the past 30 years, so has student access to the Internet at school and home. The National Center for Educational Statistics (2010) indicates that all public K-12 schools in the United States have access to the Internet, which is a significant increase from the $8 \%$ that had access in 1995 and the $77 \%$ that had access in 2000 . Student access to the Internet at home has held steady since 2006 with $6 \%$ of the student population not having any access, while access via handheld devices has increased significantly.

Mobility. Technological advances, such as handheld and mobile devices, directly affect the way people live in this information age. As these technologies become more 
prevalent, their integration into everyday living has become an essential skill for students to be successful in their future and is a vital part of the knowledge and skills that students should master prior to graduation according to the Partnership for Education in the $21^{\text {st }}$ Century (n.d.). This rapid growth in mobile technology has sparked interest in the use of laptops, tablets, handheld devices, and smartphones as an instructional tool to improve student learning. In the national Speak Up survey of students conducted in 2012 by Project Tomorrow, $80 \%$ of high school students indicated that they are smartphone users, $73 \%$ own a laptop, and $48 \%$ have some type of tablet for their personal use. The report describes student ownership of mobile devices as "continuing at a dizzying pace" (Project Tomorrow, 2013, p. 4). Schools provide $27 \%$ of the students with laptops and $14 \%$ with tablets, but severely restrict use of personal devices (only $18 \%$ of seniors could use their personal laptops at school despite $73 \%$ of them owning them).

Not only do a growing number of students own and use mobile and handheld computing devices, the devices have improved dramatically over time. Compared to early versions, laptop computers today have $500 \%$ longer battery life, their weight has dropped $80 \%$, the screen resolution has improved $400 \%$, and the total cost of ownership is down $70 \%$ (Greaves, 2012). Other mobile devices, such as tablets and smartphones, are undergoing similar evolutionary changes. These improvements in equipment and mobility provided the impetus for many schools to adopt 1:1 computing programs. On the most recent Biennial Educational Technology Assessment (BETA), 62 Ohio schools (3\%) reported having a 1:1 computing program with student access to a device 24/7 (eTECH Ohio, 2012). This is slightly below the national average of $6 \%$ overall and $13 \%$ for secondary students (Gray et al., 2010). 
Affordability. Moore's Law, in its original form, predicted that the number of transistors in a computer would double every 18 months (Zucker, 2004). The law has been extrapolated to other aspects of computing including processing speed, storage, networking, and cost (as an inverse relationship). One example of its bearing on cost can be found when comparing the cost of the first Macintosh portable computer sold in 1991 for $\$ 7300$ (1.4 MB) to a Chromebook selling in 2013 for $\$ 199$ (16 GB with $100 \mathrm{~GB}$ of cloud storage). As devices become increasingly more powerful and affordable, so do software and networking equipment. In a recent study, the cost differential for a school to move from a 3:1 student to computer ratio (national average) to a 1:1 ratio would be \$131 per student per year (Greaves, Hayes, Wilson, Gielniak, \& Peterson, 2010). This calculation includes the cost of technical support, professional development, and software as well as the projected savings for reduced copying and paperwork. With $67 \%$ of public school districts reporting they have a technology replacement plan in their annual budgets (Gray \& Lewis, 2009), districts could reallocate money that was set aside to replace existing equipment (desktops located in labs in most cases) with mobile devices to implement a 1:1 initiative.

Content standards. With the adoption of new academic content standards in the four major content areas, districts are searching for new materials, tools, and instructional strategies to ensure student mastery of these more rigorous outcomes. The transition to new standards provides a window of opportunity for districts to consider the use of technology and electronic resources to deliver content, actively engage students in learning, and impact student achievement before spending thousands of dollars on traditional textbooks that have been revised to align with the new Common Core 
standards in English Language Arts and mathematics, and the Ohio Revised Academic Standards in science and social studies. At an average cost of $\$ 85$ per textbook at the high school level, forgoing new textbooks and using up-to-date, free online resources to meet the new standards could significantly offset the additional annual cost of \$131 per student. The Lorain City School District recently reported saving \$140,000 by issuing netbooks with digital content to all students in grades six through 12 rather than replacing printed textbooks (McLester, 2011).

Free online resources are readily available and frequently organized by content standard and grade level, including resources such as the Ohio Model Curriculum for various content areas (Ohio Department of Education, [ODE], 2011) and the Core Collection of Electronic Resources available on the INFOhio web site (Management Council of the Ohio Educational Computer Network, 1994). The National Science Digital Library (n.d.) publishes a web page with thousands of links to open source educational resources arranged by content area, standard, grade level, resource type, and instructional strategy. Other web sites such as Khan Academy (Khan, 2006) or Center for Applied Special Technology ([CAST], 1984) are organized by topic and would require the teacher to choose appropriate lessons for each standard. The aforementioned sites are updated on a regular basis and add resources to their collection of free instructional materials.

Online assessments. Another factor driving districts to consider a transition to 1:1 programs is Ohio's plan to begin administering state academic assessments online in the 2014-15 school year. Schools will be expected to provide the technology resources needed to administer the state achievement tests to all students within a specified period 
of time. In many cases, schools will solve this issue by rotating students through labs with enough computers for the whole class to take the test at once. Rather than expending money to augment computers in a lab setting, or adding another lab to meet the time restriction, schools could reallocate money to purchase mobile devices that meet the state testing specifications.

All five of these factors (increased accessibility, mobility, and affordability of technology, the implementation of new standards, and online assessments) are coming together to create a unique window of opportunity for schools to adopt a 1:1 computing program.

\section{Purpose Statement}

The purpose of the study is to evaluate the effect that 1:1 computing programs have on student achievement in Ohio high schools. It is a quantitative study using an Interrupted Time Series (ITS) design to graphically analyze the influence that 1:1 programs have on student achievement on the Ohio Graduation Test over several years of implementation. Significance testing was conducted using individual participant data (IPD) meta-analysis for overall student achievement using performance index scores and for content specific differences in achievement in writing, reading, mathematics, science, and social studies using scaled scores. Data were also examined to compare results for laptop (not brand specific) and tablet devices, to explore the relationship between the length of the program and its impact on student achievement and to determine any differences between various demographic groups. 


\section{Research Questions}

This study attempts to answer the following research questions about 1:1 computing and student achievement:

1. Does implementation of a 1:1 computing environment in Ohio high schools affect student achievement?

2. Does the effect of 1:1 computing, as measured by test scores on the Ohio Graduation Test (OGT), vary by content area including math, reading, science, social studies, and writing?

3. Does the longevity of the 1:1 program influence the effect it has on student achievement?

4. Does the effect of 1:1 computing vary by demographic group?
a. Gender;
b. Race;
c. Disability status; and
d. Economic status.

5. Does the type of device used by the students (laptop, netbook, or tablet) influence the effect 1:1 computing has on student achievement?

\section{Hypothesis}

High school students have grown up in a digital age, are proficient at using technology in their daily lives for personal use, and have the capacity to use technology as a tool to enhance learning when given the opportunity to do so. Properly implemented, 1:1 computing will create the conditions necessary for technology to 
become ubiquitous and will positively impact learning. It is hypothesized that student achievement will be greater when students learn in a 1:1 computing environment.

\section{Context of the Study}

The study takes place in Ohio high schools that have implemented a 1:1 computing program for at least one year and for no more than four years corresponding to implementation dates between August 2009 and August 2012. Student achievement is measured using the initial administration of the Ohio Graduation Test (OGT) which is given to sophomores during the second week of March each year.

\section{Significance of the Study}

In the current age of accountability, school administrators and boards of education need to provide instructional resources for students and staff that will have the greatest impact on learning while demonstrating fiscal responsibility in a challenging economy. The current investigation provides critical information regarding the effect 1:1 computing has on student achievement in Ohio high schools. As Ohio districts make the transition to new content standards and online assessments in the next two years, they will be forced to re-evaluate instructional resources. The public demands that each district weigh the cost and potential benefit of any capital outlay or purchase of materials or services prior to making a commitment to purchase these items. One-to-one computing can help districts fulfill several goals in addition to improving student achievement. However, the impact that 1:1 computing has on student achievement is a critical piece of information for school district personnel as they carry out the decision-making process using a costbenefit analysis. 
A number of previous studies examined the impact of 1:1 laptop programs primarily at the middle school level. The majority of these studies focused on intermediate outcomes such as teaching practices, professional development, student use of the computers, and student engagement (Zucker, 2004). Although a few studies have been completed regarding the impact of 1:1 computing on student achievement, they concentrate on student performance in mathematics and language arts (reading and writing) with little information on their impact in science and social studies. There are few studies of 1:1 laptop programs in a high school setting, but none that specifically evaluate student achievement in this setting. Currently, there are no known studies published regarding the effect 1:1 iPad programs have on student achievement. Therefore, the current investigation adds knowledge to the literature regarding 1:1 computing in the high school setting, offers new insight into the bearing such programs have on science and social studies achievement, and provides critical information to local decision-makers regarding instructional materials and technology.

\section{Definitions}

Chromebook - a new type of laptop/notebook that runs Google's cloud-based Chrome

OS as an operating system. It looks and feels like a small, thin laptop (screen - 11.6 inches, thickness - .7 inch, weight -2.4 pounds), has similar features, but is designed to be used while connected to the Internet, utilizes Google products exclusively, including Google Chrome as a browser, Gmail, and Google drive. Apps reside on the Web rather than the machine itself (Google, 2013). 
$i P a d$ - a specific brand of tablet that is sold by Apple and uses the iOS operating system.

The device has a multi-touch screen, front and rear facing cameras, and a high resolution display, but no hard keyboard or external ports (Apple, 2013).

Laptop - a portable personal computer that fits in a person's lap, consists of a clamshell structure that opens to reveal a screen in the upper part and a keyboard in the lower part, a web camera mounted on the inside of the top shell, an internal microphone, and can run on battery power (Webopedia, 2013). Laptops can also be called notebooks (Phatak, 2012).

Mobile learning - the acquisition of skills and/or knowledge, in any content area, that takes place as a result of the learner interacting with portable technologies (Nedungadi \& Raman, 2012).

Netbook - a laptop that is smaller than a notebook and comes with a limited number of features (no CD or DVD drive). The physical size and computing power are what distinguishes it from a notebook (Phatak, 2012).

Notebook - a laptop designed for increased mobility. Notebooks typically weigh less than six pounds and fit in a briefcase (Webopedia, 2013). The terms laptop and notebook are frequently used interchangeably (Phatak, 2012).

One-to-one (1:1) computing - a learning environment where the teacher and all students are provided with a wireless mobile computing device for their personal use at school and home 24 hours a day, 7 days a week during the school year (Penuel, 2006). Devices can include laptops, netbooks, chromebooks, tablets, or smartphones. 
Tablet - a wireless, flat, one piece mobile personal computer with a touch screen interface to replace the mouse and keyboard found on laptops. Tablets are frequently equipped with a camera and microphone and utilize downloaded apps to perform specific tasks (Tech Target, 2013). They are typically smaller than a notebook but larger than a smartphone. Some examples of tablets are the iPad, Kindle Fire, and the Samsung Galaxy Tab.

Ubiquitous computing - a situation is which technology is everywhere and is used all the time. It is the ultimate target of one-to-one computing where the use of technology becomes so widespread and continuous that people use it without thinking about it. Use of the device is so commonplace that it essentially becomes invisible to the user (Lei, 2010b). 


\section{Chapter 2}

\section{Literature Review}

High school students are considered digital natives as they have grown up with technology readily accessible to them for personal use. As these students arrive at school each day, they are frequently told to "power down" and leave mobile devices turned off and in their locker. Technology has become ubiquitous for students outside of school and has the potential to be used as a tool to improve learning inside the walls of the school building. Handheld devices, in particular, can be used to increase student engagement in the learning process and ultimately impact student achievement. In a 1:1 computing environment, each student is provided with his or her own mobile device with $24 / 7$ access to use at school and home. One intermediate target of 1:1 computing is to increase student engagement, while the ultimate goal is to improve learning.

The purpose of this dissertation is to determine the impact that 1:1 computing has on student achievement at the high school level. Studies on student engagement reveal a link to high yield instructional strategies and student achievement. Research on 1:1 computing programs tend to focus on student engagement, with few studies taking place at the high school level. The few studies that analyzed the impact of $1: 1$ programs on student achievement were conducted using laptops in intermediate or middle schools. This is one of the first studies to examine the effect that 1:1 computing programs, including iPad programs, have on student achievement at the high school.

The review of the literature is divided into four sections. The first section identifies the literature on student engagement, highly engaging instructional strategies, and the link to student achievement. The second section examines the literature on the relationship between 1:1 computing and student engagement; Part three looks at the 
literature on 1:1 computing and student achievement, overall, and then by content area and demographic groups, and the final section examines contrary research and some of the explanations for the alternative findings that are given in the literature.

\section{Student Engagement and Student Achievement}

A comprehensive definition of student engagement typically includes three

components, (a) behavioral engagement, (b) cognitive engagement, and (c)

motivational/emotional engagement. The behavioral component is split into academic engagement encompassing such measures as time on task, credit accrual or homework completion, and behavioral engagement which includes attendance, voluntary classroom participation, and extracurricular involvement. The second component, cognitive engagement, describes students' investment in the actual learning process, not just observable behaviors, but internal investment where the mind is engaged in classroom work. The third component, motivational/emotional engagement, describes the degree to which students see the value of what they are doing in school (Yazzie-Mintz \& McCormick, n.d.).

Researchers frequently use only one or two of these components when designing a study and measure each component in different ways. Student engagement has been described as the "engine for learning" (Reeve, 2006, p. 658) and is frequently expressed using terms such as interest, on-task behavior, enjoyment, involvement, active participation, and motivation, while disengagement is described as boredom, apathy, disaffection, or lack of interest. Students that are engaged show sustained behavioral involvement in learning activities, are more willing to persist at challenging tasks, and often display a positive tone toward their work (Skinner \& Belmont, 1993). 
Existing studies consistently demonstrate a strong positive relationship between student engagement and academic achievement (Appleton, Christenson, \& Furlong, 2008; Furrer \& Skinner, 2003; Klem \& McConnell, 2004; Marks, 2000). Pintrich and DeGroot (1990) found a positive link between motivation and overall academic performance. Students who are more engaged in school earn better grades (Carini, Kuh, \& Klein, 2006) and higher scores on standardized tests (Skinner, Wellborn, \& Connell, 1990). The positive link between engagement and performance holds true across diverse populations (Finn \& Rock, 1997) with academically successful students reporting greater engagement in school than their peers.

High levels of student engagement are closely associated with specific instructional strategies. These strategies have been described as high yield instructional strategies (HYS) because of their effect on student achievement. When studying high school classrooms, Shernoff, Csikszentmihali, Schneider, and Shernoff (2003) discovered that student disengagement stems from a lack of meaning or challenge that frequently occurs when teachers use a lecture format. Additional studies confirm that the use of a lecture strategy provides little opportunity for students to be engaged and learn the material for themselves (Mitchell, 1993). As teachers move away from lecture and implement more student-centered instructional strategies, student engagement and interest increase dramatically.

When students are given the chance to work in small groups, they display greater concentration, interest, and engagement (Shernoff et al., 2003). As students collaborate and begin to work cooperatively in small groups, they become more motivated (Johnson \& Johnson, 1998) and produce greater student achievement (Slavin, 1989). Cooperative 
learning was identified as one of the nine high yield instructional strategies when Marzano, Pickering, and Pollock (2001) conducted a meta-analysis to determine which strategies have the greatest impact on student achievement. Cooperative learning yielded a large effect size of .74 on student achievement.

Another highly engaging strategy that has a significant impact on student performance is the use of project-based learning (PBL). It includes a set of learning experiences and tasks that guide students in inquiry toward answering a central question, solving a problem, or meeting a challenge. Among the benefits of this strategy are increased student motivation and engagement, and higher standardized tests scores (Larmer, 2009). Generating and testing hypotheses, one of the expectations of PBL, was also identified as a high yield strategy by Marzano et al. (2001) with an effect size of .61 on student achievement.

Students taking the High School Survey of Student Engagement indicated that discussion and debate, group projects and projects/lessons involving technology were the most engaging classroom activities, while lessons in which the teacher lectured were the least engaging (Yazzie-Mintz \& McCormick, n.d.).

\section{One-to-One Computing and Student Engagement}

Based on the definition of student engagement discussed earlier, there are several ways to evaluate student engagement in schools. Several studies utilized quantitative measures of attendance and behavior to determine the effect of 1:1 computing on student engagement. Following the deployment of a 1:1 laptop program with all middle school students in Maine, Holcomb (2009) reported a 7.7\% increase in student attendance. College students participating in a 1:1 tablet program also displayed better attendance 
rates (Enriquez, 2010). As a result of the Maine Learning Technology Initiative, student engagement appeared to increase as disciplinary referrals to the office decreased by $54 \%$ (Lemke \& Martin, 2003), and a pattern of reduced behavioral referrals continued after that (Muir, Knezek, \& Christensen, 2004). Students were sent to the office less frequently and suspensions decreased as a result of the Texas Immersion Pilot involving 21 middle schools (Shapley, Sheehan, Maloney, \& Caranikas-Walker, 2010). A 1:1 laptop program that involved 1000 ninth and tenth grade students in Alabama similarly contributed to a decline (29\%) in school-wide discipline problems (Intel Inc., 2008).

Numerous research studies on 1:1 computing programs report increased engagement, motivation, interest, or student participation based on survey data. Two studies used validated survey scales; one showed a statistically significant impact on motivation when high school students used laptops (Trimmel \& Bachmann, 2004), and the other yielded a statistically significant difference in engagement with elementary students in a 1:1 laptop program (Russell et al., 2004).

Using teacher perception surveys, researchers reported increased student engagement or motivation in several 1:1 laptop programs (Bebell \& Kay, 2010; Dawson, Cavanaugh, \& Ritzhaupt, 2008; Corn, 2009; Shapley et al, 2010; Lowther, Strahl, Inan, \& Bates, 2007) as well as 1:1 iPad programs (Burden et al., 2012; Heinrich, 2012; Enriquez, 2010). Teacher interviews and classroom observations indicated that student participation increased in classes using laptops (Bebell \& Kay, 2010; Hegedus \& Kaput, 2004), and students were more persistent in completing school work (Mouza, 2008). Silvernail and Lane (2004) reported that students with special needs became more engaged and actively involved in their own learning, while the Mitchell Institute (2004) found the same to be 
true for at-risk, low achieving students. Student surveys consistently revealed higher levels of engagement and increased interest in learning (Bebell \& Kay, 2010; Lowther et al., 2007; Silvernail \& Lane, 2004).

As researchers examined teaching practices in 1:1 classrooms, they learned that teachers using laptops were more likely to use highly engaging instructional strategies than traditional classroom teachers. Teachers leading 1:1 classrooms were less likely to lecture when using laptops (Lowther, Strahl, Zoblotsky, \& Huang 2008; Rockman, 2000, 2003; Russell et al., 2004). While conducting research on a 1:1 laptop program for grades five through seven, Lowther et al., (2003) found a significant increase in student-centered instructional strategies in laptop classrooms when compared to non-laptop classrooms. Cooperative learning structures were more prevalent in 1:1 classrooms; students spent more time working in small groups, and were engaged in collaborative work more frequently than in traditional classrooms (Amirian, 2004; Bhave, 2002; Dawson et al., 2008; Rockman, 2004; Russel et al., 2004). Classrooms with 1:1 laptop programs also made greater use of project-based learning (Rockman, 2003; Dawson et al., 2008; Mouza, 2008). Berry and Wintle (2009) reported that even though students in Maine found a technology rich project to be more challenging and time consuming than a traditional one, students indicated that the projects were more fun and engaging.

As studies of 1:1 tablet and iPad classrooms are completed, their findings are similar regarding the use of high yield instructional strategies to engage students in learning. Increased student collaboration was a finding in several studies on the use of iPads (Burden et al., 2012; Heinrich, 2012; Henderson \& Yeow, 2012; Garcia \& Freidman, 2011; Manninger \& Holden, 2009). Sonnenberg and Bartelli (2013) also 
reported that lecture time went down, group work went up, and student centered projects increased in middle school classrooms using iPads in a 1:1 environment.

\section{One-to-One Computing and Student Achievement}

Zucker (2004) created a framework for research on 1:1 computing that was broken into three components including (a) critical (input) features of 1:1 computing initiatives, (b) intermediate (implementation) outcomes, and (c) ultimate (impact) outcomes.

\section{CRITICAL FEATURES \\ (Input)}

\begin{tabular}{|l|}
\hline Device used \\
Setting \\
Plan (training) \\
Goals
\end{tabular}

\section{INTERMEDIATE OUTCOMES \\ (Implementation)}

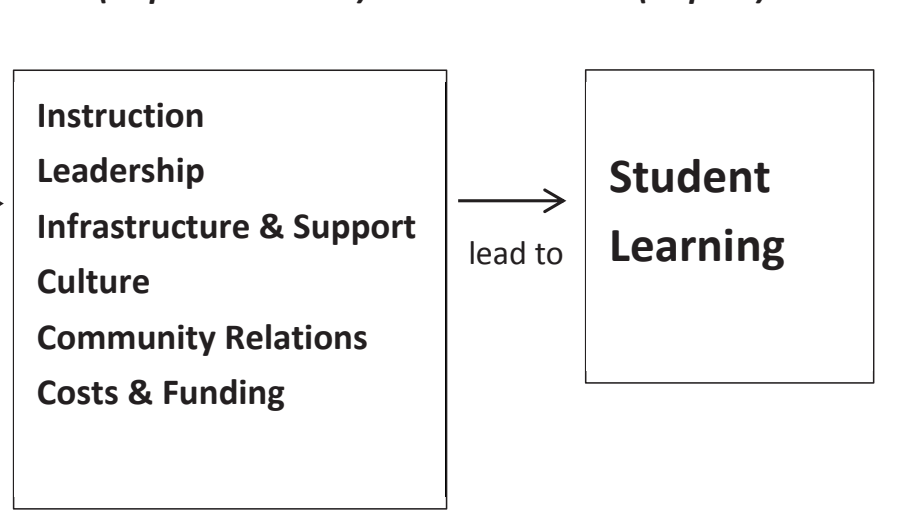

\section{ULTIMATE OUTCOME \\ (Impact)}

Figure 1. A framework for research on 1:1 computing (Zucker, 2004).

Research studies have primarily focused on the input and implementation components of Zucker's research framework. He asserted however, that "increasing student achievement is clearly the most important goal for adopting 1:1 computing" (Zucker, 2004, p. 378).

While numerous studies have examined specific input and/or implementation factors individually, Shapley et al. (2010) created an instrument to measure all of these intervening factors. The study examined student access and use of the laptops, classroom immersion (technology integration, instructional strategies, classroom activities, and communication), and school support (leadership, technical support, and professional 
development). They found that the implementation strength of student access and use (as measured by number of school days students had access to a laptop, the frequency of technology use for learning in core content classes, and the extent of laptop use for homework and learning games) was the only 1:1 implementation factor that yielded a strong relationship to student achievement and consistently predicted student test scores in reading and mathematics. Classroom immersion (as reported by the teachers) and school support were inconsistent predictors of students' achievement test scores.

Since the ultimate purpose of 1:1 computing programs is increased student learning, there are several studies that examined the impact of 1:1 programs on student achievement using various quantitative measures. Several of these studies were associated with the evaluation of large, state initiated 1:1 laptop programs that took place at the intermediate or middle school level.

Overall performance. Grades are one of the commonly accepted ways to measure student performance. Middle school students participating in a 1:1 laptop program earned significantly higher cumulative grade point averages (GPA) following implementation of the program (Lei, 2010a; Lei \& Zhao, 2008) and higher GPAs compared to non-laptop students (Gulek \& Demirtas, 2005; Metiri Group, 2006). Enriquez (2010) reported a significant difference in homework and quiz grades for college students using tablet PCs and a positive, but non-significant, difference in final grades when compared to non-tablet classes.

Writing. "Of the core content areas, some of the most substantial academic achievement results of 1:1 programs have been seen in writing skills" (Sauers \& McLeod, 2012. p. 2). Silvernail and Gritter (2007) found a statistically significant improvement in 
students' scores on the writing section of the Maine Educational Assessment (MEA) between 2000, two years before implementation of the Maine Learning Technology Initiative, and 2005, when schools were in their third year of laptop use. They reported that the average scaled score was 3.4 points higher in 2005 than in 2000 . The 1:1 laptop program had an effect size of .32, indicating an improvement of approximately one-third of a standard deviation. They noted that the number of students attaining the expected score of proficient increased from $29 \%$ in 2000 to $41 \%$ in 2005 . In a related analysis, the researchers found a significant difference between the scores of the students who used their laptops for writing and those that did not. The more students used their laptops for all phases of the writing process, the more likely they were to achieve a proficient score on the MEA. Researchers also discovered that using laptops in the writing process helped students score higher on tests administered in a traditional paper and pencil format as well as those administered electronically.

Middle school students participating in 1:1 laptop programs outperformed their peers on district writing assessments also. Lowther et al. (2003) reported an effect size of .61 when comparing the writing scores of 1:1 laptop students with non-laptop students and also found a significant difference when 1:1 student scores were compared to students learning in a 5:1 environment. Students using laptops in a 1:1 pilot in an affluent California middle school also scored significantly higher on a local writing assessment (Gulek \& Demirtas, 2005). Bebell and Kay (2010) determined that seventh grade students participating in a computer writing study wrote longer responses and achieved higher scores on open ended essays when using their laptops than students responding to the same prompt using traditional paper and pencil. Teachers reported that 
elementary students in New York City showed a dramatic increase in their writing throughout the year as they used their laptops to spend more time on the editing process (Mouza, 2008). Goldberg, Russell, and Cook (2003) also found that secondary students using their laptops to write produced work of greater length and higher quality. The greatest impact came about for students with disabilities.

English language arts. States administer a range of assessments that would fall under this classification including tests in reading, English, language arts, and communication arts. Results indicate that 1:1 programs have a positive effect on student achievement across these different areas of emphasis. State assessments in reading were statistically higher for middle school students using laptops in Maine (Silvernail, 2008) and high school students in Henrico County, Virginia (Mann, 2008). Students in 1:1 laptop programs at the middle school level (grades six through eight) outperformed their peers on English language arts tests in Massachusetts (Bebell \& Kay, 2010) and California (Gulek \& Demirtas, 2005) while third and fourth grade students performed higher in communication arts in Missouri (Huntley \& Greever-Rice, 2007). The only pilot program reporting mixed results across grade levels was the Texas Immersion Pilot, where participation in the laptop program did not produce significant improvement for seventh and eighth grade students but did for the ninth grade participants.

Math. Research on the impact that 1:1 computing has on math achievement is less extensive than for writing and has mixed findings. Large scale initiatives that took place in Missouri and South Carolina with intermediate and middle school students showed statistically higher scores on the state math assessments for 1:1 laptop students in comparison to students not participating in the 1:1 pilot (Holcomb, 2009; Huntley \& 
Greever-Rice, 2007). Similar projects in Texas, Massachusetts, and Maine produced mixed results. Two of the three grade levels (seventh and eighth grades) participating in the Texas Immersion Pilot achieved significantly higher scores on the math section of the Texas Assessment of Knowledge and Skills (TAKS) while ninth grade scores were higher, but not significantly so, for students in the 1:1 laptop pilot program. Bebell and Kay (2010) found laptop student scores to be significantly higher on the Massachusetts Comprehensive Assessment System (MCAS) math test in the first year of implementation, but not the following two years. They noted that there was an "unprecedented two year improvement in eighth grade math pass rates across pilot schools that correspond with the years students participated in the 1:1 laptop program" ( $\mathrm{p}$. 33). Upon initial study of the Maine Learning Initiative's effect on math scores, Silvernail (2008) reported no statistical improvement in scores over the first three years of the program. However, following content- specific professional development for math teachers, Silvernail and Buffington (2009) filed a policy brief with the state indicating a statistically significant improvement in the MEA math scores for students taking math from teachers participating in this training. One explanation for the mixed results on state mathematics assessments may be linked to laptops being used less frequently in this content area (Bebell \& Kay, 2010; Holcomb, 2009).

In their study of one middle school in California, Gulek and Demirtas (2005) reported significantly higher scores in math for laptop students on both the state math assessment and the nationally norm-referenced California Achievement Test. Lowther et al. (2003) discovered that students participating in a 1:1 laptop program scored 
significantly higher than students in a 5:1 technology model on a locally developed problem solving assessment.

A large scale project in Henrico County, Virginia, reported a negative relationship between laptop use and Algebra I and II scores over a three year period. The relationship was significant for the first two years and dissipated by the third year (Mann, 2008). Geometry scores decreased in the first two years of implementation (no statistical significance) and then significantly increased in the third year when laptops were used at least once a week.

Science and social studies. There are very few studies that examine the impact of 1:1 computing on student achievement in science and social studies. Early evaluation of the 1:1 program in Missouri (grades three through six) found that students in the 1:1 classrooms significantly outperformed students in non-laptop classrooms in both science and social studies during the first year of implementation. As the program expanded over the next eight years, results continued to demonstrate that students in the 1:1 laptop program outperformed their peers in both content areas (Meyers \& Brandt, 2010). A study of urban middle school students participating in a 1:1 laptop program for two years revealed a significant difference in performance on the state achievement test in science between students using laptops and those not using laptops (Dunleavy \& Heinecke, 2007).

Demographic groups. When researchers analyzed the impact of 1:1 computing on student achievement by subgroup, the benefits held true across multiple groups. Huntley and Greever-Rice (2007) conducted an extensive analysis of their findings for the Missouri program and found pilot participants significantly outperformed non- 
participants in math and communication arts in all subgroups with the exception of students with disabilities and Black students. Females were found to be the greatest beneficiaries of 1:1 computing in communication arts, while non-Black minority students achieved the greatest gains in math. Economically disadvantaged students also benefited from participation in the 1:1 program across both communication arts and math. Followup studies of this same program revealed the largest effect sizes for disadvantaged students across all four content areas that were assessed (Meyers \& Brandt, 2010).

\section{Contrary Research}

Cuban (2001) is frequently cited by researchers who conclude that computers have no impact on student achievement. After studying two high schools from the Silicon Valley in 1999 that had high access to computers in the school, but not inside each classroom, he found that computers were not frequently used by students, and teachers largely maintained pre-existing, traditional instructional practices. Although there was great opportunity for change at these two schools located in one of the most technologically innovative locations in the nation, little change occurred in the learning process, and there was no impact on student achievement. Computer ratios for the two high schools in the study were 4:1 and 5:1.

One of the most extensive 1:1 programs in the United States took place in Henrico County, Virginia, where approximately 23,000 middle and high school students were issued laptops in 2001. As indicated earlier, there were mixed results regarding student test scores throughout this massive program. Student achievement was positively impacted in reading, science, and history but was negatively impacted in Algebra I and II, Geometry, and writing after the first year. When surveyed at the end of the third year of 
implementation, teachers felt that the laptops had not made a difference in student grades, quality of work, written expression, and closing the achievement gap (Mann, 2008). Teachers in Henrico County felt that the program did not improve student attendance and were concerned that the laptops were distracting to students.

The Texas Immersion Pilot involved 21 middle schools with approximately 7,000 students in grades seven through nine. After four years of implementation, Ganner (2008) reported that there had been no statistically significant improvement in scores on the Texas Assessment of Knowledge and Skills (TAKS) in reading, writing, or math. When data were analyzed based on the level of implementation at each of the schools, there were significant differences in student test scores between high implementation and low implementation schools (Shapley et al., 2010). In their study on the implementation fidelity of the pilot program, they found that only $29 \%$ of the schools met criteria for full implementation after four years.

Several schools have discontinued their ubiquitous computing program in the past two years. Some of these schools include Romoland Schools in California, Matoaca High School and T. C. Williams High School in Virginia, Liverpool High School in New York, and Rea Elementary School in California (Bahrampour, 2006; Hu, 2007; Lei, 2010a). The most commonly cited reasons for discontinuing the program were the lack of student use, frequent need for repairs, and distraction in the classroom.

When $1: 1$ computing programs have failed to make a statistically significant difference in test scores, researchers have suggested the following reasons for their findings. Several of the studies occurred following one to three years of implementation and lacked the time necessary for a major reform to produce significant results (Holcomb 
2009; Silvernail \& Gritter, 2007). Studies that examine only one year of data need to account for the possibility that scores may decrease for a short time (implementation dip) while participants learn how to use the technology (Rockman, 1998). The most common explanation for the difference in results is the wide variation in the depth of implementation (especially when implementation details of large scale pilots are left up to individual schools) that occurred across programs (Holcomb, 2009; Silvernail \& Gritter, 2007; Shapley et al., 2010).

Previous research overwhelmingly supports the positive impact that 1:1 computing has on all three components of student engagement: behavioral, cognitive, and motivational. Student engagement has been positively linked to student achievement and, therefore, 1:1 computing is a program that can positively affect student achievement. Although results are mixed when analyzing individual 1:1 programs, when examined collectively, 1:1 computing has had a positive impact on student achievement in writing, English language arts, math, and science when there is deep implementation of the program. 


\section{Chapter 3}

\section{Methodology}

This chapter explains the methodology that was used to investigate the effect that 1:1 computing has on student achievement. It begins with a discussion of the research purpose and design followed by a description of the data collection strategies. The chapter concludes with a description of how the data were analyzed.

\section{Research Purpose}

The purpose of the study is to evaluate the impact that $1: 1$ computing programs have on student achievement in Ohio high schools. It is a quantitative study, using an Interrupted Time Series (ITS) design combined with an Individual Participant Data (IPD) meta-analysis and factorial analysis of variance (ANOVA), to determine if student achievement on the Ohio Graduation Test is significantly different following the implementation of a 1:1 computing program.

\section{Research Questions}

The emphasis of this dissertation is to examine the effect of $1: 1$ computing on student achievement. The study is based on the following research questions.

1. Does implementation of a 1:1 computing environment in Ohio high schools affect student achievement?

2. Does the effect of 1:1 computing, as measured by test scores on the Ohio Graduation Test (OGT), vary by content area including math, reading, science, social studies, and writing?

3. Does the longevity of the 1:1 program influence the effect it has on student achievement? 
4. Does the effect of 1:1 computing vary by demographic group?
a. Gender;
b. Race;
c. Disability status; and
d. Economic status.

5. Does the type of device used by the students (laptop, netbook, or tablet) influence the effect 1:1 computing has on student achievement?

\section{Research Design}

An Interrupted Time Series (ITS) design was used to compare the trend for student performance on the OGT for several years prior to the deployment of a 1:1 program with the trend for student performance on the OGT for several years following deployment. The core component of a time series design is the presence of a periodic measurement process for a group with the introduction of some type of intervention or interruption in the series of measurements. In the current study, the intervention/interruption is the implementation of a 1:1 computing program. The data were examined for any discontinuities as a means to evaluate the impact of the intervention (Campbell \& Stanley, 1963).

An ITS design is a segmented regression where the slope of the line for results on the OGT for several years prior to program implementation serves as the pretest measure, and the slope of the line for results following implementation of the 1:1 program serves as the posttest measure. By examining multiple data points in a time series, compared to the inspection of one data point prior to implementation and one following implementation, the time series design controls for several threats to internal validity 
including testing, regression, selection, mortality and interaction threats (Campbell \& Stanley, 1963).

A multiple time series design was used for the current investigation as a more rigorous method for examining the effect of 1:1 computing by matching each high school in the treatment group to a similar high school without a 1:1 program. The use of a control group provides comparative data which strengthen the research design by limiting the number of alternative hypotheses (Gottman, McFall, \& Barnett, 1969). This type of ITS design, with data from multiple treatment schools and similar control schools, makes use of more extensive data over time and is a great improvement over the analysis of only one data point before and one after the implementation of a new program (Campbell \& Ross, 1968).

\section{Participants}

A purposive sampling method was utilized to compile a list of all the Ohio high schools that have implemented a 1:1 computing environment with all sophomores for at least one year. High schools that have 1:1 programs were identified by contacting members of the state technology department (eTECH) and receiving input from technology associates, including vendor sales' representatives and supervisory personnel at educational service centers throughout the state. A request to identify any high schools implementing a 1:1 program was sent to all Ohio districts using the state-wide email distribution list for superintendents, high school principals, and district technology supervisors. After generating a list of potential high schools to participate in the study, each school was contacted to determine when the program was implemented, what devices are being used, and whether students are permitted to take the devices home. 
Any schools that did not meet the timeline for implementation (between July, 2008 and September, 2012) or that do not allow students to take the devices home were excluded from the study.

To serve as a control, each public high school in the study was paired with a non1:1 high school from the district that is ranked as being most similar using the Ohio similar district methodology for fiscal year 2013 on the ODE web page. Several factors such as the average daily membership, median income, population density, student demographic percentages for minority enrollment and poverty, and adult demographic percentages for college degrees and professional occupations are incorporated into the methodology.

Parochial high schools with 1:1 programs were manually paired with a non-1:1 parochial high school based on (a) gender configuration - coeducational, all-male or allfemale student bodies, (b) enrollment, and (c) racial composition.

There are 24 high schools with 1:1 computing programs that met the conditions required for inclusion in the study. Public high schools are located in districts that have only one school at this level within the district. Table 1 provides a list of the 24 pairs of schools that participated in the study. 
Table 1

Participating High Schools by Pair

\begin{tabular}{|c|c|c|c|}
\hline Treatment HS & District & Control HS & District \\
\hline Anderson & Lisbon EVSD & Oak Hill & Oak Hill Union Local \\
\hline Archbold & Archbold Area Local & Tinora & Northeastern Local \\
\hline Ayersville & Ayersville Local & Hopewell-Loudon & Hopewell-Loud. Local \\
\hline Canton South & Canton Local & Bath & Bath Local \\
\hline Columbiana & Columbiana EVSD & Wheelersburg & Wheelersburg Local \\
\hline Defiance & Defiance City & Norwalk & Norwalk City \\
\hline Fairlawn & Fairlawn Local & Hardin Northern & Hardin Northern Local \\
\hline Fort Recovery & Fort Recovery Local & Triad & Triad Local \\
\hline Hicksville & Hicksville EVSD & East Canton & Osnaburg Local \\
\hline Indian Valley & Indian Valley Local & Minerva & Minerva Local \\
\hline John F. Kennedy & Youngstown Diocese & Central Catholic & Cincinnati Diocese \\
\hline Kalida & Kalida Local & Ottoville & Ottoville Local \\
\hline Licking Valley & Licking Valley Local & Jefferson & Jefferson Area Local \\
\hline Loudonville Perrysville & Loudon. Perry. EVSD & Barnesville & Barnesville EVSD \\
\hline New Lexington & New Lexington City & Fairless & Fairless Local \\
\hline Pandora-Gilboa & Pandora-Gilboa Local & Pettisville & Pettisville Local \\
\hline Perkins & Perkins Local & Monroe & Monroe Local \\
\hline Shelby & Shelby City & Memorial & St. Mary’s City \\
\hline St. John's & Youngstown Diocese & St. Joseph Central & Steubenville Diocese \\
\hline St. John's Jesuit* & Toledo Diocese & St. Francis DeSales* & Toledo Diocese \\
\hline St. Ursula** & Toledo Diocese & Beaumont** & Cleveland Diocese \\
\hline Utica & North Fork Local & Clear Fork & Clear Fork Valley \\
\hline Van Buren & Van Buren Local & Perry & Perry Local \\
\hline Vermilion & Vermilion Local & Lakewood & Lakewood Local \\
\hline
\end{tabular}

Note. * All-Male School, ** All-Female School

Additional information on the study participants is presented in Appendix A. 


\section{Data Collection}

OGT and school demographic information was obtained from the ODE using their web page to access Building Report Card data for public schools (ODE, 1998). The data that were taken from report cards include the school rating, performance index, percentage of students with a disability or economic disadvantage, and the percentage of economically disadvantaged students scoring proficient or above in each content area. Similar information for the parochial schools was manually calculated including the performance index, a rating was assigned based on the PI score, and schools were contacted to request information about economically disadvantaged students.

DVDs made available to state repository libraries were used to access archived data for both public and parochial schools for each administration of the OGT. Data retrieved from this source include mean scaled scores and the number of students tested for each content area. Information is reported for the total group, broken down by gender - male and female, disaggregated by race - American Indian, Asian/Pacific Islander, Black, Hispanic, White, Multi-Racial and Other, and reported for students on an Individualized Education Plan (IEP). The percentage of White students reported for each school was calculated using the raw data from the number of White and total number of students tested.

Scores for sophomores taking the March administration of the OGT between March 2005 and March 2013 were utilized to assess student performance. Overall performance was measured with performance index (PI) scores and mean scaled scores were used to assess content area performance. Scaled scores, disaggregated by gender, race, and disability status were examined to ascertain student performance by 
demographic subgroup. The lone measure available to study the performance of economically disadvantaged (ED) students was the percentage of students scoring proficient or above, which is only provided for the public schools on the ODE web page.

\section{Instrumentation}

The testing instrument used in the study to measure student achievement is the Ohio Graduation Test (OGT), which is a criterion-referenced test in five content areas, including mathematics, reading, science, social studies, and writing. Each test is aligned to the academic standards for that content area as adopted by the state board of education in 2002 (ODE, 2011). The mathematics and reading sections of the OGT were initially administered to sophomores in March 2004 and the other three sections were added in March 2005. All five sections are administered to sophomores throughout Ohio during the second week of March each year and will continue through March 2014. Over the nine year span, when all five sections of the test have been administered to sophomores, sample sizes range from a high of 151,387 students in 2007 to a low of 139,459 students in 2013 (ODE, 2004b). Student raw scores are converted and reported as scaled scores that fall into one of five performance levels. The performance levels include the following descriptors and approximate scores - limited (up to 382), basic (383-399), proficient (400-424), accelerated (425-448), and advanced (above 448). Students must attain at least a proficient score on each section of the test as one of their requirements for graduation.

Each test consists of multiple choice and open response items and is constructed using a specific blueprint that is consistent for all administrations of the test (ODE, 2004a). 
Table 2 provides a summary of the testing blueprints for the OGT.

Table 2

OGT Test Blueprints from 2005 through 2013

\begin{tabular}{llllll}
\hline Content Area & $\begin{array}{l}\text { Multiple } \\
\text { Choice }\end{array}$ & $\begin{array}{l}\text { Short } \\
\text { Answer }\end{array}$ & $\begin{array}{l}\text { Extended } \\
\text { Response }\end{array}$ & Items & $\begin{array}{l}\text { Total } \\
\text { Points }\end{array}$ \\
\hline Mathematics & 32 & 5 & 1 & 38 & 46 \\
Reading & 32 & 4 & 2 & 38 & 48 \\
Social Studies & 32 & 4 & 2 & 38 & 48 \\
Science & 32 & 4 & 2 & 38 & 48 \\
Writing & 10 & 1 & 2 & 13 & 48 \\
\hline
\end{tabular}

Ohio uses the Rasch modeling for computing item difficulties and equates test forms for each administration. Raw scores are converted to scaled scores to provide consistency across different forms of the test. A concordance between raw scores and scaled scores for all five sections of the test are provided following each administration of the OGT (ODE, 2004c).

Table 3 provides a summary of the descriptive statistics for the March administration of the OGT for the time series used throughout this dissertation.

Table 3

Range of Descriptive Statistics for OGT Scaled Scores from 2005 through 2013

\begin{tabular}{lcccc}
\hline Content Area & $M$ & $S D$ & SEM & Cornbach's $\alpha$ \\
\hline Mathematics & $426.4-436.6$ & $29.9-35.5$ & $6.8-10.3$ & $.91-.95$ \\
Reading & $421.8-434.2$ & $22.1-25.9$ & $6.3-8.9$ & $.86-.92$ \\
Writing & $423.5-431.0$ & $21.2-31.3$ & $6.1-11.8$ & $.79-.93$ \\
Science & $415.9-423.6$ & $28.3-32.5$ & $8.5-11.3$ & $.87-.93$ \\
Social Studies & $422.7-432.2$ & $29.3-35.5$ & $7.7-10.8$ & $.89-.91$ \\
\hline
\end{tabular}




\section{Data Analysis}

Data were collected and analyzed at the school level over a period of five to eight years depending on when the treatment (1:1) program was implemented. A variety of methods were used to analyze the data depending on the research question, the availability of data, and the sample size.

Primary or individual participant data (IPD) meta-analysis was used to explore research questions that require the analysis of the full sample and use performance index (PI) or mean scaled scores as a measure of student performance. Meta-analysis methods involve combining and analyzing data from related studies to produce results based on a whole body of research. Traditional methods of meta-analysis synthesize aggregate level data obtained from published studies, whereas IPD meta-analysis uses individual level data to synthesize the results (Riley, Lambert, \& Abo-Zaid, 2010). Schools are the unit of analysis for this study. Rather than conducting a meta-analysis of several published studies, the current investigation synthesizes the results of each school over time as if it were its own study. In other words, data for each school (individual) will be analyzed over time and in comparison to its' similar high school instead of comparing the mean pre- and post-implementation scores for the treatment and control groups collectively. IPD meta-analysis can produce more relevant results than aggregate data, going beyond the "grand mean" and producing a more reliable examination of the effect for a given intervention. Use of an IPD meta-analysis improves the quality of the analysis because it allows for time to event analysis, provides better exploration of effects at the individual school level, and has increased power to detect interactions (Stewart, Rydzewska, \& Vale, 2010). 
There are four distinct points in time when a 1:1 treatment program was implemented (and the time series was interrupted) during this investigation. A multivariate linear regression model was used to examine the relationship between the longevity of the treatment program and student achievement. Curve fitting is the simplest and best known approach to the analysis of time series data (Gottman, McFall, \& Barnett, 1969). Data are divided into two classes, one with data preceding the intervention and one including data following the intervention. One straight line is fitted to the first class of data and another is fitted to the second class of data. The slope and intercept of both lines is projected to the point of intervention and an appropriate significance test is performed. In addition to performing an $\mathrm{F}$ test for significance, achievement data are presented graphically using an ITS format to visually compare OGT scores before and during implementation of a 1:1 computing program for both the treatment and control groups.

Evaluation of the data by subgroup required the use of a factorial analysis of variance (ANOVA) due to limited availability of data. Several schools did not have a sufficient number of students to report scores by race other than for the White subgroup, for the IEP students, or for the ED students. When data were available for the various subgroups, it was inconsistently reported across all five to eight years of the study for some schools. Factorial designs focus on the treatment, its components, and its major dimensions and enables the researcher to determine whether the treatment has an effect, whether subcomponents are effective, and whether there are interactions in the effects caused by the subcomponents. This design is especially efficient because it enables the researcher to examine which features (group membership and period in this study) have 
an effect individually or in combination with one another (interaction between group and period) (Trochim \& Donnelly, 2008).

\section{Delimitations}

The current study focuses on high schools because there are few studies on 1:1 computing at this level and none that examine the impact on student achievement across certain content areas.

The sample is limited to schools that have implemented a 1:1 program between one and four years. The iPad is the most popular tablet used in the educational arena and it was not introduced into the market until January of 2011. In order to collect data on the impact of this device, schools with test scores for a minimum of one year following implementation of the program were included in the study. The five year limit was imposed in an attempt to limit the differences in the technological aspects of the program (equipment improves at a rapid rate) that could impact the results. 


\section{Chapter 4}

\section{Results}

The purpose of this study is to examine the impact that $1: 1$ computing has on student achievement as measured by OGT test scores. All the OGT data were obtained from the Ohio Department of Education via their website or through results published electronically on DVDs for each administration of the test available at state repository libraries. Data were hand entered into Microsoft Excel spreadsheets and then imported and analyzed using SPSS (version 18) and Comprehensive Meta-Analysis software. Data were collected and analyzed at the aggregate level with the school building serving as the unit of analysis. There are a total of 48 schools included in the study with an average of 5,362 students participating in each administration of the OGT. Student achievement measures were analyzed to determine if there were any statistically significant differences in the change in student test scores from the pre-treatment period (prior to implementation of the $1: 1$ program) to the treatment period (1:1 program in place) when comparing the treatment and control groups.

\section{Descriptive Analysis}

Performance index (PI) is being examined as a measure of overall student achievement. Scores were compiled for 24 control schools and 24 treatment schools over a period of five to eight years with $n=140$ for the control group and $n=140$ for the treatment group. The descriptive statistics for performance index scores are presented in Table 4. 
Table 4

Descriptive Statistics for Performance Index

\begin{tabular}{lcrrr}
\hline Group & $M$ & $S D$ & Skewness & Kurtosis \\
\hline Control & 102.54 & 5.12 & -0.020 & -0.379 \\
Treatment & 102.62 & 4.86 & -0.167 & -0.189 \\
\hline
\end{tabular}

As seen in Table 4, the mean performance index scores for the two groups are essentially the same with a difference of .08 .

The two groups were broken into time clusters based on the number of years that a 1:1 program was implemented in each treatment school. Each control school was placed in the same time cluster as the reciprocal treatment school. An analysis of performance index scores by implementation time cluster is presented in Table 5.

Table 5

Descriptive Statistics for Performance Index by Implementation Time Cluster

\begin{tabular}{clrrrrr}
\hline Time & Group & $\mathrm{n}$ & $M$ & $S D$ & Skewness & Kurtosis \\
\hline \multirow{2}{*}{1} & Control & 60 & 101.90 & 4.55 & -0.185 & -0.036 \\
& Treatment & 60 & 102.75 & 4.94 & 0.050 & -0.259 \\
2 & Control & 42 & 102.97 & 6.48 & -0.172 & -0.964 \\
& Treatment & 42 & 101.71 & 5.50 & -0.239 & -0.402 \\
3 & Control & 14 & 99.98 & 2.34 & 0.741 & 0.603 \\
& Treatment & 14 & 102.04 & 3.63 & 0.230 & -1.736 \\
\multirow{2}{*}{4} & Control & 24 & 104.87 & 4.06 & 0.210 & -1.383 \\
& Treatment & 24 & 104.25 & 3.73 & -0.003 & -0.995 \\
\hline
\end{tabular}

As displayed in Table 5, the aggregate PI score for the treatment group is higher in time clusters one (.85) and three (2.06) while the aggregate PI score is higher for the control 
group in clusters two (1.26) and four (.62). A similar analysis of PI scores by pair can be found in Appendix B.

Mean scaled scores (SS) are being investigated as a measure of student achievement in each content area. Scores were compiled for mathematics, reading, science, social studies, and writing for 24 control schools and 24 treatment schools over a period of five to eight years with $n=140$ for the control group and $n=140$ for the treatment group. The descriptive statistics for total scaled scores are presented in Table 6.

Table 6

Descriptive Statistics for Total Scaled Scores

\begin{tabular}{llclll}
\hline Content Area & Group & $M$ & $S D$ & Skewness & Kurtosis \\
\hline Math & Control & 439.14 & 8.90 & 0.386 & 0.226 \\
& Treatment & 438.27 & 8.64 & -0.105 & -0.534 \\
Reading & Control & 430.52 & 7.13 & 0.567 & -0.030 \\
& Treatment & 429.86 & 6.20 & 0.040 & 0.205 \\
Science & Control & 427.57 & 8.22 & 0.490 & 0.170 \\
& Treatment & 426.76 & 6.74 & -0.238 & -0.278 \\
Social Studies & Control & 434.50 & 8.83 & 0.159 & 0.150 \\
& Treatment & 434.52 & 8.38 & 0.012 & -0.287 \\
Writing & Control & 430.08 & 9.24 & 0.753 & -0.097 \\
& Treatment & 430.12 & 8.09 & 0.287 & -0.181 \\
\hline
\end{tabular}

The mean scaled score for the control group is slightly greater than the treatment group in math, reading, and science with differences of $.87, .66$, and .81 , respectively. Both groups have essentially the same mean scaled scores in social studies and writing. 
Descriptive statistics for each content area broken down by time cluster and pair are reported in Appendix C.

Mean scaled scores were also disaggregated to examine student performance by subgroup. A subgroup must include at least 10 individuals to be included in the disaggregated results for any school. A maximum value of $n=700$ indicates that the subgroup is large enough to be reported for every administration of the OGT, for each high school, for every year that the school was part of the study. Scaled scores are not reported by ODE for the economically disadvantaged subgroup. Table 7 displays mean scaled scores for the entire sample (all five content areas) broken down by gender, race, and disability status. 
Table 7

Descriptive Statistics for Mean Scaled Scores by Demographic Subgroup

\begin{tabular}{|c|c|c|c|c|c|c|c|}
\hline Variable & & Group & $n$ & $M$ & $S D$ & Skewness & Kurtosis \\
\hline \multicolumn{8}{|l|}{ Gender } \\
\hline & Female & Control & 645 & 431.78 & 9.24 & 0.277 & -0.071 \\
\hline & & Treatment & 650 & 431.91 & 9.01 & 0.245 & 0.033 \\
\hline & Male & Control & 635 & 431.02 & 10.16 & 0.407 & -0.022 \\
\hline & & Treatment & 640 & 431.18 & 9.83 & 0.250 & -0.180 \\
\hline \multicolumn{8}{|l|}{ Race } \\
\hline & White & Control & 700 & 433.07 & 9.77 & 0.480 & -0.043 \\
\hline & & Treatment & 700 & 432.88 & 8.98 & 0.220 & -0.263 \\
\hline & Black & Control & 74 & 425.73 & 12.95 & -0.443 & 0.094 \\
\hline & & Treatment & 119 & 418.74 & 12.04 & -0.005 & -0.563 \\
\hline & Hispanic & Control & 25 & 414.53 & 10.15 & -0.036 & 0.072 \\
\hline & & Treatment & 60 & 420.09 & 8.54 & 0.317 & 0.707 \\
\hline & Other & Control & 157 & 422.82 & 9.48 & 0.205 & 0.519 \\
\hline & & Treatment & 156 & 428.71 & 10.51 & -0.322 & 0.235 \\
\hline \multicolumn{8}{|l|}{ Disability } \\
\hline & IEP & Control & 342 & 397.94 & 7.90 & 0.048 & -0.213 \\
\hline & & Treatment & 383 & 399.70 & 9.97 & 0.108 & 1.151 \\
\hline
\end{tabular}

As seen in Table 7, the treatment group is slightly larger than the control group, and, in both groups, there are more females than males. Disaggregate data are not provided for six schools due to low enrollment $(n=2)$ and/or single gender populations $(n=4)$. The mean scaled scores across both genders and both groups are equivalent for all practical purposes with differences of less than one point across the four values.

Race is reported in one of seven subgroups including American Indian, Asian/Pacific Islander, Black, Hispanic, White, Multi-racial, or Other. The study sample 
includes a limited number of subgroups as recorded in Table 7. There is sufficient enrollment to report the White subgroup for every administration of the test, $n=700$, with similar means for both the control and the treatment groups (difference of .19). The treatment group is more diverse than the control group with larger sample sizes for both the Black and Hispanic subgroups. The mean scaled scores across the last three racial subgroups reveal differences with the control group performing higher than the treatment group for Blacks, while the treatment group outperforms the control group for the Hispanic and Other subgroups.

Students with disabilities are reported as students with Individual Education Plans (IEP) in Table 7. The treatment group is larger and has a somewhat higher mean than the control group for this demographic category. Descriptive statistics for each content area, disaggregated by demographic subgroup, are reported in Appendix C.

Student achievement for the economically disadvantaged subgroup is being measured with the percentage of students scoring at the proficient achievement level or higher. A student is categorized as economically disadvantaged if the student qualifies for free or reduced lunch prices in the National School Lunch Program. Data for economically disadvantaged students attending parochial schools are not available from ODE. Therefore, the information presented in Table 8 is limited to the public schools participating in the study. 
Table 8

Percentage of Students Scoring Proficient or Above Broken Down by Economic Status

\begin{tabular}{|c|c|c|c|c|c|c|c|}
\hline Content & Group & Economic Status & $n$ & $M$ & $S D$ & Skew & Kurtosis \\
\hline \multirow[t]{4}{*}{ Math } & Control & Not Disadvantaged & 115 & 0.925 & 0.045 & -.486 & -.434 \\
\hline & & Disadvantaged & 107 & 0.793 & 0.102 & -.455 & .618 \\
\hline & Treatment & Not Disadvantaged & 115 & 0.923 & 0.053 & -.688 & .423 \\
\hline & & Disadvantaged & 95 & 0.818 & 0.094 & -.103 & -.529 \\
\hline \multirow[t]{4}{*}{ Reading } & Control & Not Disadvantaged & 115 & 0.932 & 0.040 & -.379 & -.104 \\
\hline & & Disadvantaged & 107 & 0.832 & 0.090 & -.390 & -.508 \\
\hline & Treatment & Not Disadvantaged & 115 & 0.931 & 0.048 & -1.281 & 1.857 \\
\hline & & Disadvantaged & 95 & 0.829 & 0.085 & -.461 & .042 \\
\hline \multirow[t]{4}{*}{ Science } & Control & Not Disadvantaged & 115 & 0.876 & 0.062 & -.313 & .101 \\
\hline & & Disadvantaged & 107 & 0.731 & 0.116 & .066 & -.112 \\
\hline & Treatment & Not Disadvantaged & 115 & 0.885 & 0.061 & -.462 & -.279 \\
\hline & & Disadvantaged & 95 & 0.742 & 0.111 & -.270 & -.035 \\
\hline \multirow[t]{4}{*}{$\begin{array}{l}\text { Social } \\
\text { Studies }\end{array}$} & Control & Not Disadvantaged & 115 & 0.899 & 0.053 & -.684 & 1.531 \\
\hline & & Disadvantaged & 107 & 0.770 & 0.104 & .184 & -.189 \\
\hline & Treatment & Not Disadvantaged & 115 & 0.908 & 0.052 & -.752 & .645 \\
\hline & & Disadvantaged & 95 & 0.765 & 0.097 & -.100 & -.875 \\
\hline \multirow[t]{4}{*}{ Writing } & Control & Not Disadvantaged & 115 & 0.943 & 0.042 & -.850 & .734 \\
\hline & & Disadvantaged & 107 & 0.847 & 0.091 & -.228 & -.350 \\
\hline & Treatment & Not Disadvantaged & 115 & 0.944 & 0.043 & -1.022 & .882 \\
\hline & & Disadvantaged & 95 & 0.856 & 0.085 & -.287 & -.809 \\
\hline
\end{tabular}

Table 8 reveals students who are economically disadvantaged score lower than their nondisadvantaged counterparts across all five content areas within the control and treatment groups. When examining the disadvantaged students, the treatment group has a larger percentage of students scoring proficient in math, science, and writing. The two groups 
have similar scores (within half of a percentage point) in reading and social studies.

Among the non-disadvantaged students, performance across all five content areas is comparable for both the control and treatment groups with differences across the groups of less than one percentage point in each area.

Information describing the 1:1 programs implemented in the treatment schools $(n$ $=24)$ is presented in Table 9 .

Table 9

Frequency Data for Treatment Schools

\begin{tabular}{lcl}
\hline Variable & Frequency & Percentage \\
\hline Longevity of 1:1 Program & & \\
1 year & 12 & 50.0 \\
2 years & 7 & 29.1 \\
3 years & 2 & 8.3 \\
4 years & 3 & 12.5 \\
Type of School & & \\
Public & 20 & 83.3 \\
Parochial & 4 & 16.7 \\
Device & & \\
Laptop & 9 & 37.5 \\
Netbook & 7 & 29.2 \\
iPad & 8 & 33.3 \\
\hline
\end{tabular}

The longevity of the 1:1 program indicates the number of years that the program has been implemented at each school and is also referred to as an implementation time cluster. As indicated in Table 9, half of the study schools have had a 1:1 program for one year, seven schools have been implementing a program for two years, only two schools are included in the three year time cluster, and three schools have had a 1:1 program for four years. 
Each of the 20 public schools is paired with another public school as a comparison school, while the four parochial schools are paired with similar parochial schools as a control group. The type of devices being used in the 1:1 programs are fairly evenly distributed with $29 \%$ of the treatment schools using netbooks, $33 \%$ using iPads (the only tablet being used by all treatment schools), and 38\% using laptops. Similar information about the treatment schools, broken down by time cluster, can be found in Appendix D.

\section{Preliminary Analysis}

Zero-order correlations were calculated across all the groups with scaled scores as the dependent variable to determine the strength of relationship between variables. Results are displayed in Table 10.

Table 10

Zero-Order Correlation of Mean Scaled Scores

\begin{tabular}{|c|c|c|c|c|c|c|c|c|}
\hline & Total & Female & Male & White & Black & Hispanic & Other & IEP \\
\hline Total & 1 & $0.895^{* *}$ & $0.923^{* *}$ & $0.988^{* *}$ & $0.765^{* *}$ & $0.567 * *$ & $0.725^{* *}$ & $0.523^{* *}$ \\
\hline Female & & 1 & $0.643^{* *}$ & $0.879^{* *}$ & $0.805^{* *}$ & $0.629 * *$ & $0.691^{* *}$ & $0.528^{* *}$ \\
\hline Male & & & 1 & $0.922 * *$ & $0.532 * *$ & $0.313^{* *}$ & $0.571^{* *}$ & $0.410^{* *}$ \\
\hline White & & & & 1 & $0.681 * *$ & $0.468^{* *}$ & $0.673^{* *}$ & $0.501^{* *}$ \\
\hline Black & & & & & 1 & 0.105 & $0.614^{* *}$ & $0.609^{* *}$ \\
\hline Hispanic & & & & & & 1 & $0.677^{* *}$ & $0.460^{* *}$ \\
\hline Other & & & & & & & 1 & $0.283^{* *}$ \\
\hline IEP & & & & & & & & 1 \\
\hline
\end{tabular}


As seen in Table 10, positive significant correlations exist between all of the groups with the exception of the Black and Hispanic subgroups. A large correlation (.8) exists between the total group and the female, male and White subgroups, the White subgroup and females and males, and between females and Blacks. All other significant correlations fall within the moderate range (Field, 2009).

\section{Assumptions}

Dependent variables (criterions) are all continuous in measurement, and independent variables (predictive) are all categorical in measurement. The dependent variables, scores on various measures including PI and scaled scores, are normally distributed. The data for each of the 48 schools are assumed to be independent. All error degrees of freedom that are at least $d f=20$ support the tenability of the multivariate analyses assumptions, where significant results are revealed (Tabachnick \& Fidell, 2013). All analyses are evaluated for statistical as well as practical significance.

\section{Data Analysis}

Student performance, the dependent variable in this study, was measured by performance index scores and scaled scores. Data for these two measures were analyzed at two levels including the full sample (composite) and then broken down by time cluster. The two groups are consistently identified as the treatment group (schools with a 1:1 program) and the control group (no 1:1 program). Student achievement is compared over time by examining test scores during a pre-treatment period (prior to implementation of a 1:1 program) to test results that occurred during the treatment period (1:1 programs implemented and remained in place for one to four years). Control schools did not have a 1:1 program at any time throughout the study but test results were placed into a pre- 
treatment or treatment period to coincide with the same timeframe as the 1:1 school it was paired with. Results of each analysis are organized by research question in this section.

\section{Overall achievement using performance index scores.}

PI scores were analyzed to address the following research questions.

1. Does implementation of a 1:1 computing environment in Ohio high schools affect student achievement?

3. Does the longevity of the $1: 1$ program influence the effect it has on student achievement?

IPD meta-analysis is consistently used throughout the study when examining both levels of the sample. Results provided for meta-analytic procedures focus on a $\mathrm{Q}$ statistic. Q is a measure of group differences and tests the assumption of whether the groups are homogeneous. A significant $p$ value indicates that groups are not homogeneous, and therefore are considered statistically different (Borenstein, Hedges, Higgins, \& Rothstein, 2009).

PI scores for the pre-treatment and treatment periods were examined for the composite sample using meta-analysis. Results indicate that there are no significant differences within or between the control and treatment groups, $Q(1)=.244, p=.621$.

A multivariate linear regression model was used to analyze the sample broken down by time cluster. Since there are four distinct school years when the treatment was initially implemented, from August 2009 to August 2012, the sample was divided into four time clusters based on when the 1:1 program was started. Shadish, Cook, and Campbell (2002) provided guidelines for performing the aggregate panel interrupted time 
series analysis used in the current investigation. Panels (time clusters) were constructed for data in each "time" cohort ( 1 year, 2 years, 3 years, or 4 years). The analysis included the predictive variable of time (year) regressed on the criterion variable, achievement scores, across the two (treatment and control) groups. In accordance with the Shadish et al. (2002) guidelines, the data for each cluster were centered by year, based on the time of implementation (interruption in the time series). The data analysis began with the examination of the interaction between time and group, followed by group, and then time. When the interaction between time and group was not significant, a second model was analyzed without the interaction.

The regression analysis by time cluster indicates that the pre-treatment and treatment PI scores do not have any significant interactions. A table summarizing the standardized beta $(\beta)$ coefficients for both models, as well as a graphical representation of the PI scores for each time cluster, can be found in Appendix E. In addition to the regression analysis, a meta-analysis of PI scores was examined by time cluster. Time cluster 3 exhibits a significant difference between the control and treatment groups across the pre-treatment and treatment periods, $Q(1)=7.00, p=.008$. Results for all four time clusters can be found in Appendix E.

Further examination of the data reveals that the PI scores improved for the control group while remaining practically the same for the treatment group as seen in Table 11. 
Table 11

PI Means by Treatment Period for Time Cluster 3

\begin{tabular}{|c|c|c|c|c|c|c|c|}
\hline \multirow[b]{2}{*}{ Time } & \multirow[b]{2}{*}{ Group } & \multicolumn{3}{|c|}{ Pre-Treatment Period } & \multicolumn{3}{|c|}{ Treatment Period } \\
\hline & & $n$ & $M$ & $S D$ & $n$ & $M$ & $S D$ \\
\hline \multirow[t]{2}{*}{3} & Control & 8 & 98.85 & 1.631 & 6 & 101.48 & 2.390 \\
\hline & Treatment & 8 & 102.08 & 3.948 & 6 & 102.00 & 3.533 \\
\hline
\end{tabular}

PI scores during the treatment period exhibit a gain of 2.63 points for the control group and a loss of .08 points for the treatment group in this time cluster.

\section{Content area achievement using mean scaled scores.}

The impact of 1:1 computing was scrutinized for each of the five content areas that are assessed on the OGT by analyzing mean scaled scores at the two levels described earlier (composite and time cluster). Results are presented for each of the five content areas to answer the following research questions.

2. Does the effect of 1:1 computing, as measured by test scores on the Ohio Graduation Test (OGT), vary by content area including math, reading, science, social studies, and writing?

3. Does the longevity of the 1:1 program influence the effect it has on student achievement?

\section{Mathematics.}

A meta-analysis was performed on the full sample of 48 schools to determine if significant differences exist between the control and treatment groups before and during implementation of a 1:1 computing program. Results of this analysis indicate that there is not a significant difference in math scores between the two groups, $Q(1)=.544, p=$ 
The multivariate regression analysis by time cluster reveals no significant differences in pre-treatment and treatment mean scaled scores for math. Specific data on the regression analysis is reported in table and graphical formats in Appendix F. Metaanalysis by time cluster shows similar results with none of time clusters demonstrating significant differences between the two groups.

\section{Reading.}

Meta-analysis of the full sample $(n=48)$ reveals no significant differences in reading scores between the control and treatment groups, $Q(1)=.096, p=.757$.

Results for the multivariate regression are displayed in Table 12.

Table 12

Standardized Beta Coefficients ( $\beta$ ) for Regression Models of Reading Scaled Scores by Time Cluster

\begin{tabular}{|c|c|c|c|c|c|}
\hline \multirow[b]{2}{*}{ Time Cluster } & \multicolumn{3}{|c|}{ Model with interaction } & \multicolumn{2}{|c|}{ Model without interaction } \\
\hline & Time & Group & Interaction & Time & Group \\
\hline 1 & 0.105 & 0.071 & 0.076 & 0.148 & 0.026 \\
\hline 2 & 0.126 & -0.192 & -0.057 & 0.089 & -0.170 \\
\hline 3 & $0.520 *$ & 0.042 & 0.043 & $.550 * *$ & 0.035 \\
\hline 4 & -0.045 & -0.055 & -0.045 & -0.077 & -0.055 \\
\hline
\end{tabular}

The first model has no significant interactions as seen in Table 12. However, there is a significant difference across time for time cluster 3 in both models. The positive value for the beta coefficient $(\beta)$ indicates that the reading scores are higher during the treatment period for this time cluster. The lack of an interaction between time and group 
reveals, however, that both groups demonstrate the same positive trend over time. Visual inspection of the graphs presented in Appendix G support this finding.

Meta-analysis of the reading scores by time cluster demonstrates a significant difference between the control and treatment groups for cluster $3, Q(1)=11.94, p=.001$ as seen in Appendix G, Table G2. The overall standardized difference in means, $d=$ 2.621, indicates the treatment group had a larger gain in reading scores than did the control group. Further evidence of this is presented in Table 13.

Table 13

Reading Means by Treatment Period for Time Cluster 3

\begin{tabular}{lllccccc}
\hline & & \multicolumn{3}{c}{$\begin{array}{l}\text { Pre-Treatment } \\
\text { Period }\end{array}$} & & \multicolumn{2}{c}{ Treatment Period } \\
Time & Group & $n$ & $M$ & $S D$ & & $M$ & $S D$ \\
\hline 3 & Control & 2 & 425.35 & 3.91 & & 429.83 & 3.64 \\
& Treatment & 2 & 425.10 & 2.95 & & 430.97 & 2.26 \\
\hline
\end{tabular}

Reading scores for the treatment period display a gain of 5.87 points for the treatment group and 4.48 points for the control group in this time cluster as seen in Table 13.

\section{Science.}

The full sample $(n=48)$ of schools was analyzed using meta-analysis and disclosed no significant differences in science scores between the control and treatment groups, $Q(1)=1.408, p=.235$.

Regression analysis was performed for each time cluster with results presented in Table 14. 
Table 14

Standardized Beta Coefficients ( $\beta$ ) for Regression Models of Science Scaled Scores by Time Cluster

\begin{tabular}{|c|c|c|c|c|c|}
\hline \multirow[b]{2}{*}{ Time Cluster } & \multicolumn{3}{|c|}{ Model with interaction } & \multicolumn{2}{|c|}{ Model without interaction } \\
\hline & Time & Group & Interaction & Time & Group \\
\hline 1 & 0.009 & 0.156 & 0.239 & 0.144 & 0.013 \\
\hline 2 & 0.245 & -0.239 & -0.140 & 0.154 & -0.186 \\
\hline 3 & $0.559 *$ & 0.021 & -0.265 & 0.374 & 0.067 \\
\hline 4 & 0.379 & 0.023 & -0.240 & 0.209 & 0.023 \\
\hline
\end{tabular}

As seen in Table 14, interactions between time and group are not significant in the first model. Scores are significantly different over time for cluster 3 in the first model. A positive $\beta$ indicates that the science scores are higher during the treatment period for this time cluster. Graphical representations of the science scores across time are presented in Appendix H.

A meta-analysis of the science scores by time cluster demonstrates a significant difference between the control and treatment groups for cluster $1, Q(1)=3.94, p=.047$ with results for all four time clusters presented in Appendix H. The overall standardized difference in means, $d=.777$, indicates the treatment group has a larger gain in science scores than the control group. Pre-treatment and treatment means for time cluster 1 are displayed in Table 15. 
Table 15

Science Means by Treatment Period for Time Cluster 1

\begin{tabular}{|c|c|c|c|c|c|c|}
\hline \multirow[b]{2}{*}{ Time } & \multirow[b]{2}{*}{ Group } & \multirow[b]{2}{*}{$n$} & \multicolumn{2}{|c|}{ Pre-Treatment Period } & \multicolumn{2}{|c|}{ Treatment Period } \\
\hline & & & $M$ & $S D$ & $M$ & $S D$ \\
\hline \multirow[t]{2}{*}{1} & Control & 12 & 426.14 & 7.30 & 426.88 & 5.94 \\
\hline & Treatment & 12 & 426.04 & 8.10 & 428.27 & 7.73 \\
\hline
\end{tabular}

Science scores for the treatment period exhibit a gain of 2.23 points for the treatment group and .74 points for the control group in this time cluster.

\section{Social studies.}

Meta-analysis of the full sample $(n=48)$ discloses no significant differences in social studies scores between the control and treatment groups, $Q(1)=.962, p=.327$.

As with the previous content areas, the results of the multivariate linear regression analysis do not reveal any significant interactions. Results for the regression analysis by time cluster are displayed in Table 16.

Table 16

Standardized Beta Coefficients ( $\beta$ ) for Regression Models of Social Studies Scaled Scores by Time Cluster

\begin{tabular}{|c|c|c|c|c|c|}
\hline \multirow[b]{2}{*}{ Time Cluster } & \multicolumn{3}{|c|}{ Model with interaction } & \multicolumn{2}{|c|}{ Model without interaction } \\
\hline & Time & Group & Interaction & Time & Group \\
\hline 1 & -0.120 & $.273 *$ & 0.187 & -0.014 & 0.161 \\
\hline 2 & 0.235 & $-.332 * *$ & -0.059 & 0.197 & $-.309 * *$ \\
\hline 3 & $.601 *$ & 0.312 & -0.601 & $.558 * *$ & $.323^{*}$ \\
\hline 4 & $.439 *$ & 0.151 & -0.166 & $.322 *$ & 0.151 \\
\hline
\end{tabular}


Results disclose a significant difference across groups for the first two time clusters and across time for the last two time clusters. Group differences exhibited for time clusters 1 and 2 occur during both the pre-treatment and treatment time periods. The differences across time found in time clusters 3 and 4 take place for both groups with higher scores achieved during the treatment period. Graphs of the social studies scores across time for each cluster can be seen in Appendix I.

\section{Writing.}

Similar to the findings for the other four content areas, a meta-analysis of the writing scores for the entire sample $(n=48)$ indicates $Q(1)=.214, p=.644$ with no significant differences between the control and treatment groups across pre-treatment and treatment periods.

The results for a regression analysis of the writing scores by time cluster are shown in Table 17.

Table 17

Standardized Beta Coefficients ( $\beta$ ) for Regression Models of Writing Scaled Scores by Time Cluster

\begin{tabular}{|c|c|c|c|c|c|}
\hline \multirow[b]{2}{*}{ Time Cluster } & \multicolumn{3}{|c|}{ Model with interaction } & \multicolumn{2}{|c|}{ Model without interaction } \\
\hline & Time & Group & Interaction & Time & Group \\
\hline 1 & $-.351 * *$ & 0.233 & 0.156 & $-.263 * *$ & 0.139 \\
\hline 2 & -0.134 & -0.216 & 0.039 & -0.108 & $-.231 *$ \\
\hline 3 & -0.123 & 0.083 & 0.008 & -0.117 & 0.081 \\
\hline 4 & -0.188 & 0.094 & -0.239 & $-.357 *$ & 0.094 \\
\hline
\end{tabular}


The results indicate no significant interaction as displayed in Table 17. Differences across time are significant for both models in time cluster 1 and for the second model in time cluster 4 . The $\beta$ s are negative in each instance, indicating that writing scores are decreasing over time for both of these time clusters. Results also reveal a significant difference in the two groups for time cluster 2 that occurs between the two periods of testing. Graphical representations of the writing scores across time are presented in Appendix J.

\section{Achievement disaggregated by subgroup.}

Mean scaled scores were disaggregated by subgroup and then examined as a composite, by content area, and then by time cluster to answer the research questions below.

4. Does the effect of 1:1 computing vary by demographic group?
a. Gender;
b. Race;
c. Disability status; and
d. Economic status.

3. Does the longevity of the 1:1 program influence the effect it has on student achievement?

\section{Gender.}

As reported earlier in Table 8, a large significant correlation exists between scaled scores for the total group and the female subgroup, between the total group and the male subgroup and between the female and male subgroups. According to Tabachnick and Fidel (2013), if the correlation between two variables approximates .90 or greater, these 
variables should be treated as singular. Therefore, additional analysis of achievement scores, disaggregated by gender, was not performed.

\section{Race.}

Evaluation of the data by subgroup required the use of a factorial analysis of variance (ANOVA) due to limited availability of data. Several schools did not have a sufficient number of students to report scores by race other than for the White subgroup, for the special education students on Individual Education Plans (IEP) or for the economically disadvantaged (ED) students. When data were available for the various subgroups, it was inconsistently reported across all five to eight years of the study for some schools.

Mean scaled scores were investigated for overall performance (all content areas combined) and then broken down by content area and by time cluster. The analysis examined the achievement of the White subgroup, the Black subgroup and all other subgroups combined (Other Combined subgroup). The Hispanic subgroup was combined with the Other subgroup due to the small number of data points for the Hispanics $(n=25$ for the control group and $n=60$ for the treatment group) before the sample was broken down by content area or time cluster. Data were assessed for an interaction effect between group and period (pre-treatment vs. treatment) and then for a main effect for group and period.

Examination of the ANOVA results for the overall performance of the students reveals no significant interaction effects between group and period for any of the racial subgroups. Significant findings were generated for the main effect of period on achievement scores in the White subgroup, $F(1,1396)=5.36, p=.021$, the main effect 
of group on achievement scores in the Black subgroup, $F(1,189)=14.84, p<.001$, and the main effect of group, $F(1,343)=9.37, p=.002$, and period, $F(1,343)=5.28, p=$ .022 on achievement scores for the Other (Combined) subgroup. Refer to Appendix K for complete results of the ANOVA.

A similar analysis of each subgroup was performed for the five content areas. Student performance did not result in a significant interaction effect for any of the subgroups in the five content areas. The main effect of period on achievement scores was significant for the White subgroup in reading, $F(1,276)=4.05, p=.045$, science, $F(1$, $276)=4.59, p=.033$, and social studies, $F(1,276)=4.29, p=.039$. The main effect of group on achievement scores was significant for the Black subgroup in reading, $F(1,35)$ $=7.74, p=.009$, and science, $F(1,35)=5.67, p=.023$. Main effects are significant in the Other (Combined) subgroup for period on achievement scores in math, $F(1,66)=$ 4.49, $p=.038$, and for group on achievement scores in writing, $F(1,66)=9.38, p=.003$. Complete results for the ANOVA by subgroup, by content area, are displayed in Appendix K.

Student performance for each of the subgroups was also examined by implementation time cluster. There is a significant interaction effect between group and period on achievement scores for the Other (Combined) subgroup in time cluster 4 with $F$ $(1,106)=9.70, p=.002$. Achievement means are reported in Table 18 for both groups across the two testing periods. 
Table 18

Means by Treatment Period for Other (Combined) Racial Subgroup

\begin{tabular}{|c|c|c|c|c|c|c|}
\hline \multirow[b]{2}{*}{ Time } & \multirow[b]{2}{*}{ Group } & \multirow[b]{2}{*}{$n$} & \multicolumn{2}{|c|}{ Pre-Treatment Period } & \multicolumn{2}{|c|}{ Treatment Period } \\
\hline & & & $M$ & $S D$ & $M$ & $S D$ \\
\hline \multirow[t]{2}{*}{4} & Control & 20 & 416.87 & 7.49 & 427.40 & 8.09 \\
\hline & Treatment & 20 & 430.40 & 10.87 & 429.48 & 8.60 \\
\hline
\end{tabular}

As displayed in Table 18, the treatment has a negative impact on performance for students in the Other (Combined) subgroup. Achievement scores during the treatment period for the treatment group decrease by .92 while they increase by 10.53 for the control group.

The main effect of group on achievement scores was significant for the White subgroup in time cluster $1, F(1,596)=4.27, p=.039$, time cluster $2, F(1,596)=12.77$, $p<.001$ and for period in time cluster $3, F(1,596)=7.88, p=.006$. Main effects are significant in the Black subgroup for time cluster 4 for both group, $F(1,86)=39.87, p<$ .001 , and period, $F(1,86)=7.77, p=.007$. The main effect of group on achievement scores is significant for the Other (Combined) subgroup in time cluster $2, F(1,120)=$ 9.87, $p=.002$. Complete results for the ANOVA by subgroup, by time cluster, are displayed in Appendix K.

\section{Disability status.}

Similar to racial subgroups, a factorial analysis of variance (ANOVA) was conducted to assess whether the impact of 1:1 computing programs is influenced by disability status. Students with disabilities are given Individual Education Plans and are reported as IEP students. 
Examination of the ANOVA results for the overall and specific content area performance of the students indicates there is not a significant interaction effect between group and period for IEP students. There is, however, a significant main effect of period on overall student achievement in the composite sample, $F(1,721)=8.34, p=.004$. The main effect of period on achievement scores was significant for the IEP subgroup in reading, $F(1,141)=5.67, p=.019$, and social studies, $F(1,141)=5.58, p=.020$.

A significant interaction effect between group and period on achievement scores occurs in time cluster 1 with $F(1,333)=4.15, p=.042$ and time cluster $4, F(1,121)=$ $6.02, p=.016$. Achievement test means for the two time clusters are reported in Table 19.

Table 19

Means by Period for Students with Disabilities (IEP) Subgroup

\begin{tabular}{|c|c|c|c|c|c|c|c|}
\hline \multirow[b]{2}{*}{ Time } & \multirow[b]{2}{*}{ Group } & \multicolumn{3}{|c|}{ Pre-Treatment Period } & \multicolumn{3}{|c|}{ Treatment Period } \\
\hline & & $n$ & $M$ & $S D$ & $n$ & $M$ & $S D$ \\
\hline \multirow[t]{2}{*}{1} & Control & 137 & 397.07 & 7.61 & 30 & 399.38 & 7.49 \\
\hline & Treatment & 140 & 397.99 & 9.83 & 30 & 395.35 & 6.50 \\
\hline \multirow[t]{2}{*}{4} & Control & 30 & 399.32 & 8.33 & 25 & 404.24 & 5.83 \\
\hline & Treatment & 40 & 408.56 & 8.06 & 30 & 406.17 & 9.80 \\
\hline
\end{tabular}

Achievement scores during the treatment period are less than pre-treatment scores for the treatment group in both time clusters. The 1:1 program has a negative influence on IEP students in these two time clusters as indicated by a decrease of 2.63 in cluster 1 and a by 2.39 in cluster 4.

Main effects are significant in time cluster 3 for group on achievement scores, $F$ $(1,66)=37.28, p<.001$, and for period on achievement scores, $F(1,66)=15.13, p<$ 
.001. The main effect of group on achievement scores was significant for the White subgroup in time cluster $1, F(1,596)=4.27, p=.039$. Refer to Appendix L for results of the ANOVA for IEP students.

\section{Economic status.}

Similar to the previous subgroups, a factorial analysis of variance (ANOVA) was conducted to assess whether the impact of 1:1 computing programs is influenced by economic status. Scaled scores are not reported by the ODE for economically disadvantaged (ED) students so student achievement for this subgroup was measured using the percentage of students that score proficient or above. Since these data are reported as percentages, the data range is naturally truncated between 0 and 1.0.

Examination of the ANOVA results for the overall performance of the ED students reveals no significant interaction effect between group and period on proficiency rates. Further examination of the composite data indicates a significant main effect of period on proficiency rates, $F(1,1006)=8.13, p=.004$.

When observed by content area and time cluster, interaction effects between group and period on proficiency rates are not significant. Significant main effects occur for period in reading, $F(1,198)=4.57, p=.034$ and for time cluster $4, F(1,156)=5.24$, $p=.023$. ANOVA results for the ED subgroup are displayed in Appendix M.

\section{Achievement broken down by 1:1 computing device.}

Mean scaled scores for the treatment group only are being analyzed as a composite (all five areas combined) and by content area to answer the research question below. 
3. Does the type of device used by the students (laptop, netbook, or tablet) influence the effect 1:1 computing has on student achievement?

Meta-analysis of all the test scores was performed to determine if overall achievement varied within and between the three types of devices being implemented by schools in the treatment group. The standardized differences in means $(d)$ for the three devices are reported in Table 20.

Table 20

Standardized Difference in Means by Device

\begin{tabular}{llllll}
\hline & & & & \multicolumn{2}{c}{$95 \% \mathrm{CI}$} \\
\cline { 5 - 6 } Device & $n$ & $d$ & $\mathrm{SE}$ & $\mathrm{LL}$ & $\mathrm{UL}$ \\
\hline Laptop & 45 & 0.33 & 0.22 & -0.098 & 0.765 \\
Netbook & 35 & $0.96^{* *}$ & 0.25 & 0.467 & 1.445 \\
$\mathrm{iPad}$ & 40 & 0.32 & 0.23 & -0.134 & 0.781 \\
\hline $\begin{array}{l}\text { Note. CI }=\text { Confidence Interval; LL }=\text { Lower limit; UL }=\text { Upper limit } \\
* p<.05, * * p<001\end{array}$
\end{tabular}

Treatment schools using netbooks displayed a significant difference in test scores between the pre-treatment and treatment periods. Further examination of the data indicates that the greatest increase in test scores took place in math $(+3.53)$ followed by science and social studies $(+2.20)$. The change in test scores for all three devices can be seen in Table 21 while the CMA outputs with composite and content specific means are displayed in Appendix N. 
Table 21

Pre-Treatment to Treatment Period Change

\begin{tabular}{llll}
\hline Content & Laptop & Netbook & iPad \\
\hline Math & 2.41 & 3.53 & 1.37 \\
Reading & 2.38 & 1.47 & 0.68 \\
Science & 1.37 & 2.20 & 2.20 \\
Social Studies & 4.07 & 2.20 & -0.61 \\
Writing & -3.89 & -1.17 & -2.12 \\
Composite & 1.27 & 1.65 & 0.26 \\
\hline
\end{tabular}

Despite revealing a significant difference in test scores between the two periods when using a netbook, the gain of 1.65 points is very small when using a scale that ranges from approximately 200 to 600 points. There is not a significant difference in achievement test scores when comparing the use of the three devices, $Q(2)=4.469, p=.107$

An ANOVA was also conducted for the composite test scores and each content area separately. Data were assessed for an interaction effect between device and period (pre-treatment vs. treatment) and then for a main effect for device and period.

Examination of the ANOVA results yield no significant findings for interaction or main effects for the composite sample or any of the five content areas. ANOVA results for each device are provided in Appendix N.

\section{Additional Findings}

Data were analyzed at the pair level using IPD meta-analysis to identify treatment schools that significantly outperform the paired control school in multiple content areas. Table 22 lists the treatment schools that performed significantly different than the control 
schools in at least three of the five content areas. A table summarizing the between group effects (Q) for all five content areas is broken down by pair in Appendix O.

Table 22

Pairs with Significant Qs across Multiple Content Areas

\begin{tabular}{|c|c|c|c|c|c|c|c|c|}
\hline Pair & \# of Areas & $\mathrm{M}$ & $\mathrm{R}$ & $\mathrm{S}$ & $\mathrm{SS}$ & W & Cluster & Device \\
\hline \multicolumn{9}{|c|}{ Positive effects } \\
\hline 9 & 4 & $\mathrm{~T}$ & $\mathrm{~T}$ & & $\mathrm{~T}$ & $\mathrm{~T}$ & 1 & Netbook \\
\hline 18 & 4 & $\mathrm{~T}$ & $\mathrm{~T}$ & $\mathrm{~T}$ & $\mathrm{~T}$ & & 2 & Laptop \\
\hline 2 & 3 & $\mathrm{~T}$ & & $\mathrm{~T}$ & & $\mathrm{~T}$ & 1 & Laptop \\
\hline 7 & 3 & & $\mathrm{~T}$ & & $\mathrm{~T}$ & $\mathrm{~T}$ & 1 & Netbook \\
\hline 21 & 3 & $\mathrm{~T}$ & $\mathrm{~T}$ & & & $\mathrm{~T}$ & 3 & Laptop \\
\hline \multicolumn{9}{|c|}{ Negative effects } \\
\hline 5 & 5 & $\mathrm{C}$ & $\mathrm{C}$ & $\mathrm{C}$ & $\mathrm{C}$ & $\mathrm{C}$ & 1 & Netbook \\
\hline 23 & 5 & $\mathrm{C}$ & $\mathrm{C}$ & $\mathrm{C}$ & $\mathrm{C}$ & $\mathrm{C}$ & 4 & Laptop \\
\hline 13 & 4 & $\mathrm{C}$ & $\mathrm{C}$ & $\mathrm{C}$ & $\mathrm{C}$ & & 2 & Netbook \\
\hline 1 & 3 & $\mathrm{C}$ & & $\mathrm{C}$ & $\mathrm{C}$ & & 1 & iPad \\
\hline 17 & 3 & $\mathrm{C}$ & $\mathrm{C}$ & $\mathrm{C}$ & & & 2 & iPad \\
\hline
\end{tabular}

Mixed effects

$\begin{array}{llllllll}11 & 4 & \mathrm{C} & \mathrm{C} & \mathrm{C} & \mathrm{T} & 1 & \text { Netbook }\end{array}$

Note. T indicates the treatment group significantly outperformed the control group. C indicates the control group significantly outperformed the treatment group. Cells are blank where there is not a significant difference in the achievement scores for the two groups. M - Math, R - Reading, S Science, SS - Social studies and W - Writing.

Five treatment schools (T2, T7, T9, T18, and T22) have a positive, significant impact on student test scores in at least three content areas. As seen in Table 22, higher student performance occurs at the treatment schools an equal number of times in math, reading, and writing. These schools are spread across three of the four time clusters $(1,2$, and 3) with students using either laptops or netbooks for the 1:1 program. Drilling deeper 
into the data for these five treatment schools reveals large effect sizes across multiple content areas for three treatment schools. The 1:1 program in T21 generated effect sizes of $d=4.99$ in math, $d=4.42$ in reading, and $d=3.30$ in science. T21 was also one of five treatment schools that had a positive effect on writing scores with $d=.94$. T9 also generated large effect sizes in math $(d=5.25)$, science $(d=8.91)$, and social studies $(d=$ 2.30). T2 had effect sizes of $d=3.02$ and $d=1.93$ in math and science respectively.

Five treatment schools display a significant, negative effect on student achievement across multiple content areas. In particular, two treatment schools (T5 and T23) were outperformed by the control school across all five content areas. Schools with 1:1 programs including T13 (four areas), T1 (three areas), and T17 (three areas) were also outperformed by their control schools. The five treatment schools with negative effects

on student performance are spread across three time clusters $(1,2$, and 4$)$ and use all three types of devices in the study.

Rather than having a consistently positive or negative effect on student achievement, several treatment schools reveal significant $Q$ values in both directions. Only one treatment school (T11) reveals significantly different results for the two groups across four content areas while eight treatment schools had mixed results across three areas.

\section{Summary}

Chapter four explores OGT test data at the aggregate, time cluster, and pair level to study the effect that 1:1 computing programs have on overall and content specific achievement in math, reading, science, social studies, and writing. 
Descriptive analysis reveals that the PI scores for the treatment and control groups are equivalent. When broken down by implementation time cluster, results vary across the clusters where scores are larger for the treatment group in time clusters 1 and 3 , the control group in cluster 2, and are the same for cluster 4.

Descriptive statistics for the mean scaled scores in the five content areas indicate that the control group has higher achievement scores in math, reading, and science, while the achievement scores for both groups are equivalent in social studies and writing. When mean scores for the two groups are examined by content area and time cluster, the only consistent pattern emerges in time cluster 2 where the control group scores are higher across all five content areas.

Descriptive analysis of the demographic subgroups discloses essentially the same mean scores for both genders across both groups. A general pattern of performance exists when observing achievement scores across groups with the White subgroup > Blacks $>$ Other $>$ Hispanics. The treatment group has higher scores for the Hispanic and Other subgroups, the control group outperforms the treatment group for the Black subgroup, and both groups have similar performance in the White subgroup. The treatment group has higher scores for IEP students and results are mixed across the five content areas for ED students.

Zero-order correlations were performed across demographic subgroups revealing large, positive correlations that suggest singularity between the total group, males, and females. Moderate correlations exist between all of the racial subgroups with the exception of the correlation between Blacks and Hispanics. 
Data analysis of the overall achievement scores using the PI indicates no significant differences between the two groups for the composite sample. However, when broken down by time cluster, PI scores are significantly greater for the control group in time cluster 3 .

Investigation of the mean scaled scores across the five content areas reveals no significant difference in the treatment and control groups for any of the content areas. Disaggregation by time cluster reveals no significant differences using regression analysis, while meta-analysis indicates that the treatment group performed significantly higher in reading time cluster 3 and science cluster 1.

Gender was not analyzed any further due to the issue of singularity identified in the zero-order correlation. When racial subgroups and IEP students are examined with an ANOVA, there are no significant differences between the control and treatment groups for overall or content specific performance. When divided into implementation time clusters, results reveal a significantly higher performance for the control group in time cluster 4 for the Other (Combined) subgroup and IEP students. The control group significantly outperforms the treatment group for IEP students in time cluster 1 as well. There are no significant findings for the ED subgroup.

Test scores were compared for treatment schools based on the computing devices used by the students. A meta-analysis of OGT scores for all five content areas divulges students using netbooks have significantly higher gains in test scores between the pretreatment and treatment periods. An ANOVA reveals no significant interaction between the device used and time. 
Additional analysis of the achievement scores was conducted at the pair level to identify patterns across multiple content areas. Five treatment schools (T2, T7, T9, T18, and T21) have a positive, significant impact on student test scores in at least three content areas, five treatment schools (T1, T5, T13, T17 and T23) have a significant, negative effect, and one treatment school (T11) has significant, but mixed effects, in at least four of the five content areas. 


\section{Chapter 5}

\section{Discussion}

The general purpose of the current investigation is to examine the effect that $1: 1$ computing programs have on student achievement. Evidence is insufficient to reject the null hypothesis (1:1 computing does not impact student achievement) as statistical testing indicates no significant difference in test scores between the treatment schools and the control schools. More specifically, the study addresses five research questions. Chapter five summarizes the findings for each research question and briefly discusses each outcome in the context of current research. This chapter also includes a set of conclusions that can be drawn from the results of the dissertation, limitations of the study, recommendations for future research, and implications for practice.

Findings for each research question are summarized and discussed below.

\section{Research Question 1: Does implementation of a 1:1 computing environment in Ohio high schools affect student achievement?}

Overall achievement, as measured by the performance index score on the OGT, does not exhibit a statistically significant difference for students participating in 1:1 computing programs when compared to student scores for similar high schools without a 1:1 program. Previous research that found significant differences in overall achievement used alternate measures of student performance including cumulative grade point average for middle school students in California (Gulek \& Demirtas, 2005; Lei, 2010a; Lei \& Zhao, 2008), and homework and quiz grades for college students (Enriquez, 2010). The

grades documented on student report cards often reflect effort and behavior in addition to student knowledge and may not be the most accurate measure of student achievement (Guskey, 2009). This is the first known study to utilize performance index scores as the 
measure of overall student achievement when studying the impact of 1:1 computing programs. Additional studies that use PI as a measure of overall achievement would be beneficial in answering this question by providing the data necessary to formulate any generalizations about the relationship between 1:1 computing programs and overall achievement.

\section{Research Question 2: Does the effect of 1:1 computing, as measured by test scores on the Ohio Graduation Test (OGT), vary by content area including math, reading, science, social studies, and writing?}

Schools with one-to-one computing programs did not display any significant difference (positive or negative) in OGT scaled scores for any of the five content areas that were analyzed for the current investigation. As discussed in the literature review, previous large scale research studies in several states resulted in mixed findings regarding the impact of 1:1 laptop programs on student achievement in math. Results varied anywhere from a statistically significant positive impact on math scores to a significantly negative affect on math scores (Bebell \& Kay, 2010; Gulek \& Demirtas, 2005; Holcomb, 2009; Huntley \& Greever-Rice, 2007; Mann, 2008). The composite results in the current investigation reveal a slight, but non-significant increase in math scores for schools with a 1:1 computing program. If scores are examined at the pair level, the same pattern found in previous research emerges with some 1:1 schools achieving significantly increased math scores $(6 / 24)$, some attaining no change in scores $(11 / 24)$, and others demonstrating a significant decrease in scores (7/24). Previous research suggests that the wide range in impact of 1:1 computing for test results in math is related to the frequency of use (Bebell \& Kay, 2010; Mann, 2008) and the need for content-specific, professional development 
for math teachers to successfully implement technology into their lessons (Silvernail, 2008).

OGT reading scores were not significantly different for 1:1 and non-1:1 schools in the current investigation, which is consistent with an earlier study done in Texas (Ganner, 2008), but, inconsistent with studies in several other states. Shapely et al. (2010) concluded that both math and reading scores in Texas were not significantly different after four years due to minimal implementation and use of the laptops in core (English, math, science, and social studies) classrooms. Reading results are similar to math outcomes when data are analyzed at the pair level with regard to significant differences in achievement scores. The treatment group achieved higher scores in five pairs, the control group attained higher scores in nine pairs, and there was no statistical difference between the two groups in ten pairs. A noteworthy observation in this content area regarding the devices used in the treatment schools: none of the five treatment schools that outperformed the control schools are using an iPad as the device for their 1:1 program while five of the nine treatment schools that were outperformed by the control schools have students using iPads.

The lack of significant findings for science and social studies test scores is not surprising considering the non-significant findings in math and reading which are emphasized and more frequently assessed in schools as required by No Child Left Behind legislation. Results cannot be compared with the limited studies done previously at the elementary level in both content areas and in science at one middle school. Science results had the smallest number (four) of treatment schools outperforming the control schools when examined at the pair level. Social studies results display the greatest 
dichotomy with only four of the paired schools having no significant difference in results, 11 treatment schools performing significantly higher than the control schools, and nine control schools outperforming the 1:1 schools.

Previous studies have identified writing as the area that is most positively impacted by the implementation of 1:1 laptop programs, making the non-significant

finding in the current investigation contrary to what was expected. Although eight of the 24 treatment schools significantly outperformed the matched control school, mean writing scores decreased from the pre-treatment to the treatment period for 19 treatment schools and 19 control schools. This pattern of declining scores also held true when examining state-wide writing mean scores for a similar time period (ODE, 2004c). Although not significant, writing scores declined less for treatment schools than for the control schools.

As was noted earlier, most of the previous studies regarding 1:1 computing took place at the middle school level using laptops. In a recent meta-analysis of 58 studies, Lee et al. (2013) found that the integration of technology has the smallest mean effect (.22) at the high school level when compared to grades K-3 (.50), 4-6 (.41), and 7-8 (.59). Research Question 3: Does the longevity of the 1:1 program influence the effect it has on student achievement?

When the data is examined by time cluster (longevity of 1 to 4 years for program implementation), there are several arbitrary instances where one of the groups achieves significantly better results than the other group. There is no clear pattern established for instances where the treatment group performs higher than the control group. Despite any 
statistically significant findings, the results are not particularly meaningful because of the small gain in test scores.

Treatment groups significantly outperformed the control group in two instances when the data are examined by content area. For science, in time cluster 1, the treatment (T) group gained 2.2 points while the control (C) group gained only .7 points. Reading scores in time cluster 3 are significantly higher for the treatment group $(+5.9)$ than for the control group $(+4.5)$ with the pattern of the $\mathrm{T}>\mathrm{C}$ holding true for both pairs in this time cluster.

There are four instances where $\mathrm{C}$ significantly outperforms $\mathrm{T}$ when examining the data as a composite and by demographic subgroup. The difference occurs in time cluster $3, \mathrm{C}(+2.6)>\mathrm{T}(+1.0)$ when looking at overall performance. When data are disaggregated by various demographic subgroups, there are three instances where $\mathrm{C}$ significantly outperforms $\mathrm{T}$ with scores declining over time for the treatment group and increasing over time for the control group. When disaggregated by race, results for the Other (combined) group reveal C $(+10.5)>\mathrm{T}(-.9)$ in time cluster 4 . This 11.4 point difference in mean test scores between the two periods is notable, with a similar pattern occurring in cluster 4 for the IEP subgroup. As discussed earlier, the Other (combined) subgroup is unique for this research study as results were combined into one group for all racial subgroups exclusive of the White subgroup and the Black subgroup. Due to the formation of this unique subgroup, results cannot be compared to previously published research studies.

Results for the IEP subgroup reveal significant differences in two time clusters. In time cluster 1, results demonstrate $\mathrm{C}(+2.2)>\mathrm{T}(-2.6)$ with a difference of 4.8 points. 
Performance in cluster 4 shows $\mathrm{C}(+4.9)>\mathrm{T}(-2.4)$ with a difference of 7.3 points. These findings are contrary to previous research for IEP students who demonstrated significantly positive results in writing when participating in 1:1 computing programs (Goldberg, Russell, \& Cook, 2003) and no significant impact in math (Huntley \& Greever-Rice, 2007). When examined by time cluster, test scores are a composite value for all five content areas in the current investigation and, therefore, may account for the difference in outcomes compared to previous studies that are reported by specific content area.

\section{Research Question 4: Does the effect of 1:1 computing vary by demographic group, including gender, race, disability status, and economic status?}

ANOVA tests for the three racial subgroups, the IEP subgroup, and the ED subgroup yield no significant interactions between the group (treatment or control) and period (pre-treatment and treatment) when examining test scores as a composite or by specific content area. There are several significant findings for a main effect of group or period, but they are not relevant to this research question. As noted earlier in Chapter 4, gender was not examined due to the issue of singularity with the scaled scores for the total sample. When examining a 1:1 laptop program for third through sixth grade students in Missouri, results revealed that participation in the program resulted in a significantly positive impact on test scores in math and communication arts for all students and various demographic subgroups other than IEP students and Blacks (Huntley \& Greever-Rice, 2007). Subgroups' results are analogous to the overall sample in the current investigation (neither yielding significant findings) which is similar to the pattern in the Missouri study. 


\section{Research Question 5: Does the type of device used by the students (laptop, netbook, or tablet) influence the effect 1:1 computing has on student achievement?}

Treatment schools using netbooks in their 1:1 computing program display a significant gain from the pre-treatment to treatment test scores. The composite gain of 1.65 points for schools using netbooks, although statistically significant, is not particularly notable or that much greater than the gain for treatment schools using laptops $(+1.27)$. When gains are examined by content, netbook school results produced the largest gain in math $(+3.53)$ followed by science and social studies $(+2.20$ for both). The largest positive change occurred in social studies $(+4.07)$ with schools using laptops.

Writing scores decreased over time for the treatment schools using all three devices, as well as the control schools. One-to-one programs using a netbook have the smallest decline $(-1.17)$ when compared to other programs using laptops $(-3.89)$ or iPads (-2.12). When comparing user satisfaction and preferences with mobile devices, Ozok, Benson, Chakraborty, and Norcio (2008) found college students significantly preferred a laptop to a tablet when completing a writing assignment. Students indicated that use of the tablet required significantly more mental effort and a longer time to complete a writing task. Using a laptop was more convenient when typing and resulted in greater accuracy than when using a tablet. Students, however, preferred the mobility and portability of the tablet. The netbook provides the advantages of both devices with an external keyboard (similar to a laptop) and the mobility of a tablet (smaller and lighter than a laptop). 


\section{Conclusion}

An analysis of test scores for the entire sample of 48 high schools reveals no significant difference in student achievement when comparing the change in test scores from the pre-treatment to the treatment period for the two groups. Significant findings start to occur, however, as data are broken down into smaller units. As information is examined by implementation time cluster or by pair in particular, there is less variability in the factors that impact the success of a 1:1 program and statistically significant differences begin to emerge in both directions $(\mathrm{T}>\mathrm{C}$ and $\mathrm{C}>\mathrm{T})$. The emergence of these findings with results going in opposite directions may be explained by variations in the intended goals of the 1:1 computing program, implementation support and fidelity, plus, the potential for outside factors to impact student test scores.

"Schools have often been uncertain about the outcomes they want to achieve with technology" (Protheroe, 2005, p. 47). Improving student achievement is only one of several goals reported for 1:1 computing programs in the past. Other goals that are frequently cited for 1:1 programs include providing equity of access, enhancing economic competitiveness, transforming learning, and mastery of real life skills for the $21^{\text {st }}$ century (Penuel, 2006; Richardson et al., 2014: \& Zucker, 2004). If the intended purpose of a 1:1 program is not improved student achievement, then it is unlikely that implementation of such a program will result in this desired outcome. The transformation of learning is one goal that is closely linked to student achievement. As teachers implement technology into the classroom, Puentedura (2009) identified four distinct methods (substitution, augmentation, modification, and redefinition) that teachers use to implement technology that have a direct impact on learning outcomes. Substituting a mobile device for the use 
of a pencil, without any functional change in the desired learning outcome, will not affect student achievement. As Protheroe (2005) suggested, "Finding ways that computers can help educators teach the same old things in the same old ways will not impact learning" (p. 48). Using technology to design a task that mimics a real life problem and requires critical analysis of several concepts (modification or redefinition) would require transformation of learning and produce higher levels of learning.

Over the past 20 years, teachers have consistently identified three barriers to technology implementation including lack of access to computers, insufficient funding, and a lack of training (Okolo \& Diedrich, 2014). The treatment schools in the current investigation overcame the first barrier, and, at least, partially addressed the second barrier by providing each student and teacher with a personal device. Specific levels of preparation, implementation, and support were not examined in the current investigation; therefore, there is no way to determine if the treatment schools completely overcame the funding or training barriers. To fully implement technology into the classroom, teachers identified the need for training in several areas including technology awareness and skills, changing teacher attitudes and beliefs, and improving teacher knowledge of teaching and learning.

Zucker's (2004) framework for research on 1:1 computing, which was cited previously in Figure 1 (p. 22), provides a visual model of how the critical features (inputs) of a program, the intermediate outcomes (implementation factors), and the ultimate outcomes (student learning) are related to one another. According to his framework, the purpose of the program (goals) and training will directly impact multiple implementation variables such as leadership, parent, community, and technical support, 
and the quality of instruction. Implementation, or treatment fidelity, is the link between the $1: 1$ computing program (intervention) and the change in student outcomes. Knowing the extent to which an intervention is implemented can help determine if a lack of change in student outcomes is due to an ineffective intervention program or an intervention that was not fully implemented (Collier-Meek, Fallon, Sanetti, \& Maggin, 2013).

In education, treatments (interventions) tend to be multi-dimensional, involving not just what and how long the intervention takes place, but also how well it was implemented. Harn, Parisi, and Stoolmiller (2013) divided implementation fidelity into two dimensions - structural and procedural. The structural dimension examines whether the various components of an intervention are delivered with measures such as time allotment, frequency, and number of lessons. The procedural dimension is the quality of the delivery and is measured with the nature and quality of the interactions between the teacher and the students. They found significant variation in both dimensions across multiple school sites and determined that learning outcomes for different content areas were best predicted by different implementation dimensions, suggesting that implementation fidelity is a complex and dynamic concept.

Two recent studies attempted to quantify the impact of various factors on the implementation fidelity of technology in classrooms. Inan and Lowther (2010) used a path model to determine that teacher readiness, teacher beliefs, and computer availability have a significantly positive and direct effect on technology integration (the frequency of technology use as measured by teacher perception). Indirect effects (in descending order of influence) include the computer proficiency of the teacher, overall support (administrators, peers, parents combined), and technical support. This investigation 
focused on the structural dimensions of implementation and did not address the quality of delivery or any changes in pedagogy.

Shapley et al. (2010) studied the association between implementation fidelity and student achievement in 21 Texas middle schools (grades $6-8$ ) that participated in the state initiated Technology Immersion Pilot for four years. They used both a rubric and the results from teacher and student questionnaires to place every school into one of four levels of immersion (minimal, partial, substantial, or full). The seven implementation variables that were measured in the study, based on the framework published earlier by Zucker (2004), include immersion support by leadership, teachers, parents, technology staff and professional development, classroom immersion, and student access and use, as displayed in Figure 2 below. (Refer to Appendix P for a description of each variable). Each variable was then compared to student performance on the state achievement test in reading and math to determine the degree to which each factor impacts student achievement when implementing a 1:1 laptop program. 
Immersion Support

^1. Leadership+o

^2. Teacher Support

3. Parent Support

4. Technical Support

$\wedge 5$. Professional Development
6. Classroom Immersion

Tech. Integration+ Learner Centered Act.+ Student Activities Communication Professional Productivity

\section{Student Access \&} Use*

\# of Access Days Use in Core Content Home Learning*

* Positive predictors of test scores

^ Identified as KEYS to success

by high implementation schools

+ Leaders stated purpose for technology

is to transform learning

o Collaboratively developed an implementation plan

Figure 2. Measures of implementation fidelity for the Technology Immersion Pilot. (Shapely et al., 2010.)

Only four of the 21 schools in the study attained at least a substantial level of immersion in the core content areas after four years, which shed light on the inconsistent results that were previously reported for the impact of the 1:1 pilot program on student test scores. The study found a positive correlation between the level of immersion and the impact that 1:1 programs have on student test scores. They also discovered that the only implementation factors that are significantly positive predictors of student test scores on the Texas Assessment of Knowledge and Skills (TAKS) in reading and math are the aggregate measure of student access and use, and the individual measure of student use for home learning. The immersion support and classroom immersion 
variables were measured using teacher questionnaires, while student access and use levels were determined using the results of student surveys. Teacher reported levels of classroom immersion were often inconsistent (higher in most cases) with student perceptions of classroom use. Researchers offered a cautionary note to anyone drawing conclusions from implementation data collected exclusively from teachers.

The four schools with the highest levels of immersion identified several keys to their implementation success including committed leaders, thorough planning, preliminary professional development, teacher buy-in, and a commitment to use the technology to transform learning. The high implementation schools also discovered that not having a start-up year for planning and teacher training was a major barrier to effective implementation of 1:1 computing, which supports the conclusion in the Inan and Lowther (2010) study that teacher readiness has the greatest impact on technology implementation.

Similar to the large scale study of 1:1 laptop programs in Texas, results for the current investigation examining Ohio high schools is influenced by the implementation fidelity of each treatment school. As cited earlier, both the structural and procedural dimensions of implementation fidelity effect learning outcomes and, ultimately, impact student test scores. This may be one explanation for some of the patterns that emerged when examining the results by pair, where several treatment schools attained positive gains in test scores following the implementation of 1:1 computing programs while others had negative outcomes. Both Zucker (2004) and Shapley et al. (2010) display their models in a linear framework where adult implementation factors precede student use and impact on learning. Ultimately, students must attain deep levels of implementation and 
ubiquitous use of technology before test scores will be significantly impacted (Shapley et al., 2010).

In addition to the role that program goals and implementation fidelity play in the outcomes of the current investigation, there are many factors outside the use of technology that influence learning and, therefore, may explain changes in student test scores over time.

\section{Limitations}

There are multiple variables that impact student learning and, consequently, affect achievement test scores. A closely controlled experimental design is difficult, if not impossible, to attain in an educational setting. Drawing any conclusions regarding a single cause of any change in student achievement, therefore, is not feasible and has limitations.

Some of the factors that influence student achievement outcomes, based on current research, include aligning curriculum and/or instructional materials to content standards and testing outcomes, hiring highly qualified teachers, providing learnerfocused leadership, and utilizing best instructional practices that are independent of technology (Blankstein, 2010). These types of confounding variables are most likely spread across the treatment and control groups, minimizing their impact on the overall results, but still having some influence when data are examined at the pair level.

Alternative explanations for changes in test scores, such as those suggested above, become less notable when patterns that are apparent across multiple content areas, and for longer periods of time, are used to draw any conclusions. Additional threats to internal validity exist (such as a different group of students taking the test each year), but are 
mediated by the use of a research methodology, an Interrupted Time Series in this case, that requires the analysis of multiple years of data prior to and following the introduction of the 1:1 computing program.

A second limitation stems from the lack of data regarding the extent to which students used the 1:1 devices for specific types of learning. In the present investigation, students had access to a mobile device 24/7, but it is not known how often the devices were used during core content classes or at home. This information provides the key link to predicting whether 1:1 computing will impact student test scores (Shapley et al., 2010). Other implementation factors such as support, professional development, and classroom immersion were not assessed for the treatment schools making it impossible to determine any potential relationship between implementation fidelity and the impact each program had on student achievement.

Some additional limitations were created by the sample of schools that voluntarily initiated a 1:1 program. Twenty-one of the 24 treatment schools were rated excellent prior to implementation of the program based on the state issued report card. In some cases, treatment schools had mean scaled scores that were among the best in the state and, therefore, had little room to show growth. Student populations for most of the schools (treatment and control schools alike) were predominately White with a low percentage of economically disadvantaged students. The composition of the sample led to very small sample sizes $(n=2)$ when analysis was conducted for various demographic subgroups.

Each treatment school was paired with a comparable high school based on the similar district methodology deployed by the Ohio Department of Education for public 
schools, while parochial schools were matched by the researcher using demographic statistics. Each district in the current investigation has only one high school so it was assumed that similar districts equated to similar high schools. Each school was paired with the one that was identified as most similar to it for the school year immediately prior to the implementation of a 1:1 computing program. A new list is generated each year and the district that is considered most similar one year may be different the following year. Although accepted as a valid technique for identifying districts that are statistically most similar, the methodology does not include achievement test scores as one of the nine variables used to compare districts. This system does not account for any schools that perform much higher or lower than similar ones with the same demographic composition.

\section{Further Research}

Few studies have specifically tested the link between expected outcomes of a 1:1 program and different implementation levels. Any additional studies that attempt to measure the relationship between 1:1 computing and student achievement should include some measures of implementation fidelity and student use (Penuel, 2006). When investigating the relationship between 1:1 computing and student test scores, study participants should be limited to those districts/schools that have clearly identified the transformation of learning and increased student achievement as the ultimate goal of their 1:1 computing program.

Given the parameters cited above, a follow-up study of a select sample of the 24 treatment schools in the current investigation with the addition of implementation and use measures, similar to those developed by Shapley et al. (2010), would contribute substantially to the body of research on the relationship between 1:1 computing, 
implementation fidelity, and student achievement. March 2014 OGT test scores could be added to the achievement data collected for the current investigation with all 1:1 schools having a minimum of two years of implementation, thus eliminating the influence of either a halo effect or an implementation dip (Lei, 2010b). Selecting treatment schools from the current investigation that exhibit patterns of all positive or all negative effects across multiple content areas would allow the researcher to focus on the impact of school level implementation as well as content specific integration of technology in the classroom.

A study that examines the relationship between various implementation factors of a 1:1 computing program (leadership, support, professional development, classroom immersion, and student use) and student achievement in science, social studies, or writing, would be original research and provide insight into the relationship between 1:1 computing, implementation fidelity, and student test scores in these content areas.

Conducting a case study of T21 and T23 would provide a comparison of 1:1 programs that displayed all positive effects to all negative effects across multiple content areas. Both treatment schools are public schools using laptops for their programs. T21 has had a 1:1 program for three years and $\mathrm{T} 23$ has had a program for four years. The program at $\mathrm{T} 21$ exhibits a significant, positive impact on test scores in three content areas (math, reading, and writing), while the 1:1 program at T23 yields a significant, negative effect on test scores in all five content areas. A case study would allow the researcher to examine implementation fidelity and student impact from a number of perspectives: principals, teachers, students, and parents as was recommended by Inan \& Lowther (2010), and compare similarities and differences across the two schools. 


\section{Implications for Practice}

For a 1:1 computing program to have a positive effect on student achievement, a school must do much more than simply purchase mobile devices and provide students and teachers with access to them 24/7. Mixed results from earlier large scale 1:1 laptop studies, as well as in the current investigation, seem to suggest that implementation fidelity plays a greater role than the type of device or the longevity of implementation when analyzing the impact of 1:1 computing programs on student test scores.

Technology implementation is a complex process that requires a comprehensive approach that transforms school culture, changes the nature of teaching and learning, and expands the boundaries of the school and classroom (Shapley et al., 2010).

The number of high schools implementing 1:1 programs during the 2013-14 school year more than doubled from the previous year with 26 high schools initiating programs this past year. Current circumstances present a unique window of opportunity for schools to implement 1:1 programs, with many of them moving quickly to have programs in place prior to the online state testing that will begin in 2015. Despite these driving forces, school leaders must be well aware of the impact (or lack thereof) that such programs have on student achievement, as well as the multiple factors that influence the success of 1:1 programs. Based on the current research and findings from the current investigation, it would be fitting for schools to consider the following before instituting a 1:1 program.

- Conduct action research by visiting schools that already have a 1:1 program to determine what works and was does not. Data suggest that schools T21 (using laptops in time cluster 3) and T9 (netbooks, cluster 1) would provide the best 
examples of programs with primarily positive results. School T23 (laptops, cluster 4) and either T5 (netbooks, cluster 1) or T1 (iPads, cluster 1) are schools with negative results across multiple content areas that would provide a good comparison to one of the first two schools listed above.

- Develop a comprehensive, multi-year plan for preparation, implementation, and full deployment of a 1:1 computing program that clearly identifies the goals of the program (Penuel, 2006; Protheroe, 2005; Shapley et al., 2010).

- Incorporate one year into the plan for professional development (PD) to build teacher readiness prior to giving devices to the students (Inan \& Lowther, 2010; Protheroe, 2005; Shapley et. al., 2010). PD should focus on how technology can transform learning and develop teachers' abilities to integrate their knowledge of technology with knowledge of content and pedagogy, then transfer it into practice (Scott \& Mouza, 2007) by doing the following:

Enhance teacher understanding of their subject matter with respect to technology;

- Increase teacher experience using technology as learners;

- Improve teacher experience using technology in an instructional setting; and

- Establish a sense of community that can support classroom implementation of technology.

- Set expectations for frequency and type of use in classrooms.

- Monitor adult implementation factors using a survey similar to the one used in the Shapley et al. (2010) study in Texas as well as classroom observations. Do 
not rely solely on teacher-reported classroom immersion as it tends to be higher than student reported use.

- Measure student use of technology (frequency and how it is used) at school and home (for learning).

Leadership, overall support, and professional development are all positively correlated to classroom immersion. Expecting teachers to integrate technology into their lessons is not enough to impact student achievement however. Deep implementation involves student use of the technology at school and home in ways that enhance their learning and is most likely to produce increased test scores (Shapley et al., 2010).

Based on the results in the current investigation, principals should pay close attention to the impact 1:1 computing has on the achievement of students with disabilities as it had a negative influence on this subgroup in two of the four time clusters. School leaders should also recognize that 1:1 computing programs can have no impact (or a negative one) on student test scores, especially with low implementation fidelity.

Since implementation fidelity is such an important factor in the successful use of 1:1 computing to improve student achievement, it would be reasonable for Ohio policy makers to link financial incentives/grants for the deployment of 1:1 computing programs to the best practices cited above. This would include the development of a comprehensive plan, professional development prior to and throughout deployment of any devices to students, and ongoing monitoring of adult implementation and student impact measures.

One-to-one computing programs have the potential to improve student achievement and have, in fact, successfully attained this goal in many schools. However, 
there are also several 1:1 programs that have fallen short of this expected outcome. Providing students and teachers with $24 / 7$ access to a mobile computing device is only the first step toward using technology as an effective learning tool (Weston \& Bain, 2010). Similar to other educational reforms, the intended purpose of a 1:1 computing program, as well as the fidelity of implementation, will ultimately determine the effect of such a program on learning. If mobile devices become $\$ 1000$ pencils because schools are in a "spray and pray" mode - where school leaders "spray" technology into classrooms (without a well-articulated plan and clear goals) and then "pray" they get an increase in learning (without changing the culture of teaching and learning) - then schools will not realize a positive return on their investment as measured by an increase in student achievement (November, 2014). 


\section{References}

Adelman, N., Donnelly, M. B., Dove, T., Tiffany-Morales, J., Wayne, A., \& Zucker, A. A. (2002). The integrated studies of educational technology: Professional development and teachers' use of technology. Menlo Park, CA: SRI International. Amirian, S. (2004). Putting tablet PCs to the test. THE Journal, 32(4), 28.

Apple. (2013). iPad design. Retrieved from http://www.apple.com/ipad/design/

Appleton, J. A., Christenson, S. L., \& Furlong, M. J. (2008). Student engagement with school: Critical conceptual and methodological issues of the construct.

Psychology in the Schools, 45 (5), 369-386.

Bahrampour, T. (2006, December 9). For some, laptops don't compute. The Washington Post. Retrieved from http://www.washingtonpost.com/wpdyn/content/article/2006/12/08/AR2006120801826.html

Bebell, D., \& Kay, R. (2010). One to one computing: A summary of the quantitative results from the Berkshire wireless learning initiative. Journal of Technology, Learning and Assessment, 9(2), 1-59.

Becker, H. J., Ravitz, J. L., \& Wong, Y. (1999). Teacher and teacher-directed student use of computers and software (Report No. 3). Teaching, Learning and Computing: 1998 National Survey. University of California, Irvine, CA: Center for Research on Information Technology and Organizations.

Berry, A. M., \& Wintle, S. E. (2009). Using laptops to facilitate middle school science learning: The results of hard fun (Research Brief). Maine Educational Policy Research Institute. Retrieved from http://usm.maine.edu/cepare/pdf/Bristol_Final_Copy_Cover.pdf 
Bhave, M. P. (2002). Classrooms with wi-fi. THE Journal, 30(4), 17.

Blankstein, A. M. (2010). Failure is not an option. Thousand Oaks, CA: Corwin.

Borenstein, M., Hedges, L.V., Higgins, J. P.T., \& Rothstein, H.R. (2009). Introduction to Meta-Analysis. West Sussex, UK: Wiley.

Bull, G. L., Bull, G. L, Garofolo, J., \& Harris, J. (2002). Grand challenges: Preparing for the technological tipping point. The International Society for Technology in Education (ISTE). Retrieved May 5, 2011 from http://www.iste.org/L\&L/29/8/featuredarticle/bull/index.htm

Burden, K., Hopkins, P., Male, T., Martin, S., \& Trala, C. (2012). iPad Scotland evaluation report. University of Hull, Hull, East Yorkshire, England: Technology Enhanced Learning Group.

Campbell, D., \& Ross, H. (1968). The Connecticut crackdown on speeding: Time-series data in quasi-experimental analysis. Law \& Society Review, 3(1), 33-54.

Campbell, D. T., \& Stanley, J. C. (1963). Experimental and quasi-experimental designs for research. Boston, MA: Houghton Mifflin Company.

Carini, R. M., Kuh, G. D., \& Klein, S. P. (2006). Student engagement and student learning: Testing the linkages. Research in Higher Education, 47(1), 1-32.

Center for Applied Special Technology. (1984). Electronic learning tools. Retrieved December 16, 2013 from http://www.cast.org/learningtools/index.html Collier-Meek, M., Fallon, L. M., Sanetti, L. M., \& Maggin, D. M. (2013). Focus on implementation: Assessing and promoting treatment fidelity. Teaching Exceptional Children, 45(5), 52-59. 
Corn, J. (2009). Evaluation report on the progress of the North Carolina 1:1 learning technology initiative - Year 2. (North Carolina State Board of Education Report). North Carolina State University, Raleigh, NC: Friday Institute for Educational Innovation.

Cuban, L. (2001). Oversold and underused: Computers in the classroom. Cambridge, MA: Harvard University Press.

Dawson, K., Cavanaugh, C., \& Ritzhaupt, A. (2008). Florida's EETT leveraging laptops initiative and its impact on teaching practices. Journal of Research on Technology in Education, 41(2), 143-159.

Dede, C., \& Richards, J. (Eds.). (2012). Digital teaching platforms: Customizing classroom learning for the student. New York, NY: Teachers College Press.

Dunleavy, M., \& Heinecke, W. F. (2007). The impact of 1:1 laptop use on middle school math and science standardized test scores. Computers in the Schools, 24(3), 7-22.

Enriquez, A. G. (2010). Enhancing student performance using tablet computers. College Teaching Technology, 58, 77-84.

eTECH Ohio. (2012). Biennial educational technology assessment: Statewide report. Retrieved from http://www.etech.ohio.gov/beta

Field, A. (2009). Discovering statistics using SPSS. Thousand Oaks, CA: Sage.

Finn, J. D., \& Rock, D. A. (1997). Academic success among students at-risk. Journal of Applied Psychology, 82, 221-234.

Furrer, C., \& Skinner, E. (2003). Sense of relatedness as a factor in children's academic engagement and performance. Journal of Educational Psychology, 95 (1), $148-162$. 
Garcia, E. R., \& Friedman, A. (2011, June). There's an app for that: A study using iPads in a United States History classroom. Paper presented at Wake Forest University, Winston-Salem, NC. Retrieved from http://www.wfu.edu/education/gradtea/forum2011/research.proceedings.2011.pdf

Goldberg, A., Russell, M., \& Cook, A. (2003). The effect of computers on student learning: A meta-analysis of studies from 1992 to 2002. Journal of Technology, Learning, and Assessment, 2(1), 55-70.

Google. (2013). Introducing chromebooks. Retrieved from http://www.google.com/intl/en/chrome/devices/features.html

Gottman, J. M., McFall, R. M., \& Barnett, J. T. (1969). Design and analysis of research using time series. Psychological Bulletin, 72(4), 299-306.

Gray, L., \& Lewis, L. (2009). Educational technology in U.S. public districts: Fall 2008 (NCES 2010- 003). Retrieved from U.S. Department of Education, National Center for Education Statistics website: http://nces.ed.gov/pubs2010/2010003.pdf

Gray, L., Thomas, N., \& Lewis, L. (2010). Educational technology in U.S. public schools: Fall 2008 (NCES 2010- 034). Retrieved from U.S. Department of Education, National Center for Education Statistics website: http://nces.ed.gov/pubs2010/2010034.pdf

Greaves, T. (2012). One-to-one computing. In C. Dede \& J. Richards (Eds.), Digital teaching platforms: Customizing classroom learning for the student (pp. 37-52). New York, NY: Teachers College Press. 
Greaves, T., Hayes, J., Wilson, L., Gelniak, M., \& Peterson, R. (2010). The technology factor: Nine keys to student achievement and cost effectiveness. Shelton, CT: MDR.

Gulek, J. C., \& Demirtas, H. (2005). Learning with technology: The impact of laptop use on student achievement. Journal of Technology, Learning, and Assessment, 3(2), $1-38$.

Guskey, T. R. (2009). Practical solutions to serious problems in standards-based grading. Thousand Oaks, CA: Corwin.

Harn, B., Parisi, D., \& Stoolmiller, M. (2013). Balancing fidelity with flexibility and fit: What do we really know about fidelity on implementation in schools? Exceptional Children, 79(2), 181-193.

Hegedus, S., \& Kaput, J. (2004, September). An introduction to the profound potential of connected algebra activities: Issues of representation, engagement and pedagogy. Paper presented at the 28th Conference of the International Group for the Psychology of Mathematics Education, Bergen, Norway. Retrieved from http://www.simcalc.umassd.edu/downloads/RR261_Kaput.pdf

Heinrich, P. (2012). The iPad as a tool for education: A study of the introduction of iPads at Longfield Academy, Kent, England. Retrieved from NAACE website: http://www.naace.co.uk/publications/longfieldipadresearch

Henderson, S., \& Yeow, J. (2012). iPad in Education - A case study of iPad adoption and use in a primary school. HICSS Proceedings of the $201245^{\text {th }}$ Hawaii International Conference on System Sciences, 78-87. 
Holcomb, L. (2009). Results \& lessons learned from 1:1 laptop initiatives: A collective review. Tech Trends: Linking Research \& Practice to Improve Learning, 53(6), 49-55.

Hu, W. (2007, May 4). Seeing no progress, some schools drop laptops. The New York Times. Retrieved from http://www.nytimes.com/ 2007/05/04/education/04laptop.html?_r=2\&oref=slogin\&ref=nyre\&

Huntley, L., \& Greever-Rice, T. (2007). Analysis of 2005 MPA results for eMINTS students. Retrieved November 9, 2011 from eMINTS National Center, from http://www.emints.org/evaluation/reports/map2005.pdf

Intel Inc. (2008). Technology as a tool for system-wide transformation: The 21st century learning initiative at Auburn City Schools. Retrieved from http://www.k12blueprint.com/sites/default/files/Intel_Edu_Auburn_3_WP_HiRes .pdf

Johnson, D. H., \& Johnson, R. T. (1998). Learning together and alone: Cooperative, competitive and individualistic learning. New York, NY: Pearson.

Khan, S. (2006). Khan academy. Retrieved December 16, 2013 from http://www.khanacademy.org/

Klem, A. M., \& Connell, J. P. (2004). Relationships matter: Linking teacher support to student engagement and achievement. Journal of School Health, 74 (7), 262-273.

Larmer, J. (2009). Project based learning starter kit. Novato, CA: Buck Institute for Education.

Lee, V. E., \& Smith, J. B. (1993). Effects of school restructuring on the achievement and engagement of middle-grade students. Sociology of Education, 66, 164-187. 
Lee, V. E., \& Smith, J. B. (1995). Effects of high school restructuring on gains in achievement and engagement for early secondary school students. Sociology of Education, 68, 241-270.

Lei, J. (2010a). Quantity versus quality: A new approach to examine the relationship between technology use and student outcomes. The British Journal of Educational Technology, 41(3), 455-472. Doi10.1111/j.1467-8535.2009.00961.x

Lei, J. (2010b). Conditions for ubiquitous computing: What can be learned from a longitudinal study. Computers in Schools, 27, 35-53.

Lei, J., \& Zhao, Y. (2008). One-to-one computing: What does it bring to schools? Journal of Educational Computing Research, 39(2), 97-122.

Lemke, C., \& Martin, C. (2003). One-to-one computing in Maine: A state profile. Retrieved June 14, 2008 from http://www.metiri.com/NSFStudy/MEProfile.pdf Li, Q., \& Ma, X. (2010). A meta-analysis of the effects of computer technology on school students' mathematics learning. Education Psychology Review, 22, 215 243.

Li, S. C., \& Pow, W. C. (2011). Affordance of deep infusion of one-to-one tablet PCs into and beyond the classroom. International Journal of Instructional Media, 38(4), 319-326.

Lowther, D., Ross, S., \& Morrison, G. (2003). When each one has one: The influences on teaching strategies and student achievement of using laptops in the classroom. Educational Technology Research and Development, 51(2), 23-44. 
Lowther, D., Strahl, D., Inan, F., \& Bates, J. (2007). Freedom to learn program Michigan 2005-06 evaluation report. Memphis, TN: Center for Research in Education Policy. Retrieved from http://www.memphis.edu/crep/pdfs/Michigan_Freedom_yo_Learn_Laptop_ Program.pdf

Lowther, D. L., Strahl, J. D., Zoblotsky, T. A., \& Huang,Y.(2008). Florida's enhancing education through technology (FL EETT) leveraging laptops: Effective models for enhancing student achievement. 2007-2008 Evaluation report: Classroom practices. Center for Research in Educational Policy, University of Memphis. Retrieved from http://etc.usf.edu/laptops4learning/reports/FL_EETT_Yr2_Final_Report.pdf

Management Council of the Ohio Education Computer Network. (1994). INFOhio electronic resources. Retrieved December 16, 2013 from http://www.infohio.org

Mann, D. (2008). Documenting outcomes for Henrico County public schools laptop computing initiative. Retrieved from http://jcots.state.va.us/2008Content/Materials/OpenEd/ Henrico_Laptop_Report.pdf

Manninger, R. M., \& Holden, M. E. (2009). Put the textbooks away: Preparation and support for a middle school one-to-one laptop initiative. American Secondary Education, 38(1), 1-33.

Marks, H. M. (2000). Student engagement in instructional activity: Patterns in the elementary, middle, and high school years. American Educational Research Journal, 37, 153-184. 
Marx, R. W., Blumenfeld, P., Krajcik, J., Fishman, B., Soloway, E., Geier, R., \& Tal, T. (2000). Inquiry-based science in the middle grades: Assessment of student learning in the context of systematic reform. University of Michigan, Ann Arbor, MI: Center for Learning Technologies in Urban Schools.

Marzano, R., Pickering, D., \& Pollock, J. (2001). Classroom instruction that works: Research-based strategies for increasing student achievement. Alexandria, VA: Association for Supervision and Curriculum Development.

McLester, S. (2011). Lessons learned from one-to-one. District Administrator, June, 3438. Retrieved July 28, 2013 from http://www.districtadministration.com/toc/1513 Metiri Group. (2006). Technology in schools: What the research says. Retrieved June 8, 2008 from http://www.cisco.com/web/strategy/docs/education/ TechnologyinSchoolsReport.pdf

Meyers, C., \& Brandt, W.C. (2010). A summary of the external findings for the eMINTS (enhancing Missouri's instructional networked teaching strategies) program from 1999-2009. Retrieved from http://www.emints.org/wpcontent/uploads/2011/07/summary_emints_research.pdf

Mitchell Institute. (2004). One-to-one laptops in a high school environment. Piscataquis Community High School study. (Final Report). Retrieved from http://www.projectred.org/uploads/Piscataquis_one_to_one_Laptops_Report.pdf Mitchell, M. (1993). Situational interest: Its multifaceted structure in the secondary school mathematics classroom. Journal of Educational Psychology, 85(3), 424436. 
Mouza, C. (2008). Learning with laptops: Implementation and outcomes in an urban, under- privileged school. Journal of Research on Technology in Education, 40(4), 447-472.

Muir, M., Knezek, G., \& Christensen, R. (2004). The Maine learning technology initiative. Learning and Leading with Technology, 32(3), 6-11.

Murray, O. T., \& Olcese, N. R. (2011). Teaching and learning with iPads, ready or not? Tech Trends, 55(6), 42-48.

National Center for Educational Statistics. (2010). Number and internet access of instructional computers and rooms in public schools (Table 108). Retrieved from http://nces.ed.gov/programs/digest/d10/tables/dt10_108.asp

National Science Digital Library. (n.d.) Retrieved December 17, 2013 from http://nsdl.org

Nedungadi, P., \& Raman, R. (2012). A new approach to personalization: Integrating elearning and m-learning. Educational Technology \& Research Development, 60, 659-678.

Netgear. (2013). Best practices for enabling BYOD in education. Retrieved from http://www.netgear.com/images/Netgear-whitepaper-BYOD_070113_tcm1877080.pdf

November, A. (2013). Why schools must move beyond one-to-one computing. Retrieved August 1, 2013 from http://novemberlearning.com/educational-resources-foreducators/teaching-and-learning-articles/why-schools-must-move-beyond-one-toone-computing/ 
Ohio Department of Education. (1998). District and building report card data. Retrieved December 16, 2013 from http://webapp2.ode.state.oh.us/reportcard/archives/Default.asp

Ohio Department of Education. (2004a). Blueprints for Ohio graduation tests. Retrieved December 16, 2013 from http://education.ohio.gov/Topics/Testing/OhioAchievement-Assessments/Blueprints-for-Ohio-Graduation-Tests

Ohio Department of Education. (2004b). Ohio graduation test assessment results. Retrieved December 16, 2013 from http://education.ohio.gov/Topics/Testing/Testing-Results/Ohio-Graduation-TestsOGT-Assessment-Results

Ohio Department of Education. (2004c). Statistical summaries - Ohio graduation test. Retrieved December 16, 2013 from http://education.ohio.gov/Topics/Testing/Statistical-Summaries-and-ItemAnalysis-Reports

Ohio Department of Education. (2005). Report card historical information. Retrieved December 17, 2013 from http://education.ohio.gov/getattachment/Topics/Data/Report-Card/Ohio-ReportCards/Local-Report-Card-and-Accountability-Information/2005-2006explanation-of-report-card-calc.pdf.aspx

Ohio Department of Education. (2011). Model curriculum for English language arts, mathematics, science and social studies. Retrieved December 16, 2013 from http://education.ohio.gov/Topics/Academic-Content-Standards/English 
Okolo, C. M., \& Diedrich, J. (2014). Twenty-five years later: How is technology used in the education of students with disabilities? Journal of Special Education Technology, 29(1), 1-20.

Ozok, A. A., Benson, D., Chakraborty, J., \& Norcio, A. F. (2008). A comparative study between tablet and laptop PCs: User satisfaction and preferences. International Journal of Human-Computer Interaction, 24(3), 329-352.

Partnership for $21^{\text {st }}$ Century Skills. (n.d.) Framework for $21^{\text {st }}$ century learning. Retrieved November 17, 2011 from http://p21.org/overview/skills-framework

Penuel, W. R. (2006). Implementation and effects of one-to-one computing initiatives: A research synthesis. Journal of Research on Technology in Education, 38(3), 329348.

Phatak, O. (2102). Netbook vs. notebook vs. laptop. Retrieved from http://www.buzzle.com/articles/netbook-vs-notebook-vs-laptop.html

Pintrich, P. R., \& DeGroot, E. V. (1990). Motivational and self-regulated learning components of classroom academic performance. Journal of Educational Psychology, 82(1), 33-44.

Project Tomorrow, Speak Up National Research Project. (2013). From chalkboards to tablets: The emergence of the K-12 digital learner. Retrieved from http://www.tomorrow.org/speakup/pdfs/SU12-Students.pdf

Protheroe, N. (2005). Technology and student achievement. Principal, 85(2), 46-48. Puentedura, R. (2009). As we may teach: Educational technology, from theory to practice. New York, NY: Routledge. 
Reeve, J. (2006). Extrinsic rewards and inner motivation. In C. Evertson, C. M. Weinstein, \& C. S. Weinstein (Eds.), Handbook of classroom management: Research, practice, and contemporary issues (pp. 645-664). Mahwah, NJ: Erlbaum.

Richardson, J. W., McLeod, S., Flora, K., Sauers, N. J., Kannan, S., \& Sincar, M. (2013). Large scale 1:1 computing initiatives: An open access database. International Journal of Education and Development using Information and Communication Technology, 9(1), 4-18.

Riley, R. D., Lambert, P. C., \& Abo-Zaid, G. (2010). Meta-analysis of individual participant data: rationale, conduct, and reporting. British Medical Journal, 340(7745), 521-525. doi: 10.1136/bmj.c221

Rockman, S. (1998). Powerful tools for schooling: Second year study of the laptop program. Anytime Anywhere Learning Project. Retrieved from http://www.microsoft.com/education/downloads/aal/research2.rtf

Rockman, S. (2000). A more complex picture: Laptop use and impact in the context of changing home and school access. Retrieved from http://rockman.com/projects/laptop

Rockman, S. (2003). Learning from laptops. Threshold Magazine, 1(1), 24-28.

Rockman, S. (2004). A study in learning. Technology \& Learning, 25(3), 34-37.

Rouse, M. (2010). Tablet pc definition. Retrieved from http://searchmobilecomputing.techtarget.com/definition/tablet-PC 
Russell, M., Bebell, D., \& Higgins, J. (2004). Laptop learning: A comparison of teaching and learning in upper elementary classrooms equipped with shared carts of laptops and permanent 1:1 laptops. Journal of Educational Computing Research, 30(4), 313-330.

Sauers, N. J., \& McLeod, S. (2012). What does the research say about school one-to-one computing initiatives? (Policy Brief). University of Kentucky, Lexington, KY: UCEA Center for Advanced Study of Technology Leadership in Education.

Shadish, W. R., Cook, T. D., \& Campbell, D. T. (2002). Experimental and quasiexperimental designs for generalized causal inference. Boston, MA: Houghton Mifflin.

Shernoff, D. J., Csikszentmihalyi, M., Schneider, B., \& Shernoff, E. (2003). Student engagement in high school classrooms from the perspective of flow theory. School Psychology Quarterly, 18(2), 158-176.

Shapley, K. S., Sheehan, D., Maloney, C., \& Caranikas-Walker, F. (2010). Evaluating the implementation fidelity of technology immersion and its relationship with student achievement. Journal of Technology, Learning, and Assessment, 9(4), 1-67.

Silvernail, D. (2008). Maine's impact study of technology in mathematics (MISTM). Paper presented at the 2008 Annual Meeting of the American Educational Research Association, New York, NY. 
Silvernail, D. L., \& Buffington, P. J. (2009). Improving mathematics performance using laptop technology: The importance of professional development for success. (Policy Brief). Maine Education Policy Institute. Retrieved August 1, 2013 from http://www2.usm.maine.edu/mepri/sites/default/files/Mathematics_Final_cover.p df

Silvernail, D. L., \& Gritter, A. K. (2007). Maine's middle school laptop program: Creating better writers. Maine Education Policy Institute. Retrieved November 12,2011 from http://www.usm.maine.edu/cepare/Impact_on_Student_Writing_Brief.pdf

Silvernail, D. L., \& Lane, D. M. (2004). The impact of Maine's one-to-one laptop program on middle school teachers and students. Retrieved June 28, 2008 from http://www.usm.maine.edu/cepare/mlti.htm

Skinner, E. A., \& Belmont, M. J. (1993). Motivation in the classroom: Reciprocal effects of teacher behavior and student engagement across the school year. Journal of Educational Psychology, 85(4), 571-581.

Skinner, E. A., Wellborn, J. G., \& Connell, J. P. (1990). What it takes to do well in school and whether I've got it: The role of perceived control in children's engagement and school achievement. Journal of Educational Psychology, 82, 2232.

Slavin, R. E. (1989). School and classroom organization. Hillsdale, NJ: Erlbaum. 
Sonnenberg, M., \& Bartelli, B. (2013, June). iPad immersion: A middle school study.

Paper presented at the International Society for Technology in Education (ISTE) Annual Conference, San Antonio, Texas. Retrieved from https://www.isteconference.org/uploads/ISTE2013/HANDOUTS/KEY_80666631 /ISTE2013ResearchPaperSonnenberg_RP.BartelliFINALDRAFT.pdf

Soloway, E., Norris, C., Blumenfeld, P., Fishman, B., Krajcik, J., \& Marx, R. (2001). Handheld devices are ready-at-hand. Communications of the ACM, 44(6), 15-20.

Stewart, L., Rydzewska, L., \& Vale, C. (2010). Individual participant data (IPD) reviews and meta-analyses. Paper presented at the $18^{\text {th }}$ Cochrane Colloquium, Keystone, USA. Retrieved from http://ipdmamg.cochrane.org/sites/ipdmamg.cochrane.org/ files/uploads/IPD\%20workshop\%20slides\%202010.pdf

Tabachnick, B., \& Fidell, L. (2013). Using multivariate statistics. Boston, MA: Pearson. Technology Counts. (2003). Access to technology data tables. Education Week, 22(35), $54-61$.

Tech Target. (2013). Definition of tablet pc. Retrieved from http://searchmobilecomputing.techtarget.com/definition/tablet-PC

Trimmel, M., \& Bachmann, J. (2004). Cognitive, social, motivational and health aspects of students in laptop classrooms. Journal of Computer Assisted Learning, 20(2), $151-158$.

Trochim, W. M., \& Donnelly, J. P. (2008). Research methods knowledge base. Mason, $\mathrm{OH}$ : Centgage Learning. 
Twining, P., \& Evans, D. (2005). Should there be a future for tablet PCs in schools? Journal of Interactive Media in Education, 20, 1-18.

Tyack, D., \& Tobin, W. (1994). The "grammar" of schooling: Why has it been so hard to change? American Educational Research Journal, 31(3), 453-479.

Webopedia. (2013). Laptop computer. Retrieved from http://www.webopedia.com/TERM/L/laptop_computer.html

Weston, M. E., \& Bain, A. (2010). The end of techno-critique: The naked truth about 1:1 laptop initiatives and change. The Journal of Technology, Learning, and Assessment, 9(6), 1-25.

$\mathrm{Xu}, \mathrm{Y} .(2010)$. Examining the effects of digital feedback on student engagement and achievement. Journal of Educational Computing Research, 43(2), 275-291.

Yazzie-Mintz, E., \& McCormick, K. (n.d). Finding the humanity in the data: Understanding, measuring and strengthening student engagement. In S. Christenson, A. Reschly, \& C. Wylie (Eds.), Handbook of research on student achievement (pp. 743-761). Springer Science \& Business Media.

Zucker, A. (2004). Developing a research agenda for ubiquitous computing in schools. Journal of Educational Computing Research, 30(4), 371-386. 
APPENDIX A 
Table A1

Demographic Information for Study Participant Schools

\begin{tabular}{|c|c|c|c|c|c|c|c|c|}
\hline \multirow[b]{2}{*}{ Pair } & \multicolumn{4}{|c|}{ Treatment Schools } & \multicolumn{4}{|c|}{ Control Schools } \\
\hline & $\mathrm{n}$ & White & ED & SWD & $\mathrm{n}$ & White & ED & SWD \\
\hline 1 & 104 & $80.6 \%$ & $22.3 \%$ & $9.7 \%$ & 84 & $90.4 \%$ & $19.7 \%$ & $10.5 \%$ \\
\hline 2 & 183 & $84.2 \%$ & $44.3 \%$ & $17.4 \%$ & 139 & $89.1 \%$ & $39.0 \%$ & $11.8 \%$ \\
\hline 3 & 47 & $97.5 \%$ & $29.3 \%$ & $14.4 \%$ & 39 & $98.3 \%$ & $27.0 \%$ & $10.4 \%$ \\
\hline 4 & 77 & $97.3 \%$ & $12.1 \%$ & $12.8 \%$ & 77 & $95.6 \%$ & $22.4 \%$ & $10.7 \%$ \\
\hline 5 & 132 & $97.8 \%$ & $37.7 \%$ & $14.3 \%$ & 172 & $98.1 \%$ & $41.7 \%$ & $16.4 \%$ \\
\hline 6 & 53 & $99.7 \%$ & $10.1 \%$ & $9.5 \%$ & 44 & $99.2 \%$ & $9.5 \%$ & $9.8 \%$ \\
\hline 7 & 171 & $97.5 \%$ & $32.9 \%$ & $10.6 \%$ & 159 & $96.3 \%$ & $34.4 \%$ & $13.1 \%$ \\
\hline 8 & 133 & $96.9 \%$ & $45.0 \%$ & $14.1 \%$ & 147 & $97.1 \%$ & $49.5 \%$ & $21.0 \%$ \\
\hline 9 & 166 & $98.0 \%$ & $30.3 \%$ & $14.3 \%$ & 176 & $95.9 \%$ & $27.3 \%$ & $17.9 \%$ \\
\hline 10 & 137 & $97.9 \%$ & $31.0 \%$ & $17.7 \%$ & 142 & $96.8 \%$ & $34.5 \%$ & $16.8 \%$ \\
\hline 11 & 81 & $93.9 \%$ & $22.6 \%$ & $8.1 \%$ & 153 & $93.7 \%$ & $17.9 \%$ & $10.9 \%$ \\
\hline 12 & 59 & $86.7 \%$ & $17.4 \%$ & $0.0 \%$ & 63 & $81.2 \%$ & - & $0.0 \%$ \\
\hline 13 & 77 & $92.9 \%$ & $30.6 \%$ & $16.4 \%$ & 62 & $98.0 \%$ & $28.8 \%$ & $10.9 \%$ \\
\hline 14 & 79 & $98.2 \%$ & $48.9 \%$ & $19.1 \%$ & 94 & $98.9 \%$ & $51.9 \%$ & $16.8 \%$ \\
\hline 15 & 194 & $71.9 \%$ & $39.7 \%$ & $19.3 \%$ & 209 & $88.1 \%$ & $34.7 \%$ & $13.8 \%$ \\
\hline 16 & 99 & $97.9 \%$ & $37.3 \%$ & $15.6 \%$ & 79 & $97.2 \%$ & $32.6 \%$ & $15.3 \%$ \\
\hline 17 & 202 & $77.5 \%$ & $5.3 \%$ & $0.0 \%$ & 154 & $80.1 \%$ & - & $0.0 \%$ \\
\hline 18 & 17 & $92.6 \%$ & $22.5 \%$ & $0.0 \%$ & 16 & $95.0 \%$ & - & $0.0 \%$ \\
\hline 19 & 43 & $89.9 \%$ & $18.8 \%$ & $9.5 \%$ & 46 & $83.3 \%$ & $22.4 \%$ & $7.5 \%$ \\
\hline 20 & 67 & $88.5 \%$ & $19.3 \%$ & $9.1 \%$ & 70 & $93.2 \%$ & $21.5 \%$ & $9.6 \%$ \\
\hline 21 & 191 & $95.4 \%$ & $28.7 \%$ & $15.5 \%$ & 168 & $97.8 \%$ & $33.0 \%$ & $14.7 \%$ \\
\hline 22 & 74 & $91.8 \%$ & $31.0 \%$ & $20.9 \%$ & 76 & $95.9 \%$ & $26.8 \%$ & $12.8 \%$ \\
\hline 23 & 187 & $88.8 \%$ & $19.7 \%$ & $14.8 \%$ & 172 & $89.9 \%$ & $21.1 \%$ & $11.6 \%$ \\
\hline 24 & 139 & $78.9 \%$ & - & $0.0 \%$ & 107 & $78.7 \%$ & - & $0.0 \%$ \\
\hline
\end{tabular}

Note. All values are mean values for the 5 to 8 years that each school was part of the study.

$n=$ Enrollment for 10th grade; ED = Economically Disadvantaged and SWD = Students with Disabilities 
Table A2

Background Information for Study Schools

\begin{tabular}{|c|c|c|c|c|c|}
\hline \multirow[b]{2}{*}{ Pair } & \multirow[b]{2}{*}{ Time } & \multirow[b]{2}{*}{ Type } & \multicolumn{2}{|c|}{ Treatment Schools } & \multirow{2}{*}{$\begin{array}{l}\text { Control } \\
\text { Schools } \\
\text { Rating }\end{array}$} \\
\hline & & & Rating & Device & \\
\hline 1 & 1 & Public & Excellent & iPad & Excellent \\
\hline 2 & 1 & Public & Excellent & Laptop & Excellent \\
\hline 3 & 1 & Public & Excellent & iPad & Effective \\
\hline 4 & 1 & Public & Excellent & Netbook & Excellent \\
\hline 5 & 1 & Public & Excellent & Netbook & Excellent \\
\hline 6 & 1 & Public & Excellent & iPad & Excellent \\
\hline 7 & 1 & Public & Excellent & Netbook & Excellent \\
\hline 8 & 1 & Public & Effective & iPad & Effective \\
\hline 9 & 1 & Public & Excellent & Chromebook & Excellent \\
\hline 10 & 1 & Public & Excellent & iPad & Excellent \\
\hline 11 & 1 & Public & Excellent & Netbook & Excellent \\
\hline 12 & 1 & Parochial & Excellent & iPad & Excellent \\
\hline 13 & 2 & Public & Excellent & Netbook & Excellent \\
\hline 14 & 2 & Public & Effective & Netbook & Effective \\
\hline 15 & 2 & Public & Excellent & iPad & Excellent \\
\hline 16 & 2 & Public & Effective & Laptop & Effective \\
\hline 17 & 2 & Parochial & Excellent & iPad & Excellent \\
\hline 18 & 2 & Parochial & Excellent & Laptop & Excellent \\
\hline 19 & 2 & Public & Excellent & Laptop & Excellent \\
\hline 20 & 3 & Public & Excellent & Laptop & Effective \\
\hline 21 & 3 & Public & Effective & Laptop & Effective \\
\hline 22 & 4 & Public & Excellent & Laptop & Excellent \\
\hline 23 & 4 & Public & Excellent & Laptop & Excellent \\
\hline 24 & 4 & Parochial & Excellent & Laptop & Excellent \\
\hline
\end{tabular}

Note. Rating is based on the school report card for the year prior to implementing a 1:1 program for treatment schools and the same year for it paired control school. Parochial school ratings are based on a calculated PI. 
APPENDIX B 
Table B1

Descriptive Statistics for Performance Index by Pairs

\begin{tabular}{|c|c|c|c|c|c|c|}
\hline Pair & Group & $n$ & $M$ & $S D$ & Skewness & Kurtosis \\
\hline \multirow[t]{2}{*}{1} & Control & 5 & 106.48 & 2.68 & -0.156 & -2.244 \\
\hline & Treatment & 5 & 105.08 & 2.13 & -0.645 & 0.691 \\
\hline \multirow[t]{2}{*}{2} & Control & 5 & 101.60 & 1.85 & 0.607 & -0.243 \\
\hline & Treatment & 5 & 98.84 & 2.95 & -1.778 & 3.184 \\
\hline \multirow[t]{2}{*}{3} & Control & 5 & 93.80 & 2.14 & -0.377 & -1.974 \\
\hline & Treatment & 5 & 99.18 & 4.04 & -0.561 & -3.116 \\
\hline \multirow[t]{2}{*}{4} & Control & 5 & 103.70 & 1.32 & -0.113 & -2.439 \\
\hline & Treatment & 5 & 107.18 & 1.13 & -0.344 & -0.625 \\
\hline \multirow[t]{2}{*}{5} & Control & 5 & 99.16 & 2.97 & -0.489 & -3.117 \\
\hline & Treatment & 5 & 104.06 & 2.03 & -0.071 & 0.052 \\
\hline \multirow[t]{2}{*}{6} & Control & 5 & 105.74 & 2.16 & 0.511 & -1.552 \\
\hline & Treatment & 5 & 106.70 & 1.37 & -0.443 & -1.178 \\
\hline \multirow[t]{2}{*}{7} & Control & 5 & 101.20 & 1.31 & -1.084 & 2.489 \\
\hline & Treatment & 5 & 102.08 & 2.99 & -0.067 & -2.909 \\
\hline \multirow[t]{2}{*}{8} & Control & 5 & 96.82 & 3.08 & 1.151 & 1.246 \\
\hline & Treatment & 5 & 96.26 & 2.71 & 0.223 & -1.934 \\
\hline \multirow[t]{2}{*}{9} & Control & 5 & 101.30 & 1.77 & -0.784 & -0.259 \\
\hline & Treatment & 5 & 99.62 & 1.45 & 0.526 & -0.013 \\
\hline \multirow[t]{2}{*}{10} & Control & 5 & 100.12 & 2.82 & 1.295 & 1.960 \\
\hline & Treatment & 5 & 97.94 & 2.75 & -0.242 & -2.580 \\
\hline \multirow[t]{2}{*}{11} & Control & 5 & 104.74 & 1.94 & -0.056 & -2.319 \\
\hline & Treatment & 5 & 105.46 & 3.85 & -0.791 & -1.805 \\
\hline \multirow[t]{2}{*}{12} & Control & 5 & 108.16 & 3.59 & 0.037 & -2.874 \\
\hline & Treatment & 5 & 110.62 & 3.63 & 1.045 & 0.995 \\
\hline \multirow[t]{2}{*}{13} & Control & 6 & 106.48 & 2.86 & 0.222 & -1.136 \\
\hline & Treatment & 6 & 103.72 & 2.18 & -0.189 & -1.906 \\
\hline
\end{tabular}




\begin{tabular}{|c|c|c|c|c|c|c|}
\hline \multirow[t]{2}{*}{14} & Control & 6 & 94.25 & 2.79 & -0.671 & -1.038 \\
\hline & Treatment & 6 & 93.98 & 3.57 & 0.113 & -2.075 \\
\hline \multirow[t]{2}{*}{15} & Control & 6 & 98.23 & 2.21 & 0.371 & -2.492 \\
\hline & Treatment & 6 & 100.82 & 2.08 & -0.568 & -0.517 \\
\hline \multirow[t]{2}{*}{16} & Control & 6 & 97.47 & 4.67 & 1.723 & 3.250 \\
\hline & Treatment & 6 & 96.63 & 2.99 & -0.894 & 0.210 \\
\hline \multirow[t]{2}{*}{17} & Control & 6 & 108.07 & 0.95 & 1.422 & 2.152 \\
\hline & Treatment & 6 & 108.88 & 1.93 & -0.383 & -1.280 \\
\hline \multirow[t]{2}{*}{18} & Control & 6 & 111.05 & 3.41 & 0.464 & -0.458 \\
\hline & Treatment & 6 & 101.73 & 2.57 & 1.598 & 2.571 \\
\hline \multirow[t]{2}{*}{19} & Control & 6 & 105.25 & 1.97 & -0.156 & -1.321 \\
\hline & Treatment & 6 & 106.20 & 3.60 & -0.033 & -3.166 \\
\hline \multirow[t]{2}{*}{20} & Control & 7 & 100.50 & 2.77 & 0.540 & 0.549 \\
\hline & Treatment & 7 & 105.23 & 1.94 & -0.972 & -0.131 \\
\hline \multirow[t]{2}{*}{21} & Control & 7 & 99.46 & 1.87 & 0.596 & 0.323 \\
\hline & Treatment & 7 & 98.86 & 1.07 & 0.356 & -1.681 \\
\hline \multirow[t]{2}{*}{22} & Control & 8 & 102.34 & 2.83 & 0.268 & -0.088 \\
\hline & Treatment & 8 & 101.09 & 2.60 & 0.090 & -0.857 \\
\hline \multirow[t]{2}{*}{23} & Control & 8 & 102.43 & 1.73 & 0.514 & -0.109 \\
\hline & Treatment & 8 & 103.06 & 1.76 & -0.228 & -1.212 \\
\hline \multirow[t]{2}{*}{24} & Control & 8 & 109.84 & 0.94 & 0.197 & 0.701 \\
\hline & Treatment & 8 & 108.59 & 1.19 & 0.154 & 0.086 \\
\hline
\end{tabular}


APPENDIX C 
Table C1

Descriptive Statistics for Math Scaled Scores by Implementation Time Cluster

\begin{tabular}{clccrrr}
\hline Time & Group & $n$ & $M$ & $S D$ & Skewness & Kurtosis \\
\hline \multirow{2}{*}{1} & Control & 60 & 438.87 & 6.49 & 0.234 & -0.212 \\
& Treatment & 60 & 439.00 & 9.31 & -0.112 & -0.613 \\
2 & Control & 42 & 439.54 & 12.19 & 0.318 & -0.576 \\
& Treatment & 42 & 436.65 & 9.58 & 0.004 & -0.900 \\
\multirow{2}{*}{3} & Control & 14 & 441.50 & 9.12 & 0.119 & -1.756 \\
& Treatment & 14 & 436.89 & 5.95 & 0.002 & -0.716 \\
\multirow{2}{*}{4} & Control & 24 & 437.73 & 7.27 & 0.262 & 0.376 \\
& Treatment & 24 & 440.10 & 5.86 & 0.109 & -1.205 \\
\hline
\end{tabular}

Table C2

Descriptive Statistics for Reading Scaled Scores by Implementation Time Cluster

\begin{tabular}{clcccrr}
\hline Time & Group & $n$ & $M$ & $S D$ & Skewness & Kurtosis \\
\hline 1 & Control & 60 & 428.67 & 5.94 & 0.429 & -0.009 \\
& Treatment & 60 & 428.99 & 6.42 & -0.180 & -0.591 \\
2 & Control & 42 & 431.97 & 7.52 & 0.041 & -0.579 \\
& Treatment & 42 & 429.70 & 5.70 & 0.180 & -0.114 \\
3 & Control & 14 & 427.34 & 4.36 & -0.093 & -1.555 \\
& Treatment & 14 & 427.61 & 3.97 & -0.224 & 0.164 \\
\multirow{2}{*}{4} & Control & 24 & 434.45 & 8.38 & 0.516 & -0.957 \\
& Treatment & 24 & 433.64 & 6.30 & -0.033 & -0.968 \\
\hline
\end{tabular}


Table C3

Descriptive Statistics for Science Scaled Scores by Implementation Time Cluster

\begin{tabular}{clccrrr}
\hline Time & Group & $n$ & $M$ & $S D$ & Skewness & Kurtosis \\
\hline \multirow{2}{*}{1} & Control & 60 & 426.29 & 7.01 & 0.567 & 0.098 \\
& Treatment & 60 & 426.48 & 8.01 & -0.155 & -0.714 \\
\multirow{2}{*}{2} & Control & 42 & 430.02 & 10.75 & 0.164 & -0.682 \\
& Treatment & 42 & 426.66 & 6.77 & -0.185 & -0.561 \\
\multirow{2}{*}{3} & Control & 14 & 426.40 & 6.48 & -0.550 & -0.735 \\
& Treatment & 14 & 427.14 & 4.67 & -0.044 & -1.184 \\
\multirow{2}{*}{4} & Control & 24 & 427.18 & 6.06 & -0.259 & -0.754 \\
& Treatment & 24 & 427.41 & 3.88 & -0.332 & -0.494 \\
\hline \multirow{2}{*}{} & & & & & &
\end{tabular}

Table C4

Descriptive Statistics for Social Studies Scaled Scores by Implementation Time Cluster

\begin{tabular}{clcccrr}
\hline Time & Group & $n$ & $M$ & $S D$ & Skewness & Kurtosis \\
\hline 1 & Control & 60 & 433.09 & 7.84 & 0.005 & 0.525 \\
& Treatment & 60 & 435.68 & 8.23 & 0.272 & 0.198 \\
2 & Control & 42 & 435.90 & 10.24 & -0.120 & -0.592 \\
& Treatment & 42 & 429.80 & 8.66 & 0.533 & -0.299 \\
3 & Control & 14 & 430.44 & 5.95 & 0.428 & -1.301 \\
& Treatment & 14 & 434.19 & 5.43 & 0.273 & -0.154 \\
4 & Control & 24 & 437.97 & 8.69 & 0.283 & 1.800 \\
& Treatment & 24 & 440.08 & 4.91 & -0.282 & 0.233 \\
\hline
\end{tabular}


Table C5

Descriptive Statistics for Writing Scaled Scores by Implementation Time Cluster

\begin{tabular}{clrrrrr}
\hline Time & Group & $n$ & $M$ & $S D$ & Skewness & Kurtosis \\
\hline \multirow{2}{*}{1} & Control & 60 & 426.73 & 7.14 & 0.641 & 0.197 \\
& Treatment & 60 & 428.82 & 7.84 & 0.424 & -0.184 \\
\multirow{2}{*}{2} & Control & 42 & 432.75 & 10.38 & 0.324 & -1.083 \\
& Treatment & 42 & 428.63 & 6.91 & -0.063 & 0.397 \\
3 & Control & 14 & 427.49 & 4.70 & 0.289 & -1.546 \\
& Treatment & 14 & 428.44 & 7.19 & -0.156 & -0.218 \\
4 & Control & 24 & 435.27 & 10.28 & 0.473 & -0.915 \\
& Treatment & 24 & 436.98 & 8.06 & -0.101 & -0.596
\end{tabular}


Table C6

Descriptive Statistics for Math Scaled Scores by Demographic Subgroup

\begin{tabular}{|c|c|c|c|c|c|c|}
\hline Variable & Group & $n$ & $M$ & $S D$ & Skewness & Kurtosis \\
\hline \multicolumn{7}{|l|}{ Gender } \\
\hline \multirow[t]{2}{*}{ Female } & Control & 129 & 437.27 & 8.45 & -0.009 & -0.358 \\
\hline & Treatment & 130 & 437.09 & 9.24 & 0.243 & -0.337 \\
\hline \multirow[t]{2}{*}{ Male } & Control & 127 & 438.85 & 9.09 & 0.343 & -0.086 \\
\hline & Treatment & 128 & 439.05 & 9.25 & -0.217 & -0.419 \\
\hline \multicolumn{7}{|l|}{ Race } \\
\hline \multirow[t]{2}{*}{ White } & Control & 140 & 440.13 & 9.45 & 0.418 & -0.008 \\
\hline & Treatment & 140 & 439.52 & 8.99 & -0.209 & -0.546 \\
\hline \multirow[t]{2}{*}{ Black } & Control & 15 & 423.74 & 11.77 & -1.334 & 2.514 \\
\hline & Treatment & 24 & 419.20 & 12.07 & -0.001 & -0.984 \\
\hline \multirow[t]{2}{*}{ Hispanic } & Control & 6 & 420.05 & 10.71 & 0.782 & -0.958 \\
\hline & Treatment & 12 & 423.19 & 6.70 & 0.339 & -0.205 \\
\hline \multirow[t]{2}{*}{ Other } & Control & 31 & 427.86 & 9.51 & 0.930 & 1.644 \\
\hline & Treatment & 32 & 432.52 & 10.70 & -0.370 & -0.140 \\
\hline \multicolumn{7}{|l|}{ Disability } \\
\hline \multirow[t]{2}{*}{ IEP } & Control & 69 & 399.06 & 7.60 & 0.077 & 0.289 \\
\hline & Treatment & 77 & 400.74 & 9.57 & 0.689 & 0.684 \\
\hline
\end{tabular}


Table C7

Descriptive Statistics for Reading Scaled Scores by Demographic Subgroup

\begin{tabular}{clccccc}
\hline Variable & Group & $n$ & $M$ & SD & Skewness & Kurtosis \\
Gender & & & & & & \\
Female & Control & 129 & 431.58 & 6.80 & 0.528 & -0.025 \\
& Treatment & 130 & 431.65 & 6.12 & 0.186 & -0.275 \\
Male & Control & 127 & 427.53 & 6.78 & 0.334 & -0.051 \\
& Treatment & 128 & 427.17 & 6.68 & -0.087 & -0.557 \\
Race & & & & & & \\
White & Control & 140 & 431.03 & 7.43 & 0.586 & -0.117 \\
& Treatment & 140 & 430.53 & 6.46 & 0.068 & -0.373 \\
Black & Control & 15 & 432.06 & 12.17 & -0.286 & -0.965 \\
& Treatment & 24 & 421.74 & 9.92 & -0.098 & -0.269 \\
Hispanic & Control & 4 & 418.60 & 7.72 & -1.812 & 3.477 \\
& Treatment & 12 & 420.72 & 6.51 & 1.035 & 1.593 \\
& Control & 31 & 424.00 & 8.05 & 0.067 & -0.646 \\
Other & Treatment & 31 & 429.01 & 9.62 & -0.561 & -0.031
\end{tabular}

Disability

\begin{tabular}{|c|c|c|c|c|c|c|}
\hline IEP & Control & 69 & 400.94 & 6.38 & -0.080 & -0.834 \\
\hline & Treatment & 76 & 400.98 & 7.33 & 0.222 & 1.013 \\
\hline
\end{tabular}


Table C8

Descriptive Statistics for Science Scaled Scores by Demographic

Subgroup

\begin{tabular}{clrrrrr}
\hline Variable & Group & $n$ & $M$ & $S D$ & Skewness & Kurtosis \\
\hline Gender & & & & & & \\
Female & Control & 129 & 424.42 & 7.97 & 0.40 & -0.051 \\
& Treatment & 130 & 424.07 & 6.89 & 0.029 & -0.340 \\
\multirow{2}{*}{ Male } & Control & 127 & 428.59 & 8.80 & 0.469 & 0.067 \\
& Treatment & 128 & 428.65 & 7.61 & -0.216 & -0.392
\end{tabular}

Race

\begin{tabular}{llccccc} 
White & Control & 140 & 428.31 & 8.56 & 0.488 & -0.024 \\
& Treatment & 140 & 427.96 & 7.13 & -0.295 & -0.265 \\
Black & Control & 15 & 416.82 & 12.05 & -0.747 & 0.994 \\
& Treatment & 24 & 408.28 & 9.62 & 0.013 & -0.841 \\
\multirow{2}{*}{ Hispanic } & Control & 5 & 403.90 & 8.35 & -0.312 & -0.838 \\
& Treatment & 12 & 413.96 & 8.91 & -0.164 & -1.618 \\
\multirow{2}{*}{ Other } & Control & 31 & 415.73 & 9.40 & 0.426 & 1.318 \\
& Treatment & 31 & 421.23 & 9.72 & -0.841 & 1.572
\end{tabular}

Disability

\begin{tabular}{|c|c|c|c|c|c|c|}
\hline \multirow[t]{2}{*}{ IEP } & Control & 68 & 392.53 & 7.04 & 0.284 & -0.080 \\
\hline & Treatment & 77 & 394.73 & 9.43 & 0.449 & 0.547 \\
\hline
\end{tabular}


Table C9

Descriptive Statistics for Social Studies Scaled Scores by Demographic Subgroup

\begin{tabular}{clccccc}
\hline Variable & Group & $n$ & $M$ & $S D$ & Skewness & Kurtosis \\
\hline Gender & & & & & & \\
Female & Control & 129 & 431.88 & 9.03 & 0.438 & 0.350 \\
& Treatment & 130 & 432.45 & 8.72 & 0.074 & 0.006 \\
\multirow{2}{*}{ Male } & Control & 127 & 435.68 & 9.73 & 0.095 & 0.297 \\
& Treatment & 128 & 436.08 & 9.19 & 0.105 & -0.092
\end{tabular}

Race

\begin{tabular}{llccccc} 
White & Control & 140 & 435.30 & 9.08 & 0.134 & -0.016 \\
& Treatment & 140 & 435.62 & 8.68 & -0.094 & -0.494 \\
\multirow{2}{*}{ Black } & Control & 15 & 426.70 & 1.88 & -0.460 & -0.516 \\
& Treatment & 24 & 422.14 & 11.48 & -0.182 & -0.591 \\
\multirow{2}{*}{ Hispanic } & Control & 4 & 416.32 & 7.11 & -0.933 & 0.408 \\
& Treatment & 12 & 419.53 & 9.78 & 2.020 & 5.149 \\
\multirow{2}{*}{ Other } & Control & 31 & 424.38 & 9.66 & -0.069 & -0.871 \\
& Treatment & 31 & 430.57 & 10.66 & -0.067 & -0.345
\end{tabular}

Disability

\begin{tabular}{|c|c|c|c|c|c|c|}
\hline \multirow[t]{2}{*}{ IEP } & Control & 69 & 396.60 & 8.58 & 0.362 & -0.124 \\
\hline & Treatment & 76 & 398.79 & 11.98 & -0.242 & 1.707 \\
\hline
\end{tabular}


Table C10

Descriptive Statistics for Writing Scaled Scores by Demographic Subgroup

\begin{tabular}{clccccc}
\hline Variable & Group & $n$ & $M$ & $S D$ & Skewness & Kurtosis \\
\hline Gender & & & & & & \\
Female & Control & 129 & 433.73 & 8.85 & 0.611 & -0.031 \\
& Treatment & 130 & 434.27 & 8.22 & 0.289 & -0.483 \\
Male & Control & 127 & 424.45 & 8.55 & 0.591 & 0.246 \\
& Treatment & 128 & 424.94 & 8.04 & 0.065 & -0.353 \\
Race & & & & & & \\
White & Control & 140 & 430.60 & 9.56 & 0.763 & -0.058 \\
& Treatment & 140 & 430.78 & 8.42 & 0.324 & -0.058 \\
Black & Control & 15 & 429.60 & 12.86 & -0.360 & -0.933 \\
& Treatment & 24 & 422.50 & 11.42 & 0.305 & -0.395 \\
Hispanic & Control & 5 & 413.48 & 10.08 & 0.227 & 1.782 \\
& Treatment & 12 & 423.05 & 8.16 & -0.130 & -1.659 \\
& Control & 31 & 422.20 & 6.69 & 0.062 & -1.195 \\
Other & Treatment & 31 & 430.10 & 8.51 & -0.154 & -0.631 \\
& & & & & & 0.259 \\
\hline Disability & Control & 68 & 400.97 & 6.83 & 0.259 & 0.116 \\
& Treatment & 77 & 403.32 & 9.03 & 0.469 & 0.289 \\
\hline & & & & & &
\end{tabular}


APPENDIX D 
Table D1

Frequency Data for Treatment Schools by Time Cluster

\begin{tabular}{|c|c|c|c|}
\hline Time & Variable & Frequency & Percentage \\
\hline \multirow[t]{7}{*}{1} & Type of School & & \\
\hline & Public & 11 & 91.7 \\
\hline & Parochial & 1 & 8.3 \\
\hline & Device & & \\
\hline & Laptop & 1 & 8.3 \\
\hline & Netbook & 5 & 41.7 \\
\hline & iPad & 6 & 50.0 \\
\hline \multirow[t]{7}{*}{2} & Type of School & & \\
\hline & Public & 5 & 71.4 \\
\hline & Parochial & 2 & 28.6 \\
\hline & Device & & \\
\hline & Laptop & 3 & 42.9 \\
\hline & Netbook & 2 & 28.6 \\
\hline & iPad & 2 & 28.6 \\
\hline \multirow[t]{7}{*}{3} & Type of School & & \\
\hline & Public & 2 & 100.0 \\
\hline & Parochial & 0 & 0.0 \\
\hline & Device & & \\
\hline & Laptop & 2 & 100.0 \\
\hline & Netbook & 0 & 0.0 \\
\hline & iPad & 0 & 0.0 \\
\hline \multirow[t]{7}{*}{4} & Type of School & & \\
\hline & Public & 2 & 66.7 \\
\hline & Parochial & 1 & 33.3 \\
\hline & Device & & \\
\hline & Laptop & 3 & 100.0 \\
\hline & Netbook & 0 & 0.0 \\
\hline & iPad & 0 & 0.0 \\
\hline
\end{tabular}


APPENDIX E 
Table E1

Between Group Effects (Q) by Time Cluster

\begin{tabular}{ccccc}
\hline Time & $n$ & $Q$ & $\mathrm{df}$ & $p$ \\
\hline 1 & 24 & 0.003 & 1 & 0.958 \\
2 & 14 & 0.095 & 1 & 0.758 \\
3 & 4 & 6.998 & 1 & 0.008 \\
4 & 6 & 0.093 & 1 & 0.760 \\
\hline
\end{tabular}

Table E2

Standardized Beta Coefficients ( $\beta$ ) for Regression Models Broken Out by Implementation Time Clusters for Performance Index

\begin{tabular}{cccccccc}
\hline & \multicolumn{2}{c}{ Model with interaction } & & \multicolumn{2}{c}{$\begin{array}{c}\text { Model without } \\
\text { interaction }\end{array}$} \\
\cline { 2 - 3 } $\begin{array}{c}\text { Time } \\
\text { Cluster }\end{array}$ & Time & Group & Interactio & & Time & Group \\
\hline 1 & .046 & 0.128 & 0.063 & & .082 & 0.090 \\
2 & 0.174 & -.145 & -0.102 & & 0.10 & -.106 \\
3 & 0.500 & 0.365 & -0.379 & & 0.23 & 0.331 \\
4 & 0.132 & -0.081 & -0.045 & & .100 & -0.081 \\
\hline
\end{tabular}

Note. $* p<.05, * * p<.001$ 


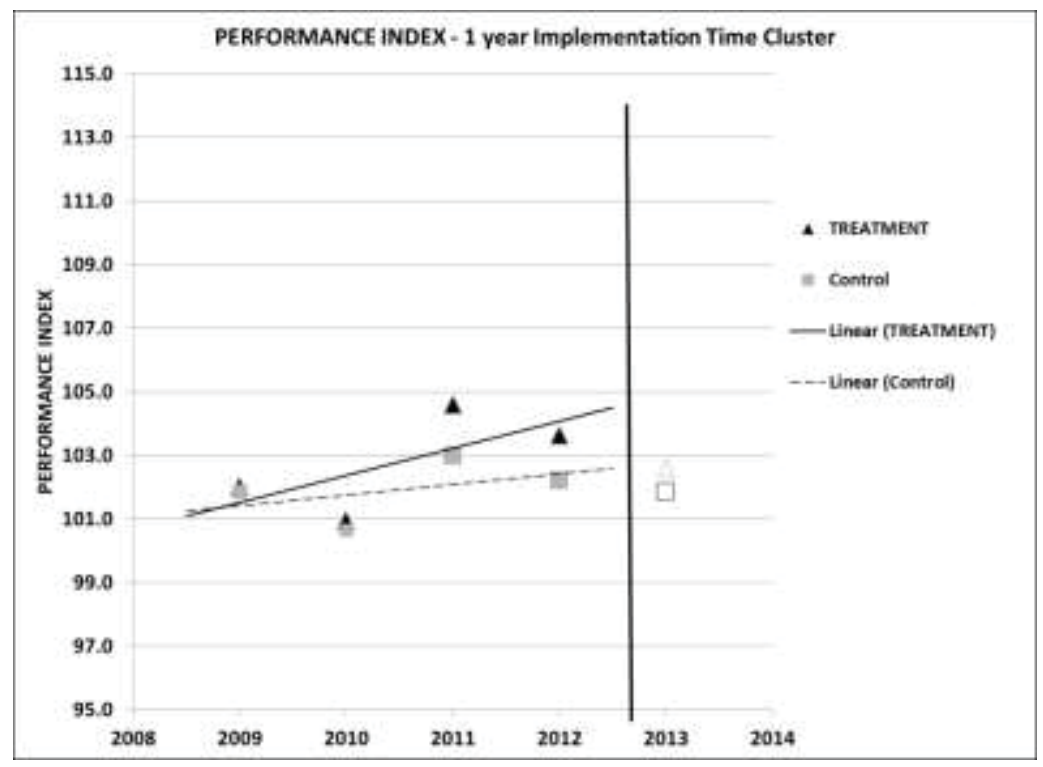

Figure E1. Mean Performance Index Scores across Time for Time Cluster 1 Note. Solid vertical line denotes implementation of the 1:1 program

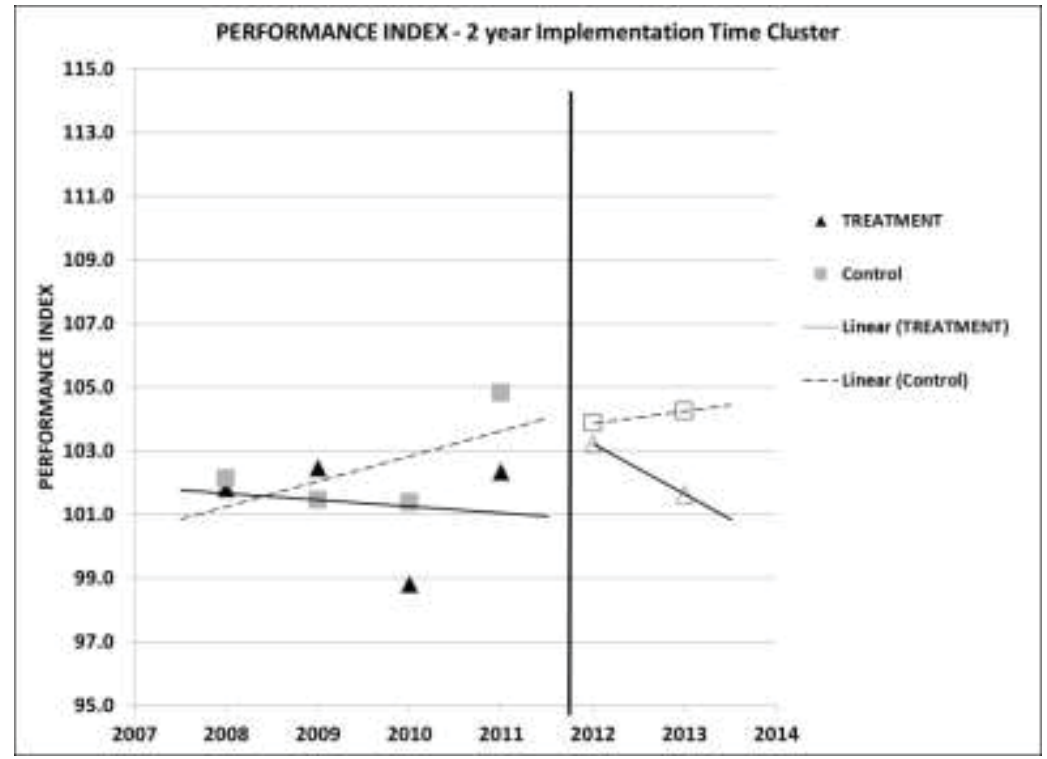

Figure E2. Mean Performance Index Scores across Time for Time Cluster 2 Note. Solid vertical line denotes implementation of the 1:1 program 


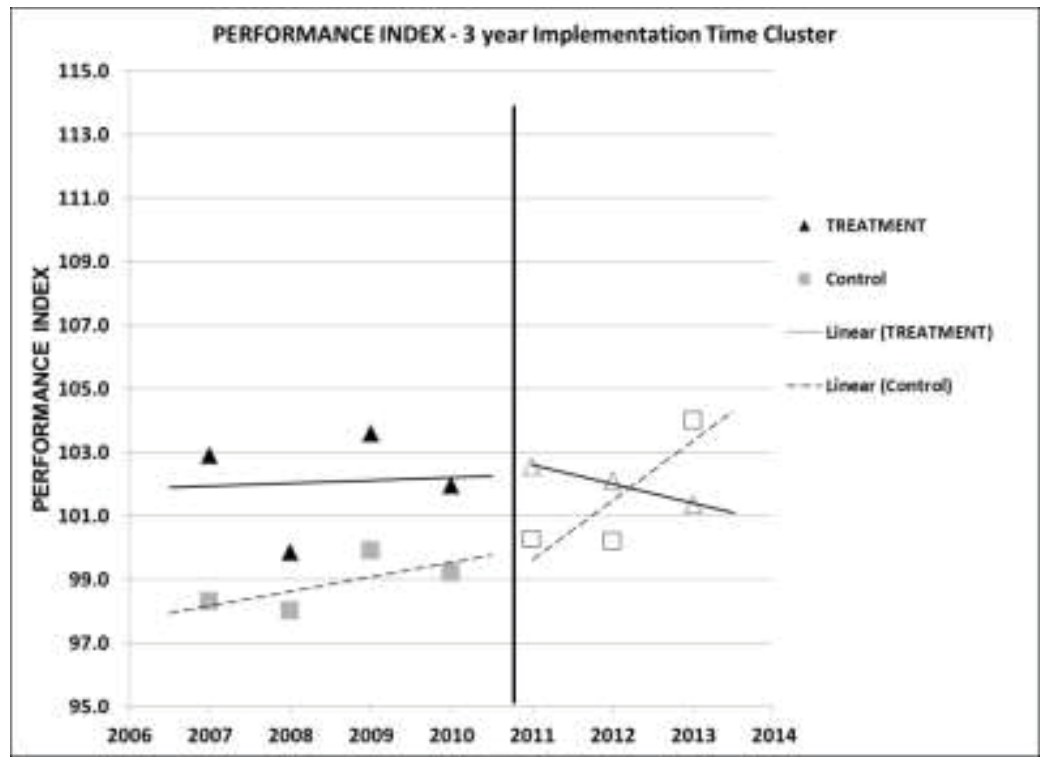

Figure E3. Mean Performance Index Scores across Time for Time Cluster 3 Note. Solid vertical line denotes implementation of the 1:1 program

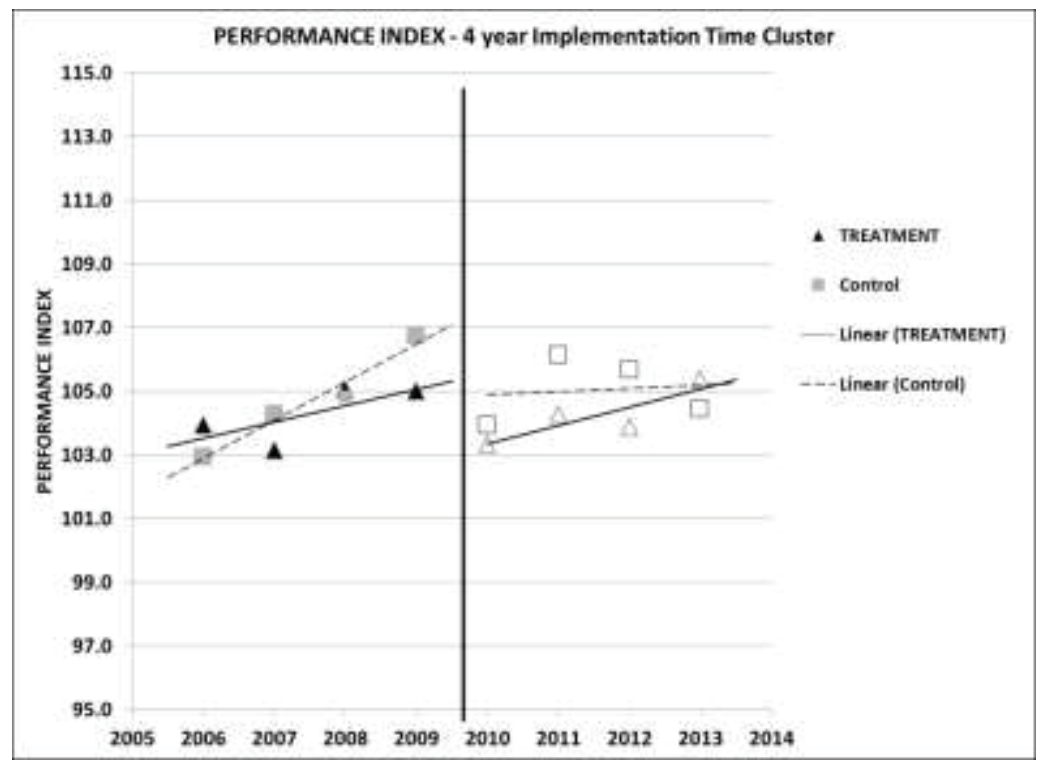

Figure E4. Mean Performance Index Scores across Time for Time Cluster 4 Note. Solid vertical line denotes implementation of the 1:1 program 
APPENDIX F 
Table F1

Standardized Difference in Means for Mathematics

\begin{tabular}{lccccc}
\hline Group & $n$ & $d$ & SE & Lower limit & Upper limit \\
\hline Control & 24 & $0.87^{* *}$ & 0.242 & 0.939 & 1.342 \\
Treatment & 24 & $1.20^{* *}$ & 0.301 & 0.610 & 1.789 \\
\hline Note. ${ }^{*} p<.05, * * p<.001$ & & & &
\end{tabular}

Table F2

Standardized Beta Coefficients ( $\beta$ ) for Regression Models of Math Scaled Scores by Time Cluster

\begin{tabular}{ccccccc}
\hline & \multicolumn{2}{c}{ Model with interaction } & & \multicolumn{2}{c}{$\begin{array}{c}\text { Model without } \\
\text { interaction }\end{array}$} \\
\cline { 2 - 3 } \cline { 6 - 7 } Time Cluster & Time & Group & Interaction & & Time & Group \\
1 & 0.100 & 0.063 & 0.091 & & 0.152 & 0.008 \\
2 & 0.172 & -0.152 & -0.051 & & 0.138 & -0.133 \\
3 & 0.290 & -0.284 & 0.069 & & 0.338 & -0.296 \\
4 & 0.230 & 0.180 & -0.251 & & 0.053 & 0.180 \\
\hline
\end{tabular}

Note. ${ }^{*} p<.05, * * p<.001$ 


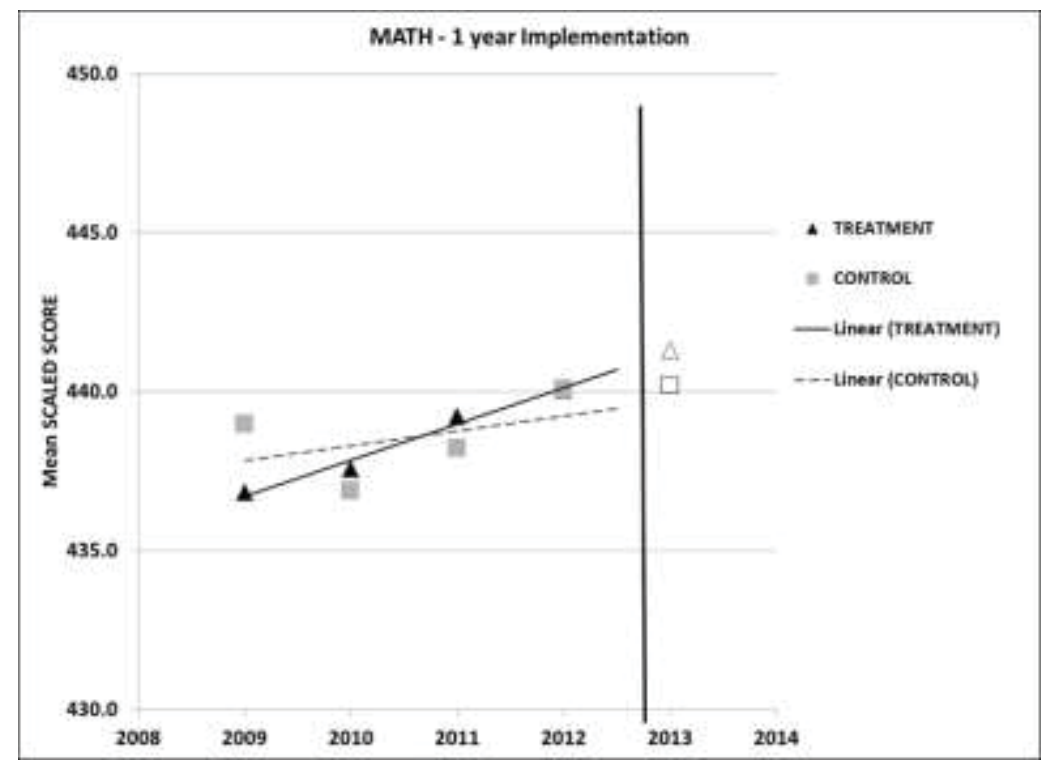

Figure F1. Mathematics Mean Scaled Scores across Time for Time Cluster 1 Note. Solid vertical line denotes implementation of the 1:1 program

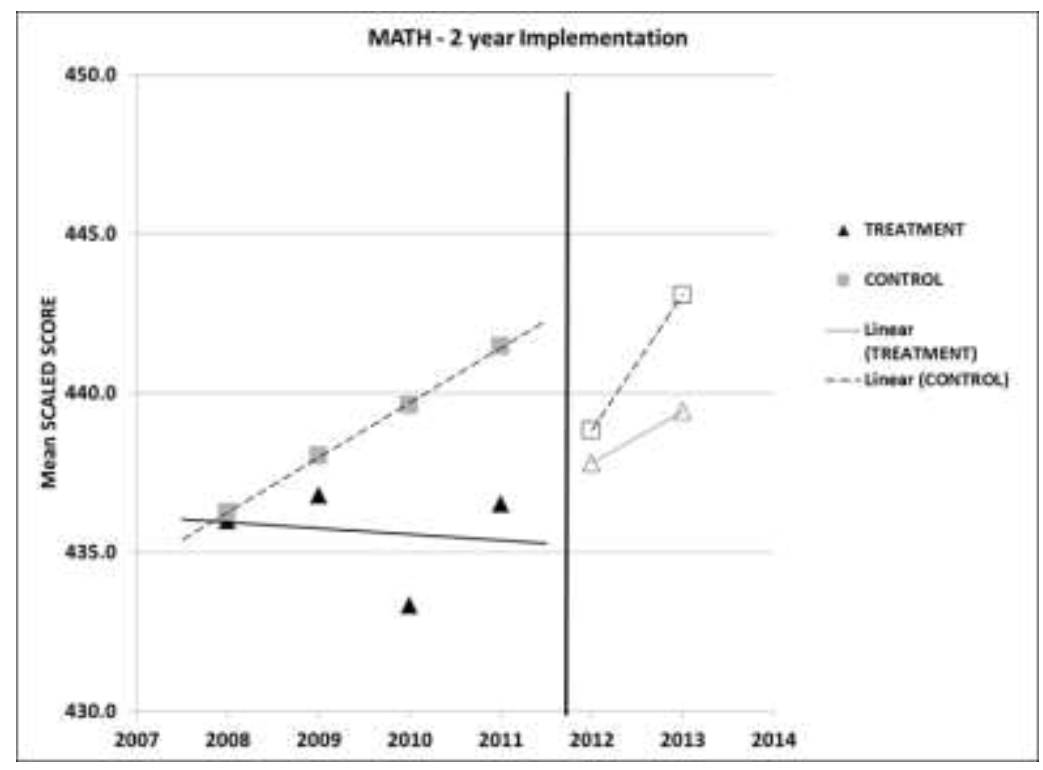

Figure F2. Mathematics Mean Scaled Scores across Time for Time Cluster 2 Note. Solid vertical line denotes implementation of the 1:1 program 


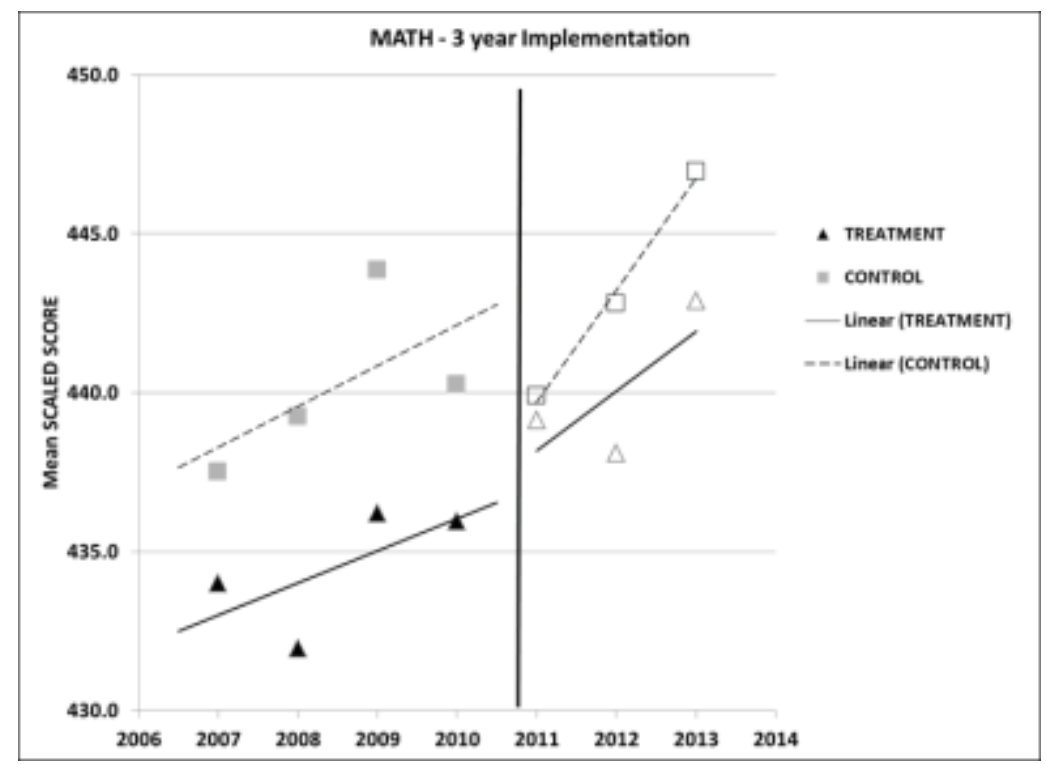

Figure F3. Mathematics Mean Scaled Scores across Time for Time Cluster 3 Note. Solid vertical line denotes implementation of the 1:1 program

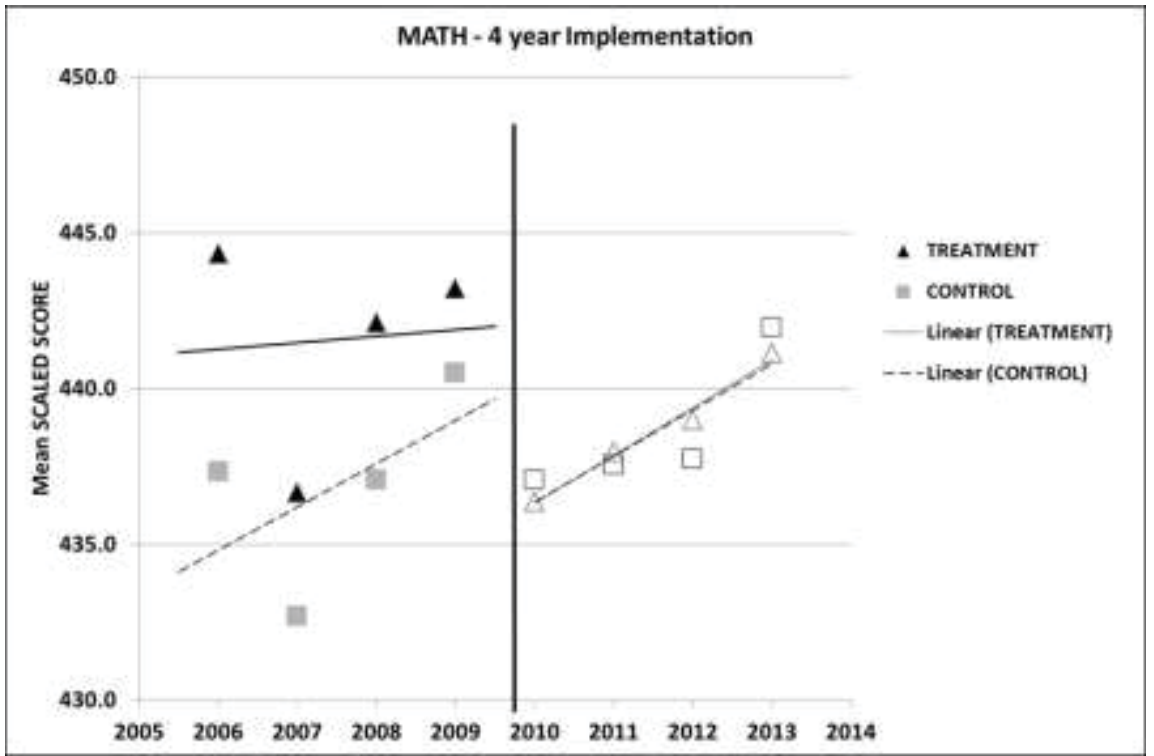

Figure F4. Mathematics Mean Scaled Scores across Time for Time Cluster 4 Note. Solid vertical line denotes implementation of the 1:1 program 
Table F3

Between Group Effects (Q) for Math by Time Cluster

\begin{tabular}{cccc}
\hline Time & $Q$ & df & $p$ \\
\hline 1 & 1.669 & 1 & 0.196 \\
2 & 0.382 & 1 & 0.537 \\
3 & 1.599 & 1 & 0.206 \\
4 & 1.446 & 1 & 0.229 \\
\hline
\end{tabular}


APPENDIX G 
Table G1

Standardized Difference in Means for Reading

\begin{tabular}{lccccc}
\hline Group & $n$ & $d$ & $\mathrm{SE}$ & $\begin{array}{c}\text { Lower } \\
\text { limit }\end{array}$ & $\begin{array}{c}\text { Upper } \\
\text { limit }\end{array}$ \\
\hline Control & 24 & $.69 * *$ & 0.241 & 0.241 & 1.157 \\
Treatment & 24 & 0.58 & 0.300 & -0.007 & 1.168 \\
\hline
\end{tabular}

Note. ${ }^{*} p<.05, * * p<.001$ 


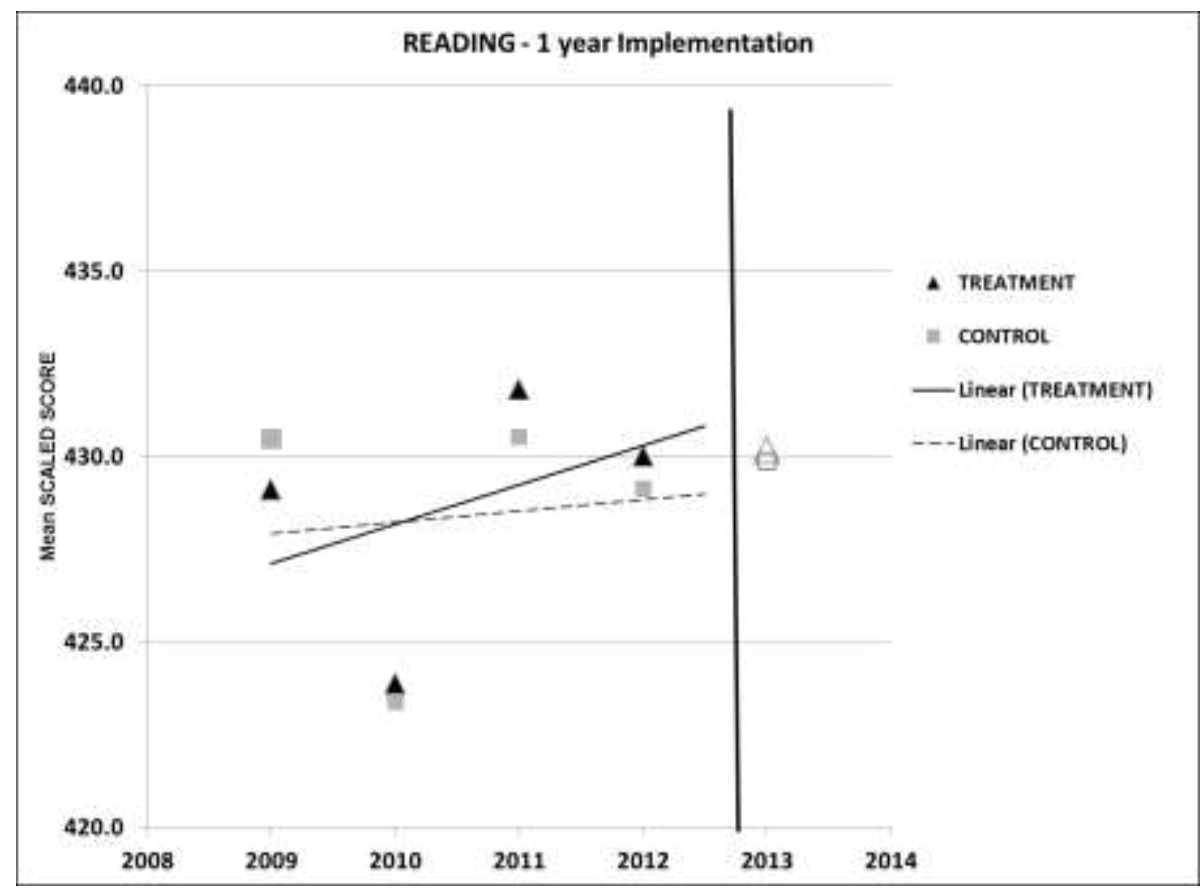

Figure G1. Reading Mean Scaled Scores across Time for Time Cluster 1 Note. Solid vertical line denotes implementation of the 1:1 program

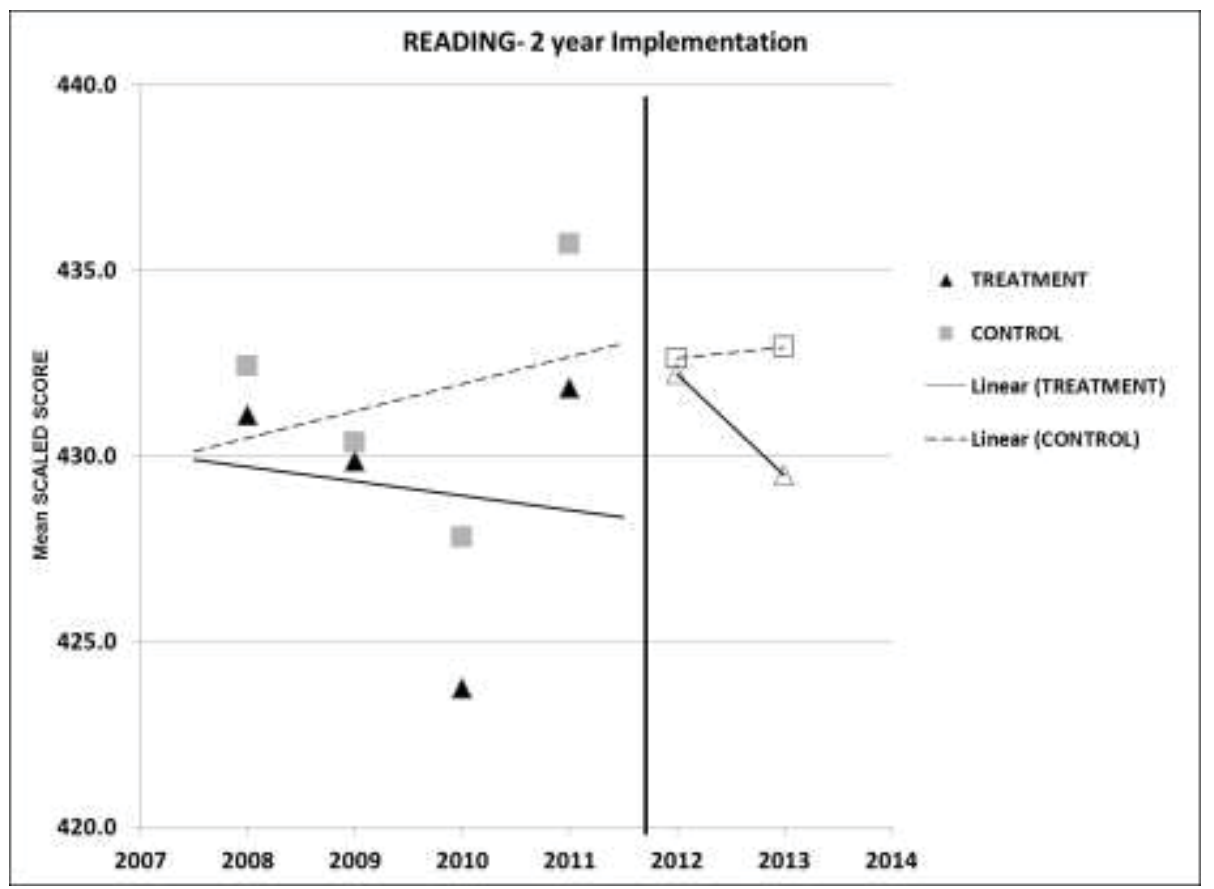

Figure G2. Reading Mean Scaled Scores across Time for Time Cluster 1 Note. Solid vertical line denotes implementation of the 1:1 program 


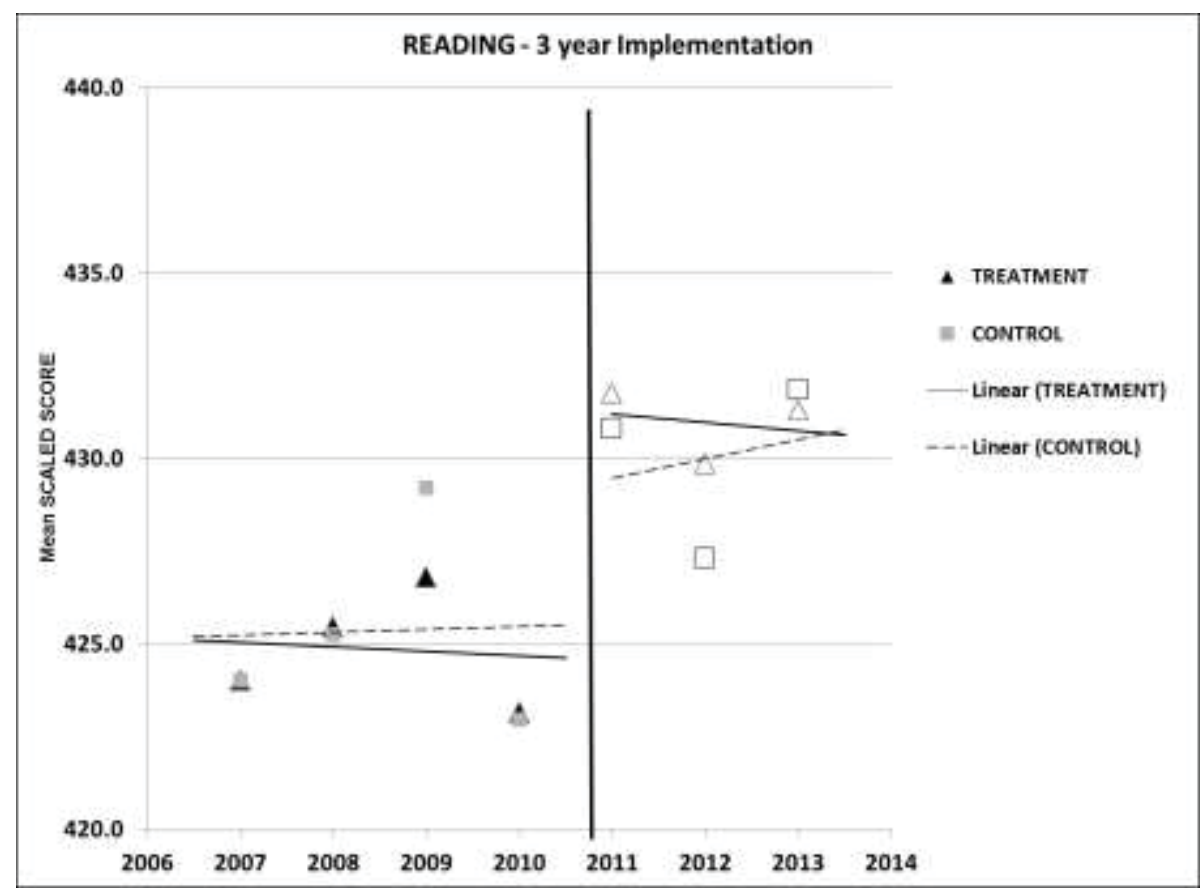

Figure G3. Reading Mean Scaled Scores across Time for Time Cluster 3 Note. Solid vertical line denotes implementation of the 1:1 program

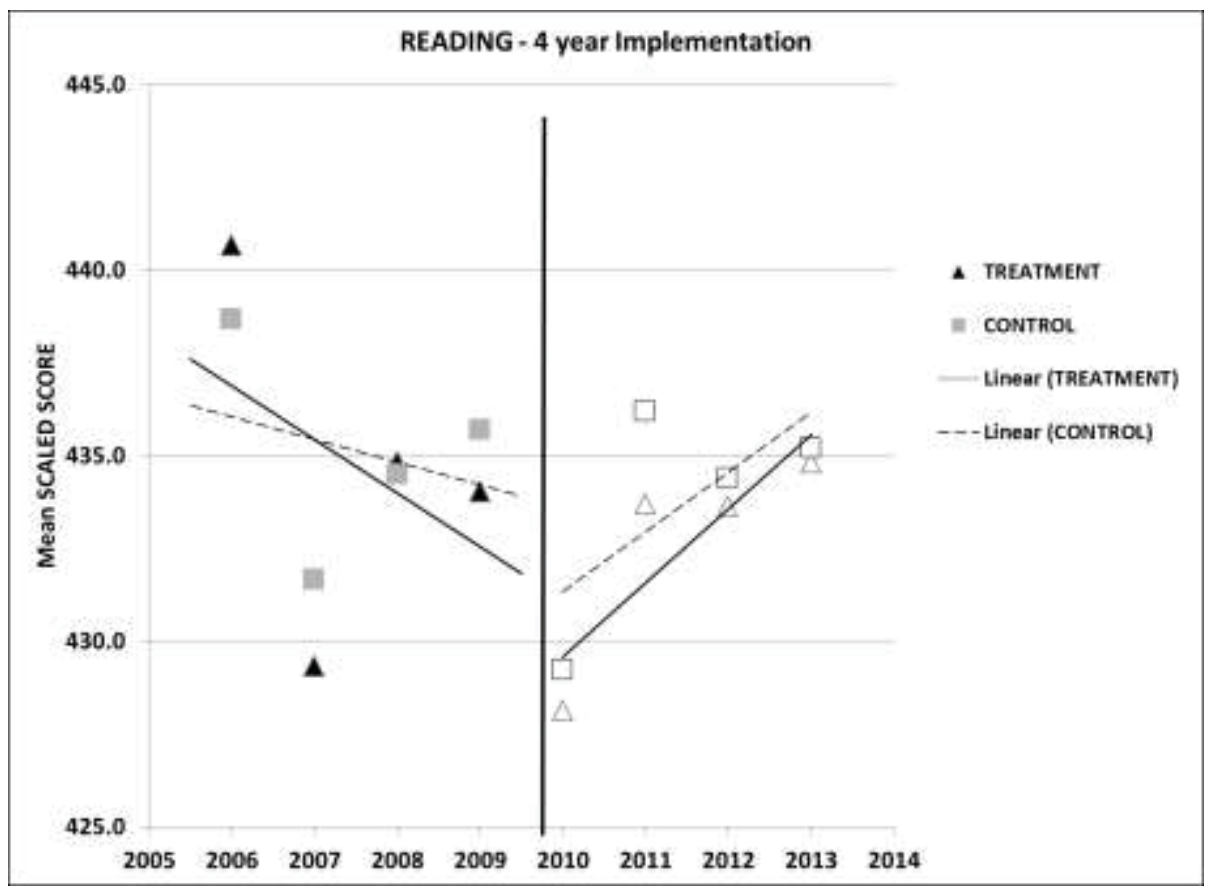

Figure G4. Reading Mean Scaled Scores across Time for Time Cluster 4 Note. Solid vertical line denotes implementation of the 1:1 program 
Table G2

Between Group Effects (Q) for Reading by Time Cluster

\begin{tabular}{crcc}
\hline Time & $Q$ & df & $p$ \\
\hline 1 & 1.666 & 1 & 0.197 \\
2 & 0.176 & 1 & 0.674 \\
3 & 11.938 & 1 & 0.001 \\
4 & 0.071 & 1 & 0.790
\end{tabular}


APPENDIX H 
Table H1

Standardized Difference in Means for Science

\begin{tabular}{lccccc}
\hline Group & $n$ & $d$ & SE & $\begin{array}{c}\text { Lower } \\
\text { limit }\end{array}$ & $\begin{array}{c}\text { Upper } \\
\text { limit }\end{array}$ \\
\hline Control & 24 & $0.49^{*}$ & 0.240 & 0.019 & 0.960 \\
Treatment & 24 & $.98^{* *}$ & 0.301 & 0.394 & 1.574
\end{tabular}

Note. ${ }^{*} p<.05, * * p<.001$ 


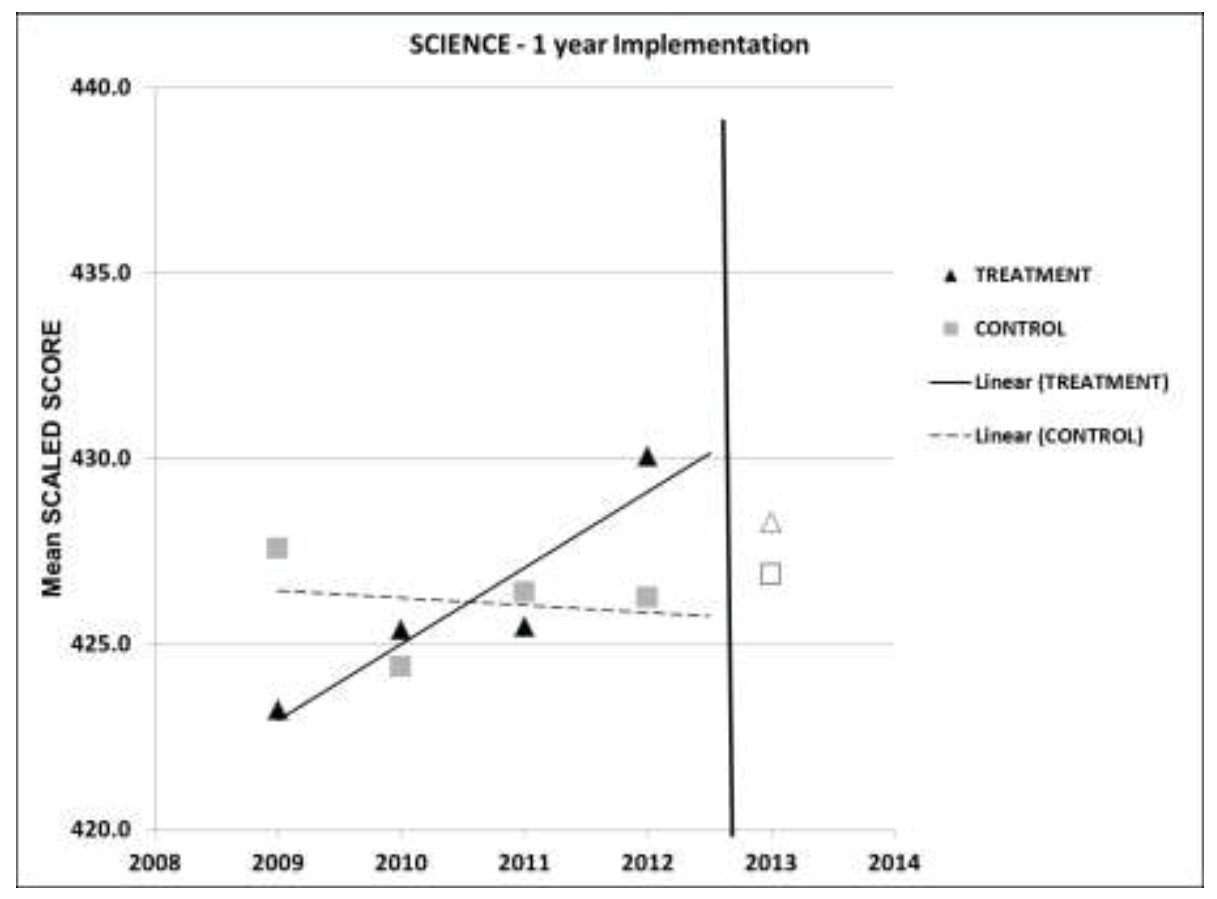

Figure H1. Science Mean Scaled Scores across Time for Time Cluster 1 Note. Solid vertical line denotes implementation of the 1:1 program

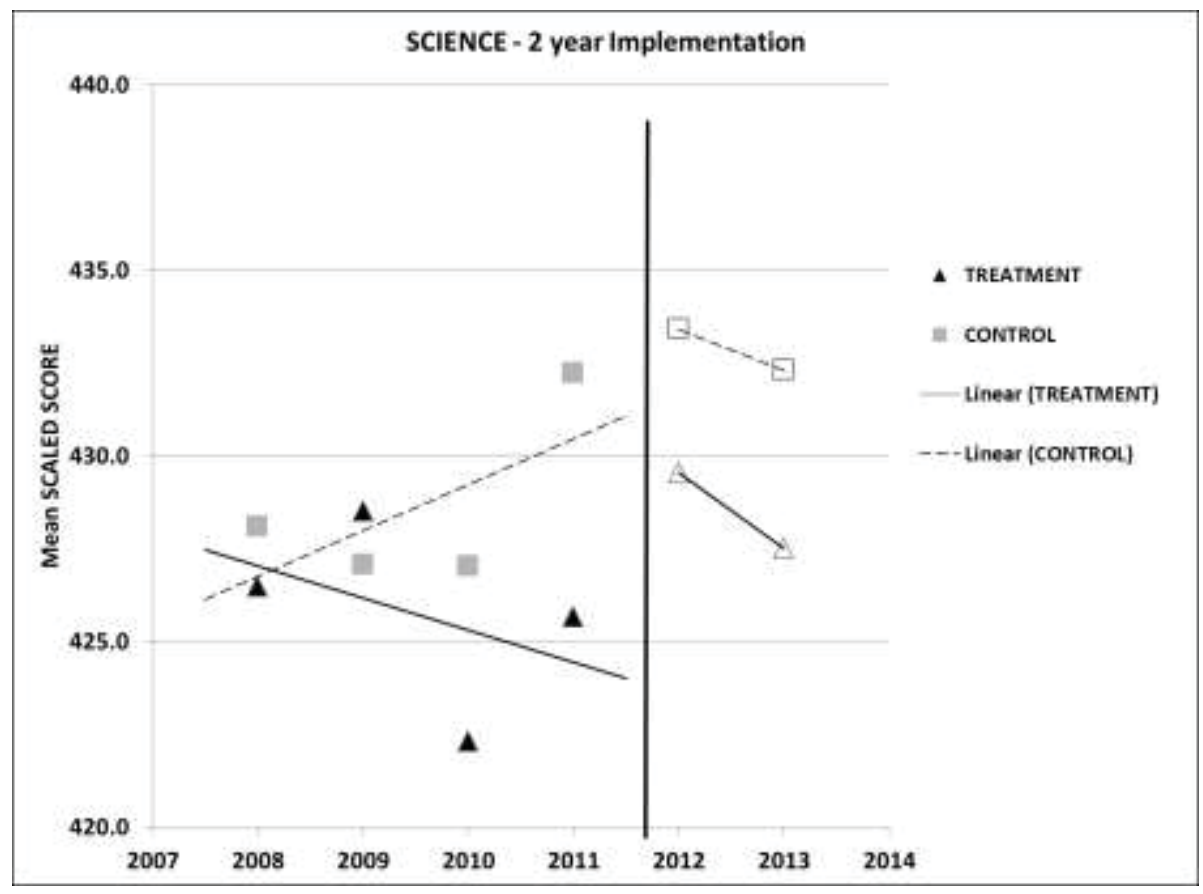

Figure H2. Science Mean Scaled Scores across Time for Time Cluster 2 
Note. Solid vertical line denotes implementation of the 1:1 program

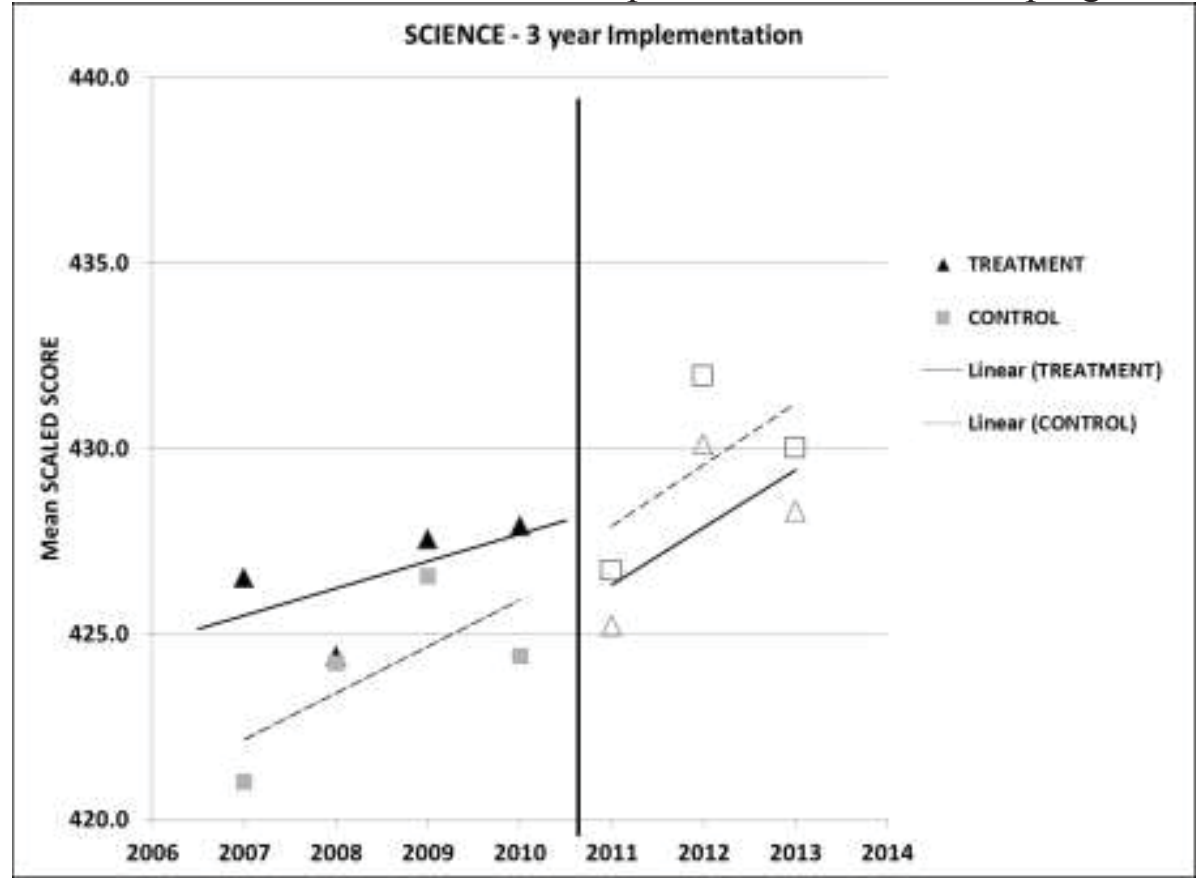

Figure H3. Science Mean Scaled Scores across Time for Time Cluster 3 Note. Solid vertical line denotes implementation of the 1:1 program

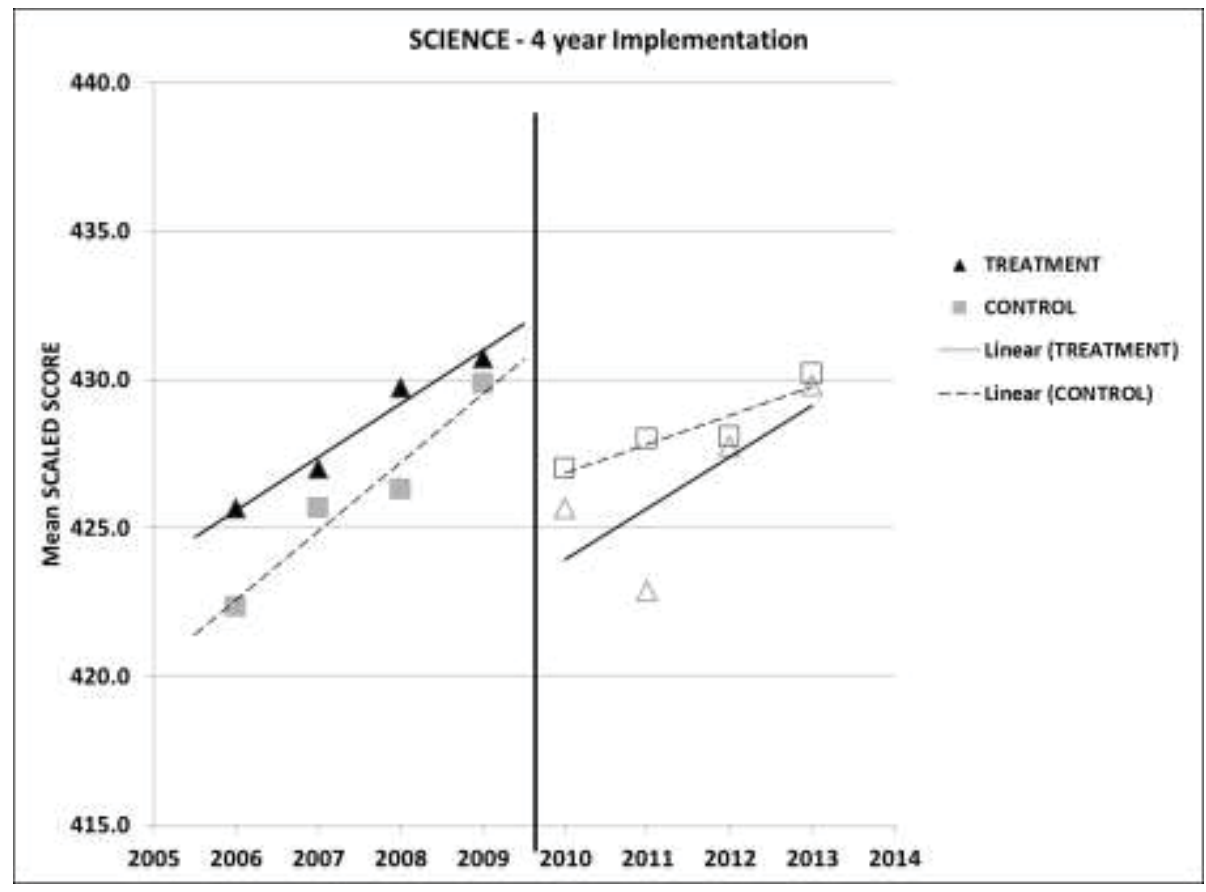

Figure H4. Science Mean Scaled Scores across Time for Time Cluster 4 Note. Solid vertical line denotes implementation of the 1:1 program 
Table H2

Between Group Effects (Q) for Science by Time Cluster

\begin{tabular}{crrc}
\hline Time & $Q$ & df & $p$ \\
\hline 1 & 3.936 & 1 & 0.047 \\
2 & 0.424 & 1 & 0.515 \\
3 & 0.000 & 1 & 0.994 \\
4 & 1.225 & 1 & 0.268 \\
\hline
\end{tabular}


APPENDIX I 
Table I1

Standardized Difference in Means for Social Studies

\begin{tabular}{lccccc}
\hline Group & $n$ & $d$ & SE & $\begin{array}{c}\text { Lower } \\
\text { limit }\end{array}$ & $\begin{array}{c}\text { Upper } \\
\text { limit }\end{array}$ \\
\hline Control & 24 & 0.16 & 0.240 & -0.315 & 0.627 \\
Treatment & 24 & 0.52 & 0.300 & -0.070 & 1.106 \\
\hline
\end{tabular}

$* p<.05, * * p<.001$ 


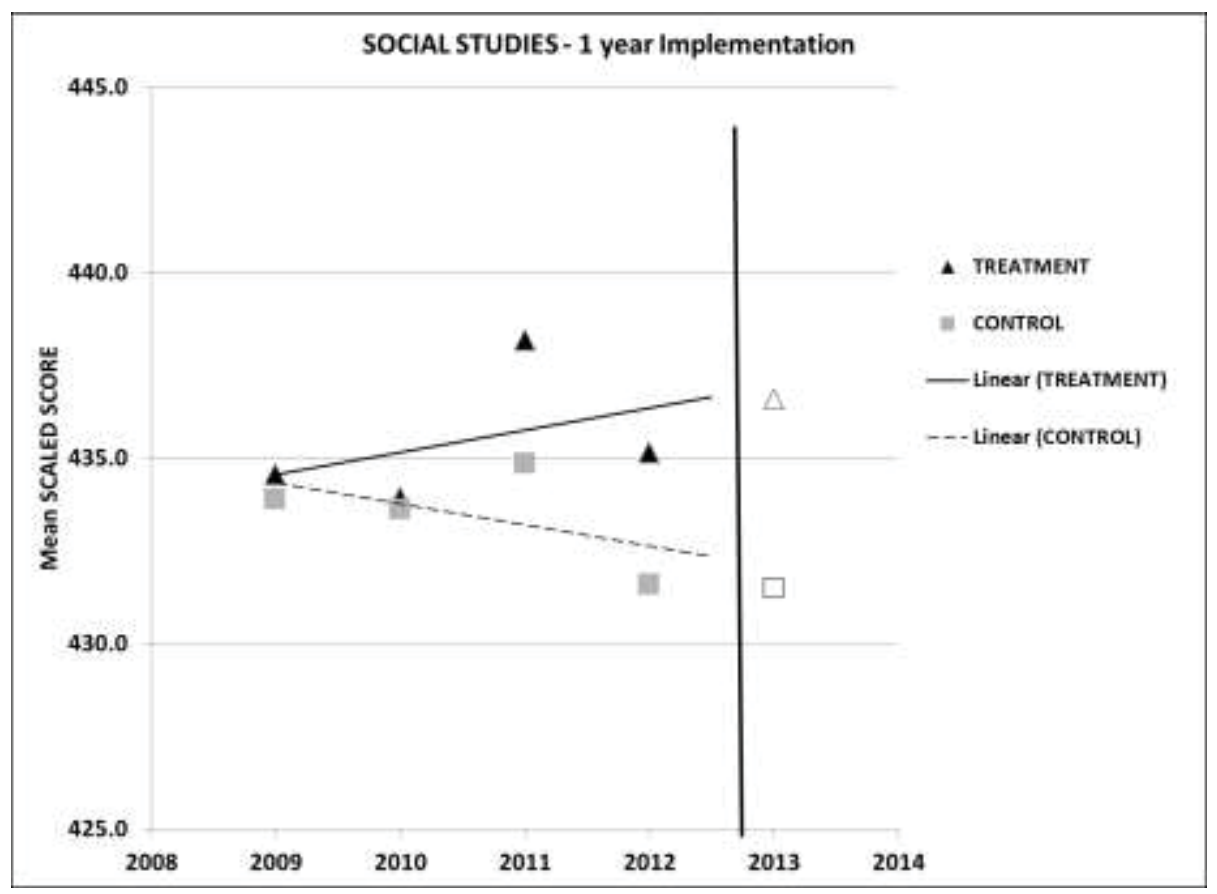

Figure I1. Social Studies Mean Scaled Scores across Time for Time Cluster 1 Note. Solid vertical line denotes implementation of the 1:1 program

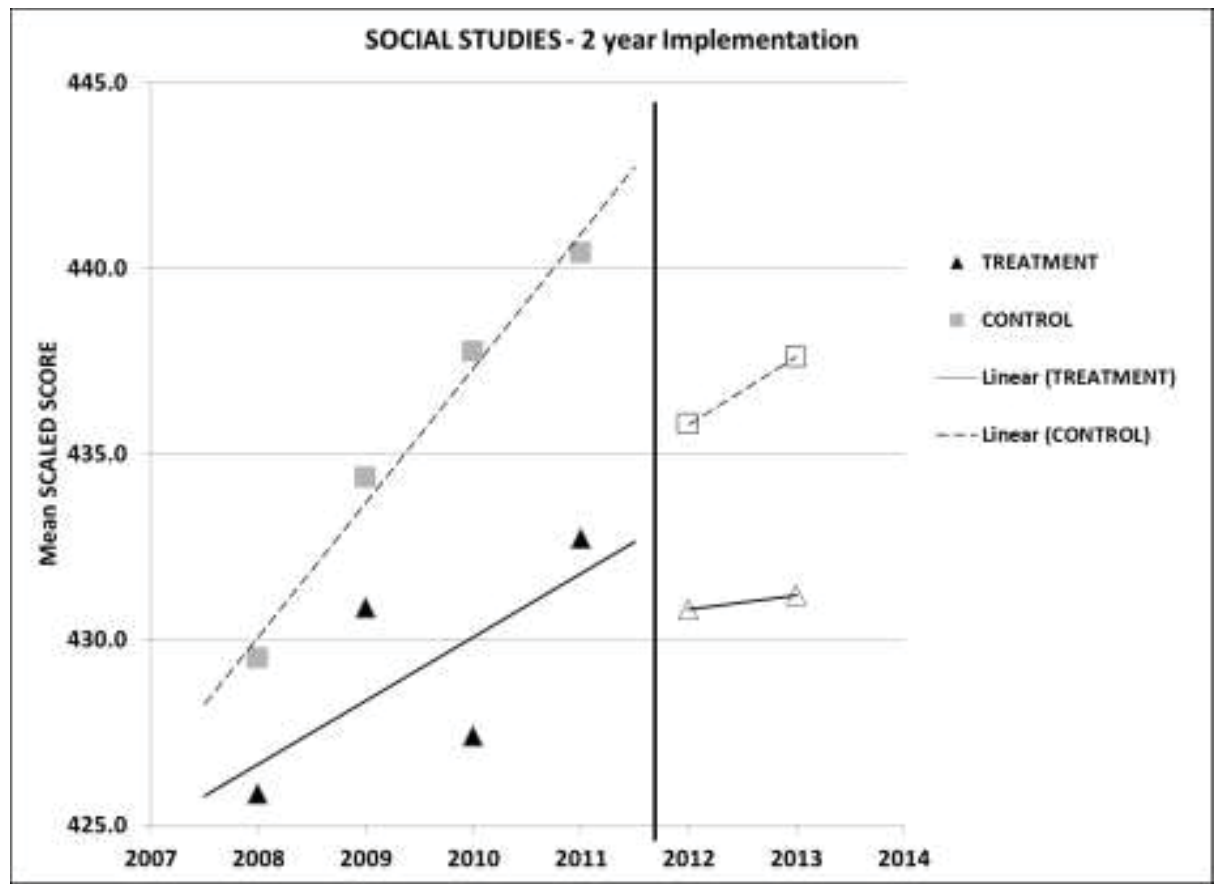

Figure I2. Social Studies Mean Scaled Scores across Time for Time Cluster 2 Note. Solid vertical line denotes implementation of the 1:1 program 


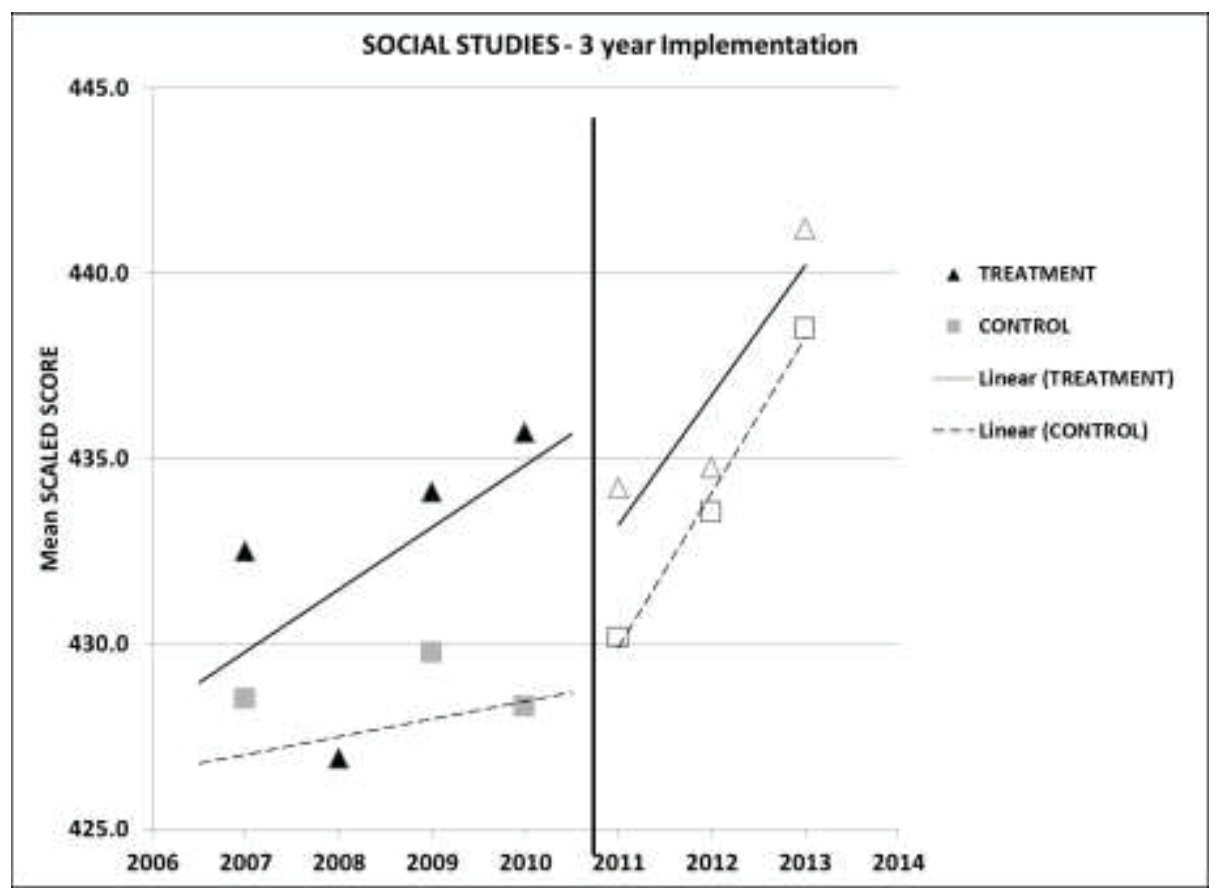

Figure I3. Social Studies Mean Scaled Scores across Time for Time Cluster 3 Note. Solid vertical line denotes implementation of the 1:1 program

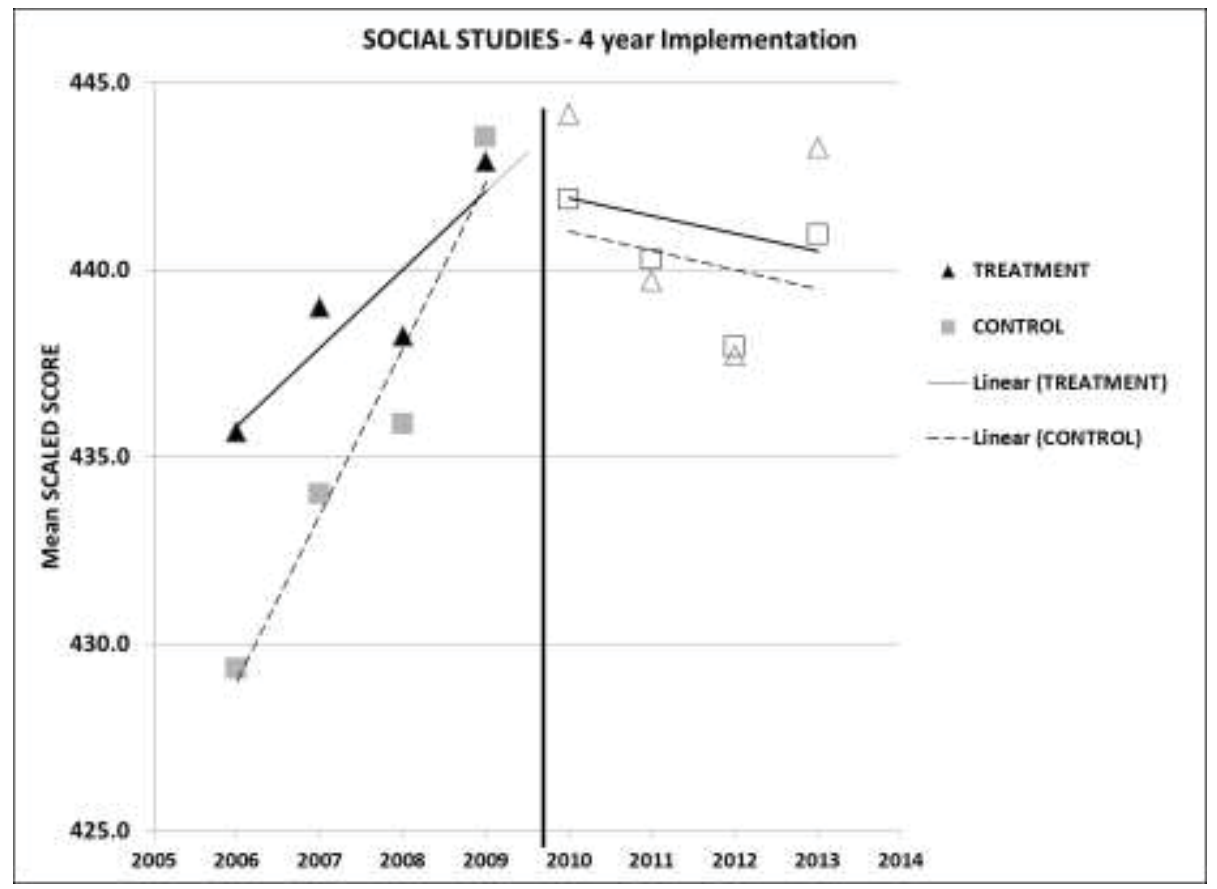

Figure I4. Social Studies Mean Scaled Scores across Time for Time Cluster 4 Note. Solid vertical line denotes implementation of the 1:1 program 
Table I2

Between Group Effects (Q) for Social Studies by Time Cluster

\begin{tabular}{crcc}
\hline Time & $Q$ & df & $p$ \\
\hline 1 & 3.391 & 1 & 0.066 \\
2 & 0.153 & 1 & 0.695 \\
3 & 0.440 & 1 & 0.507 \\
4 & 0.722 & 1 & 0.396
\end{tabular}


APPENDIX J 
Table J1

Standardized Difference in Means for Writing

\begin{tabular}{lccccc}
\hline Group & $n$ & $d$ & $\mathrm{SE}$ & $\begin{array}{c}\text { Lower } \\
\text { limit }\end{array}$ & $\begin{array}{c}\text { Upper } \\
\text { limit }\end{array}$ \\
\hline Control & 24 & $-.85^{* *}$ & 0.240 & -1.324 & -0.382 \\
Treatment & 24 & $-.72^{*}$ & 0.300 & -1.303 & -0.128 \\
\hline
\end{tabular}

$* p<.05, * * p<.001$ 


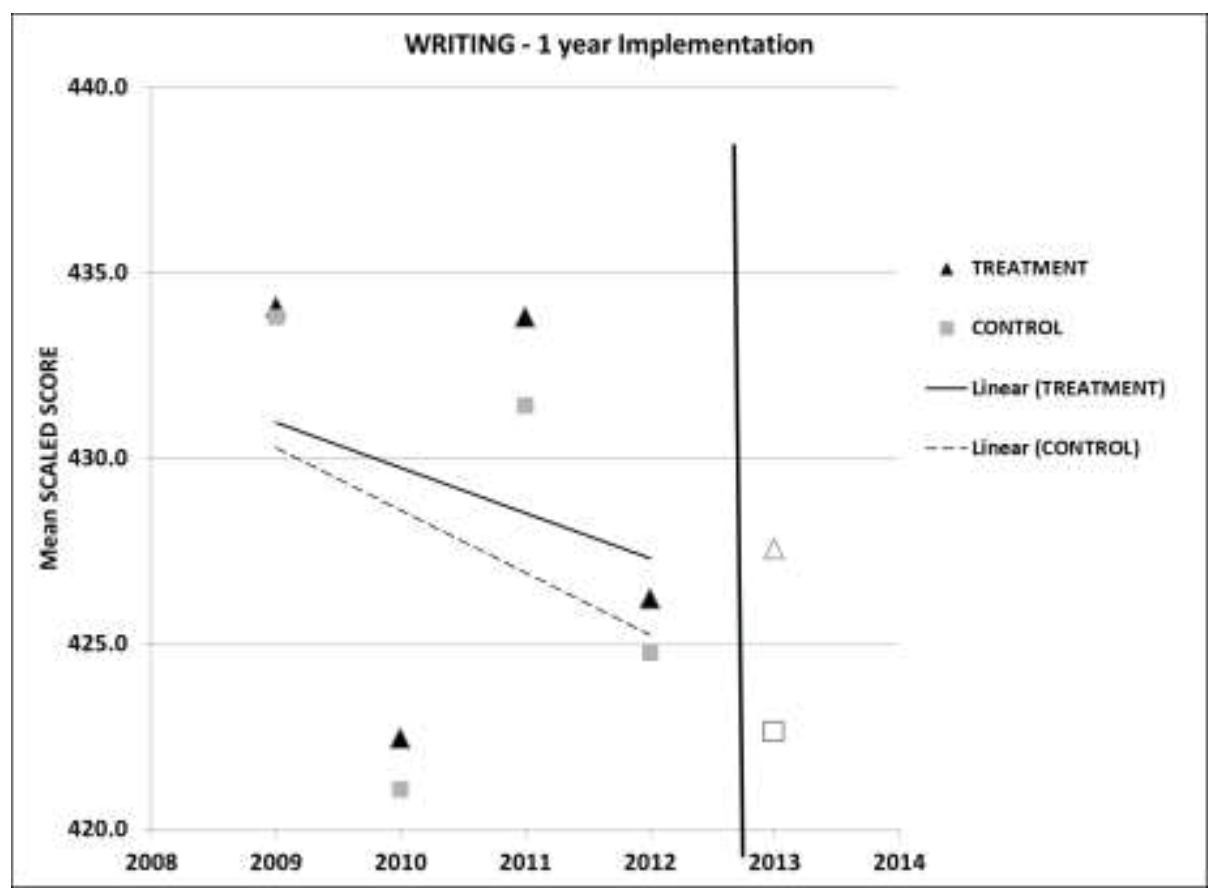

Figure J1. Writing Mean Scaled Scores across Time for Time Cluster 1 Note. Solid vertical line denotes implementation of the 1:1 program

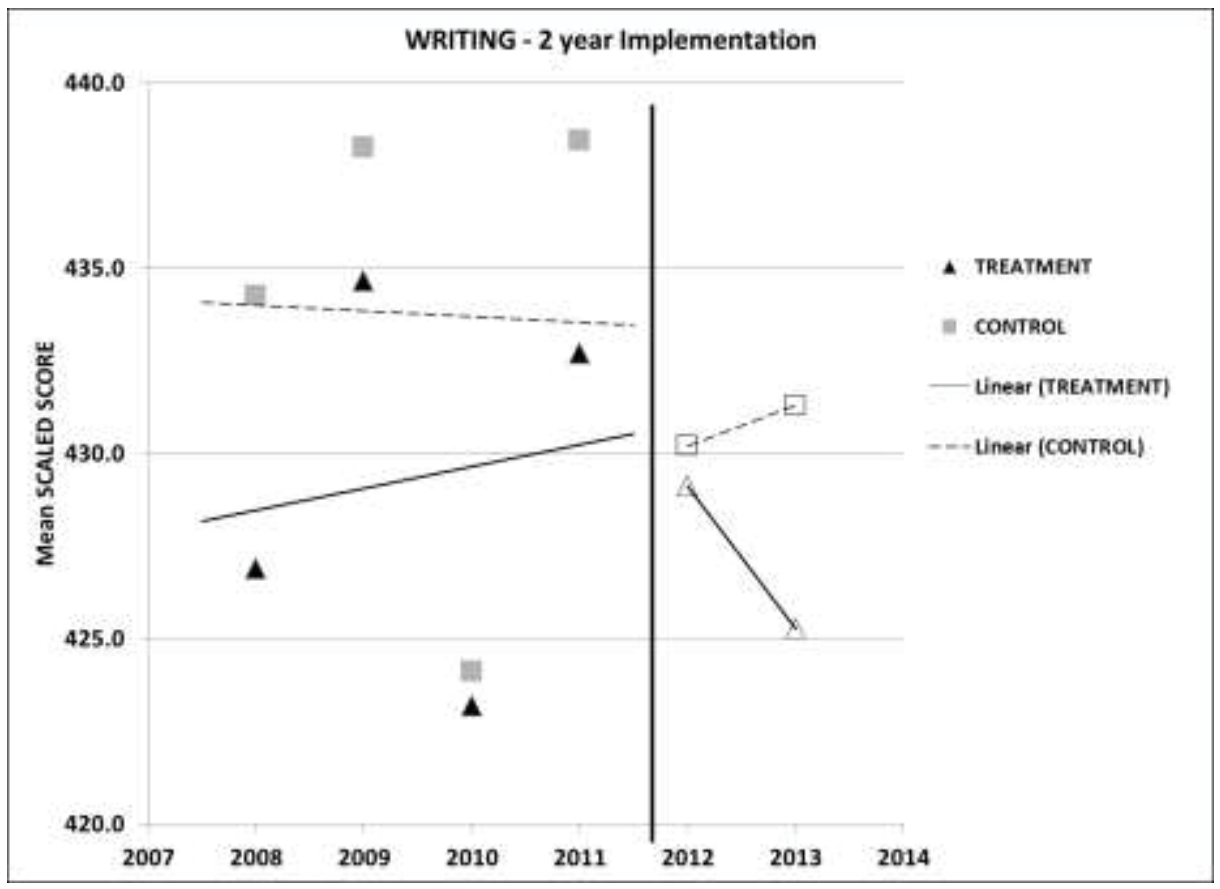

Figure J2. Writing Mean Scaled Scores across Time for Time Cluster 2 Note. Solid vertical line denotes implementation of the 1:1 program 


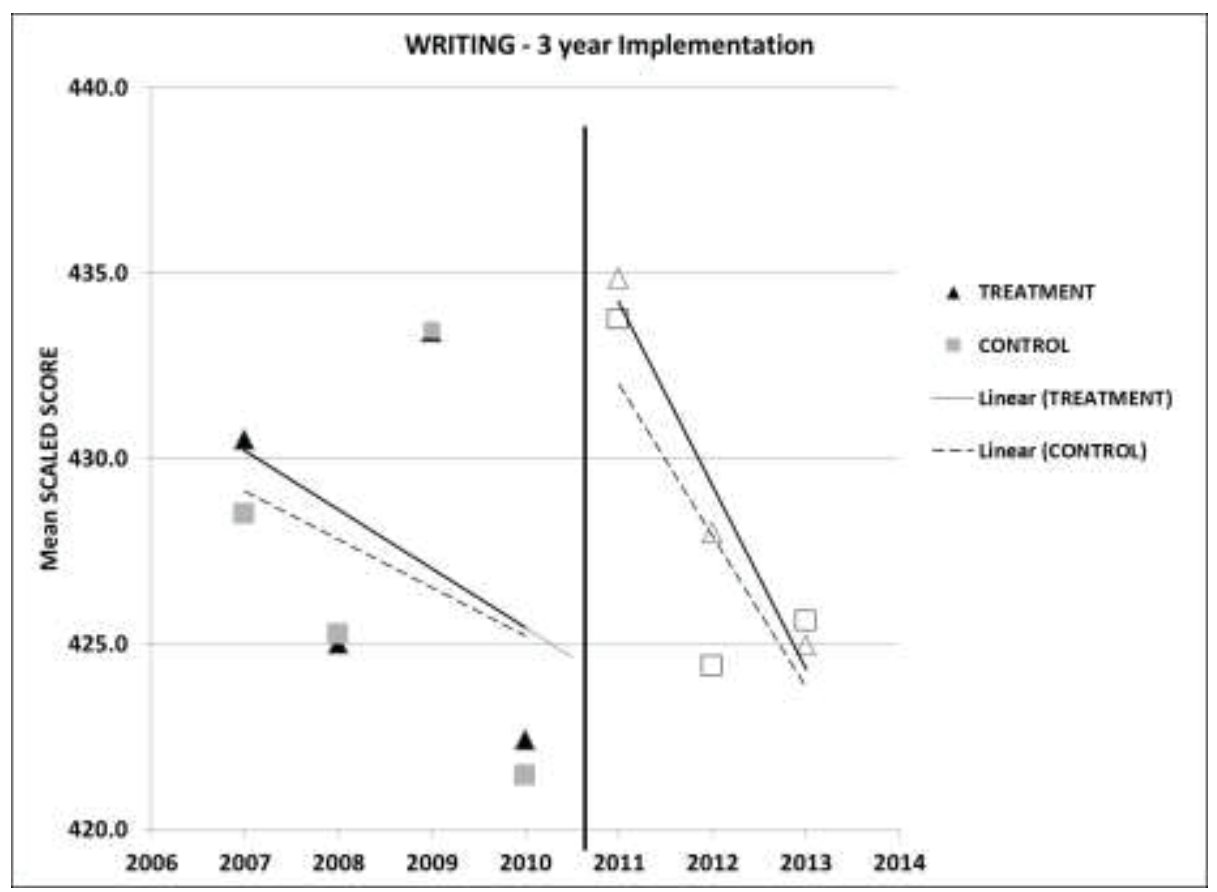

Figure J3. Writing Mean Scaled Scores across Time for Time Cluster 3 Note. Solid vertical line denotes implementation of the 1:1 program

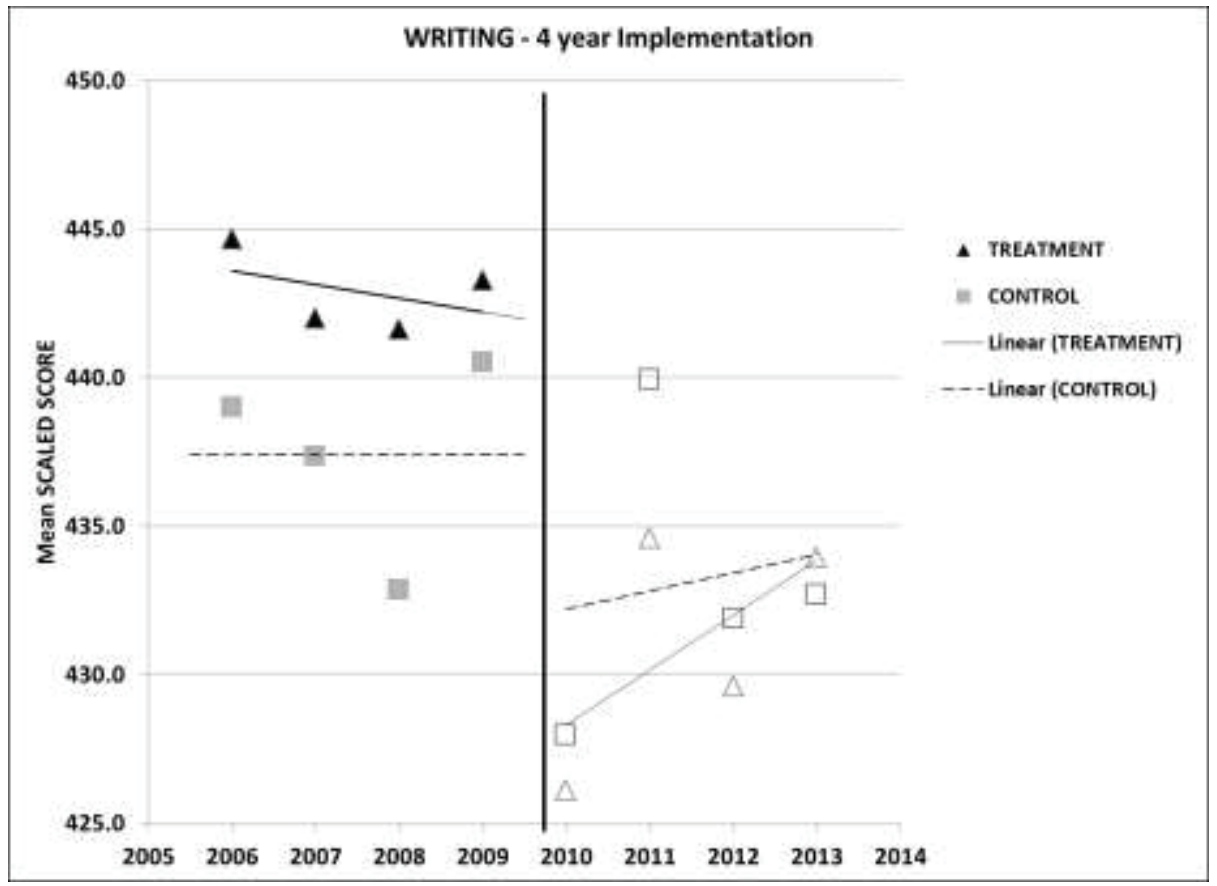

Figure J4. Writing Mean Scaled Scores across Time for Time Cluster 4 Note. Solid vertical line denotes implementation of the 1:1 program 
Table J2

Between Group Effects (Q) for Writing by Time Cluster

\begin{tabular}{crcc}
\hline Time & $Q$ & df & $p$ \\
\hline 1 & 5.990 & 1 & 0.014 \\
2 & 0.072 & 1 & 0.789 \\
3 & 0.462 & 1 & 0.497 \\
4 & 13.652 & 1 & 0.000 \\
\hline
\end{tabular}


Table J3

Between Group Effects (Q) by Time Cluster

\begin{tabular}{|c|c|c|c|c|}
\hline Time & & $Q$ & $\mathrm{df}$ & $p$ \\
\hline \multirow[t]{5}{*}{1} & Math & 1.669 & 1 & 0.196 \\
\hline & Reading & 1.666 & 1 & 0.197 \\
\hline & Science & 3.936 & 1 & 0.047 \\
\hline & Social Studies & 3.391 & 1 & 0.066 \\
\hline & Writing & 5.985 & 1 & 0.014 \\
\hline \multirow[t]{5}{*}{2} & Math & 0.382 & 1 & 0.537 \\
\hline & Reading & 0.176 & 1 & 0.674 \\
\hline & Science & 0.424 & 1 & 0.515 \\
\hline & Social Studies & 0.153 & 1 & 0.695 \\
\hline & Writing & 0.072 & 1 & 0.789 \\
\hline \multirow[t]{5}{*}{3} & Math & 1.599 & 1 & 0.206 \\
\hline & Reading & 11.938 & 1 & 0.001 \\
\hline & Science & 0.000 & 1 & 0.994 \\
\hline & Social Studies & 0.440 & 1 & 0.507 \\
\hline & Writing & 0.462 & 1 & 0.497 \\
\hline \multirow[t]{5}{*}{4} & Math & 1.446 & 1 & 0.229 \\
\hline & Reading & 0.071 & 1 & 0.790 \\
\hline & Science & 1.225 & 1 & 0.268 \\
\hline & Social Studies & 0.722 & 1 & 0.396 \\
\hline & Writing & 13.652 & 1 & 0.000 \\
\hline
\end{tabular}

$* p<.05, * * p<.01$ 
APPENDIX K 
SPSS Output for ANOVA - Overall performance in all content areas (RACE)

Tests of Between-Subjects Effects

Dependent Variable: White SS

\begin{tabular}{|l|r|r|r|r|r|r|}
\hline Source & $\begin{array}{c}\text { Type III Sum of } \\
\text { Squares }\end{array}$ & df & Mean Square & F & Sig. & $\begin{array}{c}\text { Partial } \\
\text { Eta } \\
\text { Squared }\end{array}$ \\
\hline Corrected Model & 498.974 & 3 & 166.325 & 1.892 & .129 & .004 \\
Intercept & $2.265 \mathrm{E} 8$ & 1 & $2.265 \mathrm{E}$ & 2576888.443 & .000 & .999 \\
Group & 22.814 & 1 & 22.814 & .260 & .611 & .000 \\
Period & 470.914 & 1 & 470.914 & 5.358 & .021 & .004 \\
Group * Period & 15.215 & 1 & 15.215 & .173 & .677 & .000 \\
Error & 122699.256 & 1396 & 87.893 & & & \\
Total & $2.626 \mathrm{E}$ & 1400 & & & & \\
Corrected Total & 123198.230 & 1399 & & & & \\
\hline
\end{tabular}

a. R Squared $=.004$ (Adjusted R Squared $=.002$ )

Dependent Variable: Black SS

Tests of Between-Subjects Effects

\begin{tabular}{|l|r|r|r|r|r|r|}
\hline Source & $\begin{array}{r}\text { Type III Sum of } \\
\text { Squares }\end{array}$ & df & Mean Square & F & Sig. & $\begin{array}{c}\text { Partial Eta } \\
\text { Squared }\end{array}$ \\
\hline Corrected Model & $2330.220^{\mathrm{a}}$ & 3 & 776.740 & 5.021 & .002 & .074 \\
Intercept & $3.215 \mathrm{E} 7$ & 1 & $3.215 \mathrm{E} 7$ & 207829.307 & .000 & .999 \\
Group & 2295.151 & 1 & 2295.151 & 14.835 & .000 & .073 \\
Period & 3.335 & 1 & 3.335 & .022 & .883 & .000 \\
Group * Period & 102.041 & 1 & 102.041 & .660 & .418 & .003 \\
Error & 29240.830 & 189 & 154.713 & & & \\
Total & $3.431 \mathrm{E} 7$ & 193 & & & & \\
Corrected Total & 31571.050 & 192 & & & & \\
\hline
\end{tabular}

a. $\mathrm{R}$ Squared $=.074$ (Adjusted R Squared $=.059$ )

Tests of Between-Subjects Effects

Dependent Variable: Other (Combined) SS

\begin{tabular}{|l|r|r|r|r|r|r|}
\hline Source & $\begin{array}{c}\text { Type III Sum of } \\
\text { Squares }\end{array}$ & df & Mean Square & F & Sig. & $\begin{array}{c}\text { Partial } \\
\text { Eta } \\
\text { Squared }\end{array}$ \\
\hline Corrected Model & $2093.036^{2}$ & 3 & 697.679 & 6.657 & .000 & .055 \\
Intercept & $5.690 \mathrm{E} 7$ & 1 & $5.690 \mathrm{E} 7$ & 542962.559 & .000 & .999 \\
Group & 981.835 & 1 & 981.835 & 9.369 & .002 & .027 \\
Period & 552.845 & 1 & 552.845 & 5.275 & .022 & .015 \\
Group * Period & 169.835 & 1 & 169.835 & 1.621 & .204 & .005 \\
Error & 35944.999 & 343 & 104.796 & & & \\
Total & $6.261 \mathrm{E} 7$ & 347 & & & & \\
Corrected Total & 38038.035 & 346 & & & & \\
\hline
\end{tabular}

a. $\quad$ R Squared $=.055$ (Adjusted R Squared $=.047$ ) 
SPSS Output for ANOVA - Performance by Content Area (RACE)

Tests of Between-Subjects Effects

Dependent Variable: White SS

\begin{tabular}{|c|c|c|c|c|c|c|c|}
\hline Content & Source & $\begin{array}{l}\text { Type III Sum } \\
\text { of Squares }\end{array}$ & df & $\begin{array}{l}\text { Mean } \\
\text { Square }\end{array}$ & $\mathrm{F}$ & Sig. & $\begin{array}{l}\text { Partial } \\
\text { Eta } \\
\text { Squared }\end{array}$ \\
\hline \multirow[t]{8}{*}{ Math } & Correct Model & $253.819^{a}$ & 3 & 84.606 & .997 & .394 & .011 \\
\hline & Intercept & 4.677E7 & 1 & 4.677E7 & 551334.459 & .000 & .999 \\
\hline & Group & 24.681 & 1 & 24.681 & .291 & .590 & .001 \\
\hline & Period & 227.752 & 1 & 227.752 & 2.685 & .102 & .010 \\
\hline & Group * Period & .566 & 1 & .566 & .007 & .935 & .000 \\
\hline & Error & 23412.681 & 276 & 84.829 & & & \\
\hline & Total & 5.419E7 & 280 & & & & \\
\hline & Corrected Total & 23666.500 & 279 & & & & \\
\hline \multirow[t]{8}{*}{ Reading } & Correct Model & $212.770^{b}$ & 3 & 70.923 & 1.472 & .222 & .016 \\
\hline & Intercept & 4.486E7 & 1 & 4.486E7 & 931364.184 & .000 & 1.000 \\
\hline & Group & 15.791 & 1 & 15.791 & .328 & .567 & .001 \\
\hline & Period & 194.853 & 1 & 194.853 & 4.045 & .045 & .014 \\
\hline & Group * Period & .015 & 1 & .015 & .000 & .986 & .000 \\
\hline & Error & 13294.193 & 276 & 48.167 & & & \\
\hline & Total & 5.197E7 & 280 & & & & \\
\hline & Corrected Total & 13506.963 & 279 & & & & \\
\hline \multirow[t]{8}{*}{ Science } & Correct Model & $310.270^{c}$ & 3 & 103.423 & 1.681 & .171 & .018 \\
\hline & Intercept & 4.433E7 & 1 & 4.433E7 & 720321.205 & .000 & 1.000 \\
\hline & Group & 18.958 & 1 & 18.958 & .308 & .579 & .001 \\
\hline & Period & 282.311 & 1 & 282.311 & 4.588 & .033 & .016 \\
\hline & Group * Period & 19.383 & 1 & 19.383 & .315 & .575 & .001 \\
\hline & Error & 16984.187 & 276 & 61.537 & & & \\
\hline & Total & $5.134 \mathrm{E} 7$ & 280 & & & & \\
\hline & Corrected Total & 17294.457 & 279 & & & & \\
\hline \multirow{8}{*}{$\begin{array}{l}\text { Social } \\
\text { Studies }\end{array}$} & Correct Model & $345.765^{\mathrm{d}}$ & 3 & 115.255 & 1.474 & .222 & .016 \\
\hline & Intercept & 4.586E7 & 1 & 4.586E7 & 586406.624 & .000 & 1.000 \\
\hline & Group & 3.423 & 1 & 3.423 & .044 & .834 & .000 \\
\hline & Period & 335.584 & 1 & 335.584 & 4.291 & .039 & .015 \\
\hline & Group * Period & 2.981 & 1 & 2.981 & .038 & .845 & .000 \\
\hline & Error & 21585.362 & 276 & 78.208 & & & \\
\hline & Total & 5.312E7 & 280 & & & & \\
\hline & Corrected Total & 21931.127 & 279 & & & & \\
\hline \multirow[t]{8}{*}{ Writing } & Correct Model & $250.087^{\mathrm{e}}$ & 3 & 83.362 & 1.031 & .379 & .011 \\
\hline & Intercept & 4.470E7 & 1 & 4.470E7 & 552692.200 & .000 & 1.000 \\
\hline & Group & .586 & 1 & .586 & .007 & .932 & .000 \\
\hline & Period & 244.847 & 1 & 244.847 & 3.028 & .083 & .011 \\
\hline & Group * Period & 2.954 & 1 & 2.954 & .037 & .849 & .000 \\
\hline & Error & 22319.637 & 276 & 80.868 & & & \\
\hline & Total & 5.196E7 & 280 & & & & \\
\hline & Corrected Total & 22569.724 & 279 & & & & \\
\hline
\end{tabular}

a. R Squared $=.011$ (Adjusted R Squared $=.000)$

b. $\mathrm{R}$ Squared $=.016$ (Adjusted R Squared $=.005)$

c. R Squared $=.018$ (Adjusted R Squared $=.007$ )

d. R Squared $=.016$ (Adjusted R Squared $=.005)$

e. R Squared $=.011$ (Adjusted R Squared $=.000$ ) 
Dependent Variable: Black SS

\section{Tests of Between-Subjects Effects}

\begin{tabular}{|c|c|c|c|c|c|c|c|}
\hline Content & Source & $\begin{array}{l}\text { Type III Sum } \\
\text { of Squares }\end{array}$ & df & Mean Square & $\mathrm{F}$ & Sig. & $\begin{array}{c}\text { Partial } \\
\text { Eta } \\
\text { Squared }\end{array}$ \\
\hline \multirow[t]{8}{*}{ Math } & Correct Model & $254.010^{a}$ & 3 & 84.670 & .567 & .640 & .046 \\
\hline & Intercept & 6469587.808 & 1 & 6469587.808 & 43323.621 & .000 & .999 \\
\hline & Group & 209.904 & 1 & 209.904 & 1.406 & .244 & .039 \\
\hline & Period & 6.560 & 1 & 6.560 & .044 & .835 & .001 \\
\hline & Group * Period & 63.403 & 1 & 63.403 & .425 & .519 & .012 \\
\hline & Error & 5226.608 & 35 & 149.332 & & & \\
\hline & Total & 6916195.720 & 39 & & & & \\
\hline & Corrected Total & 5480.617 & 38 & & & & \\
\hline \multirow[t]{8}{*}{ Reading } & Correct Model & $988.260^{b}$ & 3 & 329.420 & 2.663 & .063 & .186 \\
\hline & Intercept & 6639229.396 & 1 & 6639229.396 & 53670.584 & .000 & .999 \\
\hline & Group & 957.367 & 1 & 957.367 & 7.739 & .009 & 181 \\
\hline & Period & 3.803 & 1 & 3.803 & .031 & .862 & .001 \\
\hline & Group * Period & 697 & 1 & .697 & .006 & .941 & .000 \\
\hline & Error & 4329.616 & 35 & 123.703 & & & \\
\hline & Total & 7073257.550 & 39 & & & & \\
\hline & Corrected Total & 5317.876 & 38 & & & & \\
\hline \multirow[t]{8}{*}{ Science } & Correct Model & $760.068^{c}$ & 3 & 253.356 & 2.176 & .108 & .157 \\
\hline & Intercept & 6203529.241 & 1 & 6203529.241 & 53283.094 & .000 & .999 \\
\hline & Group & 660.543 & 1 & 660.543 & 5.674 & .023 & .139 \\
\hline & Period & 84.547 & 1 & 84.547 & .726 & .400 & .020 \\
\hline & Group * Period & 10.370 & 1 & 10.370 & .089 & .767 & .003 \\
\hline & Error & 4074.905 & 35 & 116.426 & & & \\
\hline & Total & 6610768.070 & 39 & & & & \\
\hline & Corrected Total & 4834.972 & 38 & & & & \\
\hline \multirow[t]{8}{*}{ Social Studies } & Correct Model & $269.639^{d}$ & 3 & 89.880 & .637 & .596 & .053 \\
\hline & Intercept & 6477134.360 & 1 & 6477134.360 & 45932.013 & .000 & .999 \\
\hline & Group & 210.749 & 1 & 210.749 & 1.495 & .230 & .042 \\
\hline & Period & 9.478 & 1 & 9.478 & .067 & .797 & .002 \\
\hline & Group * Period & 58.634 & 1 & 58.634 & .416 & .523 & .012 \\
\hline & Error & 4794.533 & 34 & 141.016 & & & \\
\hline & Total & 6834686.700 & 38 & & & & \\
\hline & Corrected Total & 5064.173 & 37 & & & & \\
\hline \multirow[t]{8}{*}{ Writing } & Correct Model & $545.384^{\mathrm{e}}$ & 3 & 181.795 & 1.224 & .316 & .097 \\
\hline & Intercept & 6348167.280 & 1 & 6348167.280 & 42736.862 & .000 & .999 \\
\hline & Group & 483.600 & 1 & 483.600 & 3.256 & .080 & .087 \\
\hline & Period & 61.381 & 1 & 61.381 & .413 & .525 & .012 \\
\hline & Group * Period & 16.252 & 1 & 16.252 & .109 & .743 & .003 \\
\hline & Error & 5050.387 & 34 & 148.541 & & & \\
\hline & Total & 6873086.280 & 38 & & & & \\
\hline & Corrected Total & 5595.771 & 37 & & & & \\
\hline
\end{tabular}

a. $\mathrm{R}$ Squared $=.046$ (Adjusted R Squared $=-.035$ )

b. $\mathrm{R}$ Squared $=.186$ (Adjusted R Squared $=.116)$

c. $R$ Squared $=.157$ (Adjusted R Squared $=.085$ )

d. $\mathrm{R}$ Squared $=.053$ (Adjusted R Squared $=-.030$ ) 
Tests of Between-Subjects Effects

Dependent OTHER SS

\begin{tabular}{|c|c|c|c|c|c|c|c|}
\hline Content & Source & $\begin{array}{l}\text { Type III Sum } \\
\text { of Squares }\end{array}$ & df & $\begin{array}{l}\text { Mean } \\
\text { Square }\end{array}$ & $\mathrm{F}$ & Sig. & $\begin{array}{c}\text { Partial } \\
\text { Eta } \\
\text { Squared }\end{array}$ \\
\hline \multirow[t]{8}{*}{ Math } & Corrected Model & $741.580^{\mathrm{a}}$ & 3 & 247.193 & 2.575 & .061 & .105 \\
\hline & Intercept & 1.172E7 & 1 & 1.172E7 & 122121.476 & .000 & .999 \\
\hline & Group & 73.403 & 1 & 73.403 & .765 & .385 & .011 \\
\hline & Period & 431.223 & 1 & 431.223 & 4.492 & .038 & .064 \\
\hline & Group * Period & 178.209 & 1 & 178.209 & 1.857 & .178 & .027 \\
\hline & Error & 6335.249 & 66 & 95.989 & & & \\
\hline & Total & $1.287 \mathrm{E} 7$ & 70 & & & & \\
\hline & Corrected Total & 7076.828 & 69 & & & & \\
\hline \multirow[t]{8}{*}{ Reading } & Corrected Model & $254.133^{b}$ & 3 & 84.711 & 1.058 & .373 & .047 \\
\hline & Intercept & 1.145E7 & 1 & 1.145E7 & 143089.362 & .000 & 1.000 \\
\hline & Group & 115.648 & 1 & 115.648 & 1.445 & .234 & .022 \\
\hline & Period & 109.468 & 1 & 109.468 & 1.368 & .246 & .021 \\
\hline & Group * Period & 2.167 & 1 & 2.167 & .027 & .870 & .000 \\
\hline & Error & 5202.420 & 65 & 80.037 & & & \\
\hline & Total & $1.251 \mathrm{E} 7$ & 69 & & & & \\
\hline & Corrected Total & 5456.552 & 68 & & & & \\
\hline \multirow[t]{8}{*}{ Science } & Corrected Model & $335.776^{c}$ & 3 & 111.925 & 1.125 & .346 & .049 \\
\hline & Intercept & 1.070E7 & 1 & 1.070E7 & 107596.730 & .000 & .999 \\
\hline & Group & 122.212 & 1 & 122.212 & 1.228 & .272 & .019 \\
\hline & Period & 106.441 & 1 & 106.441 & 1.070 & .305 & .016 \\
\hline & Group * Period & 35.883 & 1 & 35.883 & .361 & .550 & .006 \\
\hline & Error & 6466.959 & 65 & 99.492 & & & \\
\hline & Total & $1.201 \mathrm{E} 7$ & 69 & & & & \\
\hline & Corrected Total & 6802.736 & 68 & & & & \\
\hline \multirow{8}{*}{$\begin{array}{l}\text { Social } \\
\text { Studies }\end{array}$} & Corrected Model & $486.652^{d}$ & 3 & 162.217 & 1.449 & .237 & .063 \\
\hline & Intercept & 1.149E7 & 1 & 1.149E7 & 102671.329 & .000 & .999 \\
\hline & Group & 205.082 & 1 & 205.082 & 1.832 & .181 & .027 \\
\hline & Period & 200.654 & 1 & 200.654 & 1.792 & .185 & .027 \\
\hline & Group * Period & 17.676 & 1 & 17.676 & .158 & .692 & .002 \\
\hline & Error & 7276.850 & 65 & 111.952 & & & \\
\hline & Total & $1.255 \mathrm{E} 7$ & 69 & & & & \\
\hline & Corrected Total & 7763.503 & 68 & & & & \\
\hline \multirow[t]{8}{*}{ Writing } & Corrected Model & $779.999^{\mathrm{e}}$ & 3 & 260.000 & 3.651 & .017 & .142 \\
\hline & Intercept & $1.151 \mathrm{E} 7$ & 1 & $1.151 \mathrm{E} 7$ & 161617.524 & .000 & 1.000 \\
\hline & Group & 667.853 & 1 & 667.853 & 9.379 & .003 & .124 \\
\hline & Period & 22.584 & 1 & 22.584 & .317 & .575 & .005 \\
\hline & Group * Period & 3.839 & 1 & 3.839 & .054 & .817 & .001 \\
\hline & Error & 4699.567 & 66 & 71.206 & & & \\
\hline & Total & $1.268 \mathrm{E} 7$ & 70 & & & & \\
\hline & Corrected Total & 5479.566 & 69 & & & & \\
\hline
\end{tabular}

a. R Squared $=.105$ (Adjusted $R$ Squared $=.064$ )

b. $\mathrm{R}$ Squared $=.047$ (Adjusted R Squared $=.003$ )

c. R Squared $=.049$ (Adjusted R Squared $=.005$ )

d. R Squared $=.063$ (Adjusted R Squared $=.019$ ) 
Dependent Variable: Black SS

\section{Tests of Between-Subjects Effects}

\begin{tabular}{|c|c|c|c|c|c|c|c|}
\hline Content & Source & $\begin{array}{l}\text { Type III Sum } \\
\text { of Squares }\end{array}$ & df & Mean Square & $\mathrm{F}$ & Sig. & $\begin{array}{c}\text { Partial } \\
\text { Eta } \\
\text { Squared }\end{array}$ \\
\hline \multirow[t]{8}{*}{ Math } & Correct Model & $254.010^{a}$ & 3 & 84.670 & .567 & .640 & .046 \\
\hline & Intercept & 6469587.808 & 1 & 6469587.808 & 43323.621 & .000 & .999 \\
\hline & Group & 209.904 & 1 & 209.904 & 1.406 & .244 & .039 \\
\hline & Period & 6.560 & 1 & 6.560 & .044 & .835 & .001 \\
\hline & Group * Period & 63.403 & 1 & 63.403 & .425 & .519 & .012 \\
\hline & Error & 5226.608 & 35 & 149.332 & & & \\
\hline & Total & 6916195.720 & 39 & & & & \\
\hline & Corrected Total & 5480.617 & 38 & & & & \\
\hline \multirow[t]{8}{*}{ Reading } & Correct Model & $988.260^{b}$ & 3 & 329.420 & 2.663 & .063 & .186 \\
\hline & Intercept & 6639229.396 & 1 & 6639229.396 & 53670.584 & .000 & .999 \\
\hline & Group & 957.367 & 1 & 957.367 & 7.739 & .009 & 181 \\
\hline & Period & 3.803 & 1 & 3.803 & .031 & .862 & .001 \\
\hline & Group * Period & 697 & 1 & .697 & .006 & .941 & .000 \\
\hline & Error & 4329.616 & 35 & 123.703 & & & \\
\hline & Total & 7073257.550 & 39 & & & & \\
\hline & Corrected Total & 5317.876 & 38 & & & & \\
\hline \multirow[t]{8}{*}{ Science } & Correct Model & $760.068^{c}$ & 3 & 253.356 & 2.176 & .108 & .157 \\
\hline & Intercept & 6203529.241 & 1 & 6203529.241 & 53283.094 & .000 & .999 \\
\hline & Group & 660.543 & 1 & 660.543 & 5.674 & .023 & .139 \\
\hline & Period & 84.547 & 1 & 84.547 & .726 & .400 & .020 \\
\hline & Group * Period & 10.370 & 1 & 10.370 & .089 & .767 & .003 \\
\hline & Error & 4074.905 & 35 & 116.426 & & & \\
\hline & Total & 6610768.070 & 39 & & & & \\
\hline & Corrected Total & 4834.972 & 38 & & & & \\
\hline \multirow[t]{8}{*}{ Social Studies } & Correct Model & $269.639^{d}$ & 3 & 89.880 & .637 & .596 & .053 \\
\hline & Intercept & 6477134.360 & 1 & 6477134.360 & 45932.013 & .000 & .999 \\
\hline & Group & 210.749 & 1 & 210.749 & 1.495 & .230 & .042 \\
\hline & Period & 9.478 & 1 & 9.478 & .067 & .797 & .002 \\
\hline & Group * Period & 58.634 & 1 & 58.634 & .416 & .523 & .012 \\
\hline & Error & 4794.533 & 34 & 141.016 & & & \\
\hline & Total & 6834686.700 & 38 & & & & \\
\hline & Corrected Total & 5064.173 & 37 & & & & \\
\hline \multirow[t]{8}{*}{ Writing } & Correct Model & $545.384^{\mathrm{e}}$ & 3 & 181.795 & 1.224 & .316 & .097 \\
\hline & Intercept & 6348167.280 & 1 & 6348167.280 & 42736.862 & .000 & .999 \\
\hline & Group & 483.600 & 1 & 483.600 & 3.256 & .080 & .087 \\
\hline & Period & 61.381 & 1 & 61.381 & .413 & .525 & .012 \\
\hline & Group * Period & 16.252 & 1 & 16.252 & .109 & .743 & .003 \\
\hline & Error & 5050.387 & 34 & 148.541 & & & \\
\hline & Total & 6873086.280 & 38 & & & & \\
\hline & Corrected Total & 5595.771 & 37 & & & & \\
\hline
\end{tabular}

a. $\mathrm{R}$ Squared $=.046$ (Adjusted R Squared $=-.035$ )

b. $\mathrm{R}$ Squared $=.186$ (Adjusted R Squared $=.116)$

c. $R$ Squared $=.157$ (Adjusted R Squared $=.085$ )

d. $R$ Squared $=.053$ (Adjusted R Squared $=-.030$ )

e. $\mathrm{R}$ Squared $=.142($ Adjusted $R$ Squared $=.103)$ 
SPSS Output for ANOVA - Performance by Time Cluster (RACE)

Tests of Between-Subjects Effects

Dependent Variable: White SS

\begin{tabular}{|c|c|c|c|c|c|c|c|}
\hline Time & Source & $\begin{array}{l}\text { Type III Sum } \\
\text { of Squares }\end{array}$ & df & $\begin{array}{l}\text { Mean } \\
\text { Square }\end{array}$ & $\mathrm{F}$ & Sig. & $\begin{array}{l}\text { Partial } \\
\text { Eta } \\
\text { Squared }\end{array}$ \\
\hline \multirow[t]{8}{*}{1} & Corrected Model & $374.659^{a}$ & 3 & 124.886 & 1.484 & .218 & .007 \\
\hline & Intercept & 7.170E7 & 1 & 7.170E7 & 851955.765 & .000 & .999 \\
\hline & Group & 359.368 & 1 & 359.368 & 4.270 & .039 & .007 \\
\hline & Period & 10.922 & 1 & 10.922 & .130 & .719 & .000 \\
\hline & Group * Period & 94.129 & 1 & 94.129 & 1.119 & .291 & .002 \\
\hline & Error & 50155.662 & 596 & 84.154 & & & \\
\hline & Total & 1.120E8 & 600 & & & & \\
\hline & Corrected Total & 50530.321 & 599 & & & & \\
\hline \multirow[t]{8}{*}{2} & Corrected Model & $1596.349^{b}$ & 3 & 532.116 & 5.359 & .001 & .037 \\
\hline & Intercept & 7.014E7 & 1 & 7.014E7 & 706408.762 & .000 & .999 \\
\hline & Group & 1267.394 & 1 & 1267.394 & 12.765 & .000 & .030 \\
\hline & Period & 168.126 & 1 & 168.126 & 1.693 & .194 & .004 \\
\hline & Group * Period & .008 & 1 & .008 & .000 & .993 & .000 \\
\hline & Error & 41303.104 & 416 & 99.286 & & & \\
\hline & Total & 7.887E7 & 420 & & & & \\
\hline & Corrected Total & 42899.453 & 419 & & & & \\
\hline \multirow[t]{8}{*}{3} & Corrected Model & $492.544^{c}$ & 3 & 164.181 & 2.810 & .042 & .058 \\
\hline & Intercept & $2.550 \mathrm{E} 7$ & 1 & $2.550 \mathrm{E} 7$ & 436582.965 & .000 & 1.000 \\
\hline & Group & 21.195 & 1 & 21.195 & .363 & .548 & .003 \\
\hline & Period & 460.429 & 1 & 460.429 & 7.882 & .006 & .055 \\
\hline & Group * Period & 6.828 & 1 & 6.828 & .117 & .733 & .001 \\
\hline & Error & 7944.846 & 136 & 58.418 & & & \\
\hline & Total & 2.601E7 & 140 & & & & \\
\hline & Corrected Total & 8437.390 & 139 & & & & \\
\hline \multirow[t]{8}{*}{4} & Corrected Model & $530.637^{d}$ & 3 & 176.879 & 2.433 & .066 & .030 \\
\hline & Intercept & 4.566E7 & 1 & 4.566E7 & 628062.096 & .000 & 1.000 \\
\hline & Group & 133.057 & 1 & 133.057 & 1.830 & .177 & .008 \\
\hline & Period & 126.005 & 1 & 126.005 & 1.733 & .189 & .007 \\
\hline & Group * Period & 271.575 & 1 & 271.575 & 3.735 & .054 & .016 \\
\hline & Error & 17158.378 & 236 & 72.705 & & & \\
\hline & Total & 4.568E7 & 240 & & & & \\
\hline & Corrected Total & 17689.015 & 239 & & & & \\
\hline
\end{tabular}

a. R Squared $=.007$ (Adjusted R Squared $=.002$ )

b. $\mathrm{R}$ Squared $=.037$ (Adjusted R Squared $=.030$ )

c. $R$ Squared $=.058$ (Adjusted R Squared $=.038$ )

d. R Squared $=.030$ (Adjusted R Squared $=.018$ ) 
Dependent Variable: Black SS

\section{Tests of Between-Subjects Effects}

\begin{tabular}{|c|c|c|c|c|c|c|c|}
\hline Time & Source & $\begin{array}{l}\text { Type III Sum } \\
\text { of Squares }\end{array}$ & df & Mean Square & $\mathrm{F}$ & Sig. & $\begin{array}{c}\text { Partial Eta } \\
\text { Squared }\end{array}$ \\
\hline \multirow[t]{8}{*}{1} & Corrected Model & $182.090^{\mathrm{a}}$ & 2 & 91.045 & 1.017 & .373 & .060 \\
\hline & Intercept & 3943270.578 & 1 & 3943270.578 & 44043.857 & .000 & .999 \\
\hline & Group & 3.468 & 1 & 3.468 & .039 & .845 & .001 \\
\hline & Period & 119.004 & 1 & 119.004 & 1.329 & .257 & .040 \\
\hline & Group * Period & .000 & 0 & & & & .000 \\
\hline & Error & 2864.977 & 32 & 89.531 & & & \\
\hline & Total & 6046951.710 & 35 & & & & \\
\hline & Corrected Total & 3047.067 & 34 & & & & \\
\hline \multirow[t]{8}{*}{2} & Corrected Model & $561.075^{b}$ & 3 & 187.025 & 1.363 & .262 & .060 \\
\hline & Intercept & 1.065E7 & 1 & $1.065 \mathrm{E} 7$ & 77654.905 & .000 & .999 \\
\hline & Group & 95.370 & 1 & 95.370 & .695 & .408 & .011 \\
\hline & Period & 204.417 & 1 & 204.417 & 1.490 & .227 & .023 \\
\hline & Group * Period & 198.031 & 1 & 198.031 & 1.443 & .234 & .022 \\
\hline & Error & 8780.033 & 64 & 137.188 & & & \\
\hline & Total & 1.181E7 & 68 & & & & \\
\hline & Corrected Total & 9341.108 & 67 & & & & \\
\hline \multirow[t]{8}{*}{4} & Corrected Model & $4728.349^{C}$ & 3 & 1576.116 & 16.098 & .000 & .360 \\
\hline & Intercept & 1.629E7 & 1 & 1.629E7 & 166412.42 & .000 & .999 \\
\hline & Group & 3903.450 & 1 & 3903.450 & 39.869 & .000 & .317 \\
\hline & Period & 760.890 & 1 & 760.890 & 7.772 & .007 & .083 \\
\hline & Group * Period & 23.874 & 1 & 23.874 & .244 & .623 & .003 \\
\hline & Error & 8420.018 & 86 & 97.907 & & & \\
\hline & Total & 1.645E7 & 90 & & & & \\
\hline & Corrected Total & 13148.367 & 89 & & & & \\
\hline
\end{tabular}

a. R Squared $=.060$ (Adjusted R Squared $=.001)$

b. $\mathrm{R}$ Squared $=.060$ (Adjusted R Squared $=.016)$

c. $\mathrm{R}$ Squared $=.360$ (Adjusted R Squared $=.337$ ) 
Tests of Between-Subjects Effects

Dependent Variable: Other (Combined)

\begin{tabular}{|c|c|c|c|c|c|c|c|}
\hline Time & Source & $\begin{array}{l}\text { Type III Sum } \\
\text { of Squares }\end{array}$ & df & $\begin{array}{l}\text { Mean } \\
\text { Square }\end{array}$ & $\mathrm{F}$ & Sig. & $\begin{array}{l}\text { Partial Eta } \\
\text { Squared }\end{array}$ \\
\hline \multirow[t]{8}{*}{1} & Corrected Model & $1001.786^{a}$ & 3 & 333.929 & 4.336 & .007 & .122 \\
\hline & Intercept & 1.105E7 & 1 & 1.105E7 & 143511.124 & .000 & .999 \\
\hline & Group & 222.120 & 1 & 222.120 & 2.884 & .093 & .030 \\
\hline & Period & 37.601 & 1 & 37.601 & .488 & .486 & .005 \\
\hline & Group * Period & 167.894 & 1 & 167.894 & 2.180 & .143 & .023 \\
\hline & Error & 7239.168 & 94 & 77.012 & & & \\
\hline & Total & $1.726 \mathrm{E} 7$ & 98 & & & & \\
\hline & Corrected Total & 8240.954 & 97 & & & & \\
\hline \multirow[t]{8}{*}{2} & Corrected Model & $1795.173^{b}$ & 3 & 598.391 & 6.209 & .001 & .134 \\
\hline & Intercept & 2.057E7 & 1 & 2.057E7 & 213384.259 & .000 & .999 \\
\hline & Group & 951.337 & 1 & 951.337 & 9.871 & .002 & .076 \\
\hline & Period & 107.273 & 1 & 107.273 & 1.113 & .294 & .009 \\
\hline & Group * Period & 291.695 & 1 & 291.695 & 3.027 & .084 & .025 \\
\hline & Error & 11565.454 & 120 & 96.379 & & & \\
\hline & Total & 2.256E7 & 124 & & & & \\
\hline & Corrected Total & 13360.627 & 123 & & & & \\
\hline \multirow[t]{8}{*}{3} & Corrected Model & $71.148^{C}$ & 1 & 71.148 & .975 & .341 & .070 \\
\hline & Intercept & 2405047.788 & 1 & 2405047.788 & 32956.417 & .000 & 1.000 \\
\hline & Group & .000 & 0 & & & & .000 \\
\hline & Period & 71.148 & 1 & 71.148 & .975 & .341 & .070 \\
\hline & Group * Period & .000 & 0 & & & & .000 \\
\hline & Error & 948.696 & 13 & 72.977 & & & \\
\hline & Total & 2716518.300 & 15 & & & & \\
\hline & Corrected Total & 1019.844 & 14 & & & & \\
\hline \multirow[t]{8}{*}{4} & Corrected Model & $2699.765^{d}$ & 3 & 899.922 & 10.528 & .000 & .230 \\
\hline & Intercept & $1.834 \mathrm{E} 7$ & 1 & 1.834E7 & 214575.242 & .000 & 1.000 \\
\hline & Group & 1537.339 & 1 & 1537.339 & 17.985 & .000 & .145 \\
\hline & Period & 583.479 & 1 & 583.479 & 6.826 & .010 & .060 \\
\hline & Group * Period & 829.221 & 1 & 829.221 & 9.701 & .002 & .084 \\
\hline & Error & 9060.880 & 106 & 85.480 & & & \\
\hline & Total & 2.008E7 & 110 & & & & \\
\hline & Corrected Total & 11760.646 & 109 & & & & \\
\hline
\end{tabular}

a. R Squared $=.122$ (Adjusted R Squared $=.094$ )

b. R Squared $=.134$ (Adjusted $R$ Squared $=.113$ )

c. $\mathrm{R}$ Squared $=.070$ (Adjusted $\mathrm{R}$ Squared $=-.002$ )

d. R Squared $=.230$ (Adjusted R Squared $=.208$ ) 
APPENDIX L 
SPSS Output for ANOVA - Overall performance in all content areas (DISABILITY

\section{STATUS)}

Dependent Variable: IEP SS

\section{Tests of Between-Subjects Effects}

\begin{tabular}{|l|r|r|r|r|r|r|}
\hline Source & $\begin{array}{c}\text { Type III Sum of } \\
\text { Squares }\end{array}$ & df & Mean Square & \multicolumn{1}{|c|}{ F } & Sig. & $\begin{array}{c}\text { Partial Eta } \\
\text { Squared }\end{array}$ \\
\hline Corrected Model & $1287.799^{\mathrm{a}}$ & 3 & 429.266 & 5.293 & .001 & .022 \\
Intercept & $9.211 \mathrm{E7}$ & 1 & $9.211 \mathrm{E} 7$ & 1135801.858 & .000 & .999 \\
Group & 301.222 & 1 & 301.222 & 3.714 & .054 & .005 \\
Period & 676.185 & 1 & 676.185 & 8.338 & .004 & .011 \\
Group * Period & 74.593 & 1 & 74.593 & .920 & .338 & .001 \\
Error & 58471.385 & 721 & 81.098 & & & \\
Total & $1.154 \mathrm{E} 8$ & 725 & & & & \\
Corrected Total & 59759.184 & 724 & & & & \\
\hline
\end{tabular}

a. $\mathrm{R}$ Squared $=.022$ (Adjusted R Squared $=.017$ ) 
SPSS Output for ANOVA - Performance by Content Area (DISABILITY STATUS)

Tests of Between-Subjects Effects

Dependent Variable: IEP SS

\begin{tabular}{|c|c|c|c|c|c|c|c|}
\hline Content & Source & $\begin{array}{l}\text { Type III Sum } \\
\text { of Squares }\end{array}$ & df & Mean Square & $\mathrm{F}$ & Sig. & $\begin{array}{l}\text { Partial } \\
\text { Eta } \\
\text { Squared }\end{array}$ \\
\hline \multirow[t]{8}{*}{ Math } & Correct Model & $295.998^{a}$ & 3 & 98.666 & 1.310 & .274 & .027 \\
\hline & Intercept & 1.857E7 & 1 & 1.857E7 & 246546.878 & .000 & .999 \\
\hline & Group & 24.162 & 1 & 24.162 & .321 & .572 & .002 \\
\hline & Period & 119.774 & 1 & 119.774 & 1.590 & .209 & .011 \\
\hline & Group * Period & 83.786 & 1 & 83.786 & 1.112 & .293 & .008 \\
\hline & Error & 10695.165 & 142 & 75.318 & & & \\
\hline & Total & 2.336E7 & 146 & & & & \\
\hline & Corrected Total & 10991.163 & 145 & & & & \\
\hline \multirow[t]{8}{*}{ Reading } & Correct Model & $269.938^{b}$ & 3 & 89.979 & 1.968 & .122 & .040 \\
\hline & Intercept & $1.862 \mathrm{E} 7$ & 1 & $1.862 \mathrm{E} 7$ & 407333.786 & .000 & 1.000 \\
\hline & Group & 8.197 & 1 & 8.197 & .179 & .673 & .001 \\
\hline & Period & 259.437 & 1 & 259.437 & 5.674 & .019 & .039 \\
\hline & Group * Period & .243 & 1 & .243 & .005 & .942 & .000 \\
\hline & Error & 6446.504 & 141 & 45.720 & & & \\
\hline & Total & 2.329E7 & 145 & & & & \\
\hline & Corrected Total & 6716.442 & 144 & & & & \\
\hline \multirow[t]{8}{*}{ Science } & Correct Model & $305.413^{c}$ & 3 & 101.804 & 1.443 & .233 & .030 \\
\hline & Intercept & 1.794E7 & 1 & 1.794E7 & 254231.789 & .000 & .999 \\
\hline & Group & 96.762 & 1 & 96.762 & 1.371 & .244 & .010 \\
\hline & Period & 115.365 & 1 & 115.365 & 1.635 & .203 & .011 \\
\hline & Group * Period & 20.744 & 1 & 20.744 & .294 & .589 & .002 \\
\hline & Error & 9948.522 & 141 & 70.557 & & & \\
\hline & Total & $2.248 \mathrm{E} 7$ & 145 & & & & \\
\hline & Corrected Total & 10253.936 & 144 & & & & \\
\hline \multirow[t]{8}{*}{ Social Studies } & Correct Model & $776.903^{\mathrm{d}}$ & 3 & 258.968 & 2.397 & .071 & .049 \\
\hline & Intercept & $1.836 \mathrm{E} 7$ & 1 & 1.836E7 & 169952.415 & .000 & .999 \\
\hline & Group & 140.872 & 1 & 140.872 & 1.304 & .255 & .009 \\
\hline & Period & 602.448 & 1 & 602.448 & 5.576 & .020 & .038 \\
\hline & Group * Period & .016 & 1 & .016 & .000 & .990 & .000 \\
\hline & Error & 15234.747 & 141 & 108.048 & & & \\
\hline & Total & 2.296E7 & 145 & & & & \\
\hline & Corrected Total & 16011.650 & 144 & & & & \\
\hline \multirow[t]{8}{*}{ Writing } & Correct Model & $260.978^{\mathrm{e}}$ & 3 & 86.993 & 1.328 & .268 & .028 \\
\hline & Intercept & $1.862 \mathrm{E} 7$ & 1 & $1.862 \mathrm{E} 7$ & 284212.843 & .000 & 1.000 \\
\hline & Group & 95.333 & 1 & 95.333 & 1.455 & .230 & .010 \\
\hline & Period & 18.003 & 1 & 18.003 & .275 & .601 & .002 \\
\hline & Group * Period & 41.246 & 1 & 41.246 & .630 & .429 & .004 \\
\hline & Error & 9172.219 & 140 & 65.516 & & & \\
\hline & Total & 2.331E7 & 144 & & & & \\
\hline & Corrected Total & 9433.197 & 143 & & & & \\
\hline
\end{tabular}

a. R Squared $=.027$ (Adjusted R Squared $=.006$ )

b. $\mathrm{R}$ Squared $=.040$ (Adjusted $\mathrm{R}$ Squared $=.020)$

c. $R$ Squared $=.030$ (Adjusted $R$ Squared $=.009$ )

d. $R$ Squared $=.049$ (Adjusted R Squared $=.028$ )

e. $\mathrm{R}$ Squared $=.028$ (Adjusted R Squared $=.007$ ) 
SPSS Output for ANOVA - Performance by Time Cluster (DISABILITY STATUS)

Tests of Between-Subjects Effects

\begin{tabular}{|c|c|c|c|c|c|c|c|}
\hline Time & Source & Type III Sum of Squares & $\mathrm{df}$ & Mean Square & $F$ & Sig. & $\begin{array}{l}\text { Partial Eta } \\
\text { Squared }\end{array}$ \\
\hline \multirow[t]{8}{*}{1} & Corrected Model & $302.356^{a}$ & 3 & 100.785 & 1.390 & .246 & .012 \\
\hline & Intercept & $3.116 \mathrm{E} 7$ & 1 & $3.116 \mathrm{E} 7$ & 429749.338 & .000 & .999 \\
\hline & Group & 119.494 & 1 & 119.494 & 1.648 & .200 & .005 \\
\hline & Period & 1.288 & 1 & 1.288 & .018 & .894 & .000 \\
\hline & Group * Period & 300.891 & 1 & 300.891 & 4.150 & .042 & .012 \\
\hline & Error & 24145.740 & 333 & 72.510 & & & \\
\hline & Total & 5.327E7 & 337 & & & & \\
\hline & Corrected Total & 24448.096 & 336 & & & & \\
\hline \multirow[t]{8}{*}{2} & Corrected Model & $160.119^{C}$ & 3 & 53.373 & .616 & .605 & .010 \\
\hline & Intercept & 2.475E7 & 1 & 2.475E7 & 285636.164 & .000 & .999 \\
\hline & Group & 26.196 & 1 & 26.196 & .302 & .583 & .002 \\
\hline & Period & 128.945 & 1 & 128.945 & 1.488 & .224 & .008 \\
\hline & Group * Period & .416 & 1 & .416 & .005 & .945 & .000 \\
\hline & Error & 16378.276 & 189 & 86.658 & & & \\
\hline & Total & 3.065E7 & 193 & & & & \\
\hline & Corrected Total & 16538.395 & 192 & & & & \\
\hline \multirow[t]{8}{*}{3} & Corrected Model & $1464.617^{\mathrm{d}}$ & 3 & 488.206 & 17.592 & .000 & .444 \\
\hline & Intercept & 1.077E7 & 1 & 1.077E7 & 388119.872 & .000 & 1.000 \\
\hline & Group & 1034.520 & 1 & 1034.520 & 37.278 & .000 & .361 \\
\hline & Period & 419.760 & 1 & 419.760 & 15.126 & .000 & .186 \\
\hline & Group * Period & 60.482 & 1 & 60.482 & 2.179 & .145 & .032 \\
\hline & Error & 1831.611 & 66 & 27.752 & & & \\
\hline & Total & $1.098 \mathrm{E} 7$ & 70 & & & & \\
\hline & Corrected Total & 3296.229 & 69 & & & & \\
\hline \multirow[t]{8}{*}{4} & Corrected Model & $1527.476^{\mathrm{e}}$ & 3 & 509.159 & 7.570 & .000 & .158 \\
\hline & Intercept & 1.989E7 & 1 & 1.989E7 & 295711.389 & .000 & 1.000 \\
\hline & Group & 947.301 & 1 & 947.301 & 14.084 & .000 & .104 \\
\hline & Period & 48.429 & 1 & 48.429 & .720 & .398 & .006 \\
\hline & Group * Period & 404.753 & 1 & 404.753 & 6.018 & .016 & .047 \\
\hline & Error & 8138.652 & 121 & 67.262 & & & \\
\hline & Total & 2.050E7 & 125 & & & & \\
\hline & Corrected Total & 9666.128 & 124 & & & & \\
\hline
\end{tabular}

a. $\mathrm{R}$ Squared $=.012$ (Adjusted $\mathrm{R}$ Squared $=.003$ )

b. Computed using alpha $=.05$

c. $R$ Squared $=.010$ (Adjusted R Squared $=-.006$ )

d. $\mathrm{R}$ Squared $=.444$ (Adjusted R Squared $=.419)$

e. $\mathrm{R}$ Squared $=.158($ Adjusted $R$ Squared $=.137)$ 
APPENDIX M 
SPSS Output for ANOVA - Overall performance in all content areas (ECONOMIC

\section{STATUS)}

Tests of Between-Subjects Effects

Dependent Variable:ED \%prf

\begin{tabular}{|l|r|r|r|r|r|r|}
\hline Source & $\begin{array}{c}\text { Type III Sum of } \\
\text { Squares }\end{array}$ & df & Mean Square & F & Sig. & $\begin{array}{c}\text { Partial Eta } \\
\text { Squared }\end{array}$ \\
\hline Corrected & $.174^{\mathrm{a}}$ & 3 & .058 & 5.178 & .001 & .015 \\
Model & 286.475 & 1 & 286.475 & 25543.269 & .000 & .962 \\
Intercept & .010 & 1 & .010 & .865 & .353 & .001 \\
Group & .091 & 1 & .091 & 8.133 & .004 & .008 \\
Period & .000 & 1 & .000 & .029 & .865 & .000 \\
interaction & 11.283 & 1006 & .011 & & & \\
Error & 654.851 & 1010 & & & & \\
Total & 11.457 & 1009 & & & & \\
Corrected Total & 1009 & & & \\
\hline
\end{tabular}
a. R Squared $=.015$ (Adjusted
$\mathrm{R}$ Squared $=$.012)
b. Computed using alpha $=.05$ 
SPSS Output for ANOVA - Performance by Content Area (ECONOMIC STATUS)

Tests of Between-Subjects Effects

Dependent Variable:ED \%prf

\begin{tabular}{|c|c|c|c|c|c|c|c|}
\hline Content & Source & $\begin{array}{l}\text { Type III Sum } \\
\text { of Squares }\end{array}$ & df & $\begin{array}{l}\text { Mean } \\
\text { Square }\end{array}$ & $\mathrm{F}$ & Sig. & $\begin{array}{c}\text { Partial } \\
\text { Eta } \\
\text { Squared }\end{array}$ \\
\hline \multirow[t]{8}{*}{ Math } & Corrected Model & $.057^{\mathrm{a}}$ & 3 & .019 & 1.965 & .120 & .029 \\
\hline & Intercept & 58.034 & 1 & 58.034 & 5995.393 & .000 & .968 \\
\hline & Group & .025 & 1 & .025 & 2.620 & .107 & .013 \\
\hline & Period & .017 & 1 & .017 & 1.768 & .185 & .009 \\
\hline & interaction & .001 & 1 & .001 & .071 & .790 & .000 \\
\hline & Error & 1.917 & 198 & .010 & & & \\
\hline & Total & 132.785 & 202 & & & & \\
\hline & Corrected Total & 1.974 & 201 & & & & \\
\hline \multirow[t]{8}{*}{ Reading } & Corrected Model & $.050^{\mathrm{C}}$ & 3 & .017 & 2.236 & .085 & .033 \\
\hline & Intercept & 61.850 & 1 & 61.850 & 8221.827 & .000 & .976 \\
\hline & Group & 1.309E-6 & 1 & $1.309 \mathrm{E}-6$ & .000 & .989 & .000 \\
\hline & Period & .034 & 1 & .034 & 4.572 & .034 & .023 \\
\hline & interaction & .001 & 1 & .001 & .194 & .660 & .001 \\
\hline & Error & 1.489 & 198 & .008 & & & \\
\hline & Total & 141.010 & 202 & & & & \\
\hline & Corrected Total & 1.540 & 201 & & & & \\
\hline \multirow[t]{8}{*}{ Science } & Corrected Model & $.055^{\mathrm{d}}$ & 3 & .018 & 1.429 & .235 & .021 \\
\hline & Intercept & 48.747 & 1 & 48.747 & 3801.624 & .000 & .950 \\
\hline & Group & .006 & 1 & .006 & .464 & .496 & .002 \\
\hline & Period & .032 & 1 & .032 & 2.476 & .117 & .012 \\
\hline & interaction & .001 & 1 & .001 & .064 & .800 & .000 \\
\hline & Error & 2.539 & 198 & .013 & & & \\
\hline & Total & 112.094 & 202 & & & & \\
\hline & Corrected Total & 2.594 & 201 & & & & \\
\hline \multirow{8}{*}{$\begin{array}{l}\text { Social } \\
\text { Studies }\end{array}$} & Corrected Model & $.075^{\mathrm{e}}$ & 3 & .025 & 2.516 & .060 & .037 \\
\hline & Intercept & 53.967 & 1 & 53.967 & 5446.018 & .000 & .965 \\
\hline & Group & .005 & 1 & .005 & .461 & .498 & .002 \\
\hline & Period & .023 & 1 & .023 & 2.316 & .130 & .012 \\
\hline & interaction & .003 & 1 & .003 & .335 & .563 & .002 \\
\hline & Error & 1.962 & 198 & .010 & & & \\
\hline & Total & 121.094 & 202 & & & & \\
\hline & Corrected Total & 2.037 & 201 & & & & \\
\hline \multirow[t]{8}{*}{ Writing } & Corrected Model & $.005^{\dagger}$ & 3 & .002 & .216 & .885 & .003 \\
\hline & Intercept & 64.580 & 1 & 64.580 & 8220.499 & .000 & .976 \\
\hline & Group & .003 & 1 & .003 & .352 & .554 & .002 \\
\hline & Period & .001 & 1 & .001 & .110 & .740 & .001 \\
\hline & interaction & 2.384E-5 & 1 & 2.384E-5 & .003 & .956 & .000 \\
\hline & Error & 1.555 & 198 & .008 & & & \\
\hline & Total & 147.868 & 202 & & & & \\
\hline & Corrected Total & 1.561 & 201 & & & & \\
\hline
\end{tabular}

a. R Squared $=.029$ (Adjusted R Squared $=.014$ )

b. Computed using alpha $=.05$

c. R Squared $=.033$ (Adjusted R Squared $=.018$ )

d. $\mathrm{R}$ Squared $=.021$ (Adjusted $\mathrm{R}$ Squared $=.006$ )

e. $R$ Squared $=.037$ (Adjusted $R$ Squared $=.022$ )

f. $R$ Squared $=.003$ (Adjusted $R$ Squared $=-.012$ ) 
SPSS Output for ANOVA - Performance by Time Cluster (ECONOMIC STATUS)

Tests of Between-Subjects Effects

Dependent Variable: ED \%prf

\begin{tabular}{|c|c|c|c|c|c|c|c|}
\hline Time & Source & $\begin{array}{l}\text { Type III } \\
\text { Sum of } \\
\text { Squares }\end{array}$ & df & $\begin{array}{l}\text { Mean } \\
\text { Square }\end{array}$ & $F$ & Sig. & $\begin{array}{l}\text { Partial } \\
\text { Eta } \\
\text { Squared }\end{array}$ \\
\hline \multirow[t]{8}{*}{1} & Corrected Model & $.016^{\mathrm{a}}$ & 3 & .005 & .533 & .660 & .004 \\
\hline & Intercept & 92.831 & 1 & 92.831 & 9476.872 & .000 & .956 \\
\hline & Group & .001 & 1 & .001 & .056 & .813 & .000 \\
\hline & Period & .012 & 1 & .012 & 1.195 & .275 & .003 \\
\hline & interaction & .013 & 1 & .013 & 1.314 & .252 & .003 \\
\hline & Error & 4.320 & 441 & .010 & & & \\
\hline & Total & 292.087 & 445 & & & & \\
\hline & Corrected Total & 4.335 & 444 & & & & \\
\hline \multirow[t]{8}{*}{2} & Corrected Model & $.140^{\mathrm{C}}$ & 3 & .047 & 3.336 & .020 & .034 \\
\hline & Intercept & 78.287 & 1 & 78.287 & 5585.276 & .000 & .952 \\
\hline & Group & .003 & 1 & .003 & .181 & .671 & .001 \\
\hline & Period & .038 & 1 & .038 & 2.727 & .100 & .010 \\
\hline & interaction & .007 & 1 & .007 & .464 & .496 & .002 \\
\hline & Error & 3.939 & 281 & .014 & & & \\
\hline & Total & 178.076 & 285 & & & & \\
\hline & Corrected Total & 4.079 & 284 & & & & \\
\hline \multirow[t]{8}{*}{3} & Corrected Model & $.110^{\mathrm{d}}$ & 3 & .037 & 3.929 & .010 & .092 \\
\hline & Intercept & 42.171 & 1 & 42.171 & 4532.534 & .000 & .975 \\
\hline & Group & .002 & 1 & .002 & .162 & .688 & .001 \\
\hline & Period & .025 & 1 & .025 & 2.733 & .101 & .023 \\
\hline & interaction & .010 & 1 & .010 & 1.059 & .305 & .009 \\
\hline & Error & 1.079 & 116 & .009 & & & \\
\hline & Total & 77.827 & 120 & & & & \\
\hline & Corrected Total & 1.189 & 119 & & & & \\
\hline \multirow[t]{8}{*}{4} & Corrected Model & $.071^{\mathrm{e}}$ & 3 & .024 & 2.222 & .088 & .041 \\
\hline & Intercept & 51.015 & 1 & 51.015 & 4790.670 & .000 & .968 \\
\hline & Group & .037 & 1 & .037 & 3.517 & .063 & .022 \\
\hline & Period & .056 & 1 & .056 & 5.241 & .023 & .033 \\
\hline & interaction & .023 & 1 & .023 & 2.177 & .142 & .014 \\
\hline & Error & 1.661 & 156 & .011 & & & \\
\hline & Total & 106.861 & 160 & & & & \\
\hline & Corrected Total & 1.732 & 159 & & & & \\
\hline
\end{tabular}

a. R Squared $=.004$ (Adjusted R Squared $=-.003$ )

b. Computed using alpha $=.05$

c. R Squared $=.034$ (Adjusted R Squared $=.024$ )

d. $R$ Squared $=.092$ (Adjusted R Squared $=.069$ )

e. $\mathrm{R}$ Squared $=.041$ (Adjusted R Squared $=.023$ ) 
APPENDIX N 


\section{Descriptive Statistics}

Dependent Variable:Total SS
\begin{tabular}{|ll|r|r|r|}
\hline Device & Period & Mean & $\begin{array}{c}\text { Std. } \\
\text { Deviation }\end{array}$ & \multicolumn{1}{c|}{$\mathrm{N}$} \\
\hline Laptop & PRE Treatment & 431.452 & 8.5136 & 180 \\
& POST Treatment & 432.721 & 7.2120 & 125 \\
& Total & 431.972 & 8.0178 & 305 \\
\hline Netbook & PRE Treatment & 430.778 & 8.3719 & 140 \\
& POST Treatment & 432.424 & 7.7037 & 45 \\
& Total & 431.178 & 8.2244 & 185 \\
\hline iPad & PRE Treatment & 432.392 & 9.9939 & 160 \\
& POST Treatment & 432.654 & 9.2878 & 50 \\
& Total & 432.454 & 9.8092 & 210 \\
\hline Total & PRE Treatment & 431.569 & 8.9996 & 480 \\
& POST Treatment & 432.645 & 7.7903 & 220 \\
& Total & 431.907 & 8.6467 & 700 \\
& & & & \\
\hline
\end{tabular}


Descriptive Statistics

Dependent Variable:Total SS

\begin{tabular}{|c|c|c|c|c|c|}
\hline Content & Device & Period & Mean & $\begin{array}{c}\text { Std. } \\
\text { Deviation }\end{array}$ & $\mathrm{N}$ \\
\hline \multirow[t]{9}{*}{ Math } & \multirow[t]{3}{*}{ Laptop } & PRE Treatment & 435.925 & 8.2029 & 36 \\
\hline & & POST Treatment & 438.336 & 6.2978 & 25 \\
\hline & & Total & 436.913 & 7.5197 & 61 \\
\hline & \multirow[t]{3}{*}{ Netbook } & PRE Treatment & 438.989 & 8.2641 & 28 \\
\hline & & POST Treatment & 442.522 & 8.5888 & 9 \\
\hline & & Total & 439.849 & 8.3652 & 37 \\
\hline & \multirow[t]{3}{*}{ iPad } & PRE Treatment & 438.522 & 10.3631 & 32 \\
\hline & & POST Treatment & 439.890 & 9.9966 & 10 \\
\hline & & Total & 438.848 & 10.1728 & 42 \\
\hline \multirow[t]{9}{*}{ Reading } & \multirow[t]{3}{*}{ Laptop } & PRE Treatment & 429.506 & 7.0309 & 36 \\
\hline & & POST Treatment & 431.888 & 4.8971 & 25 \\
\hline & & Total & 430.482 & 6.3107 & 61 \\
\hline & \multirow[t]{3}{*}{ Netbook } & PRE Treatment & 427.975 & 5.2697 & 28 \\
\hline & & POST Treatment & 429.444 & 1.9856 & 9 \\
\hline & & Total & 428.332 & 4.7023 & 37 \\
\hline & \multirow[t]{3}{*}{ iPad } & PRE Treatment & 430.144 & 7.6318 & 32 \\
\hline & & POST Treatment & 430.820 & 5.0148 & 10 \\
\hline & & Total & 430.305 & 7.0459 & 42 \\
\hline \multirow[t]{9}{*}{ Science } & \multirow[t]{3}{*}{ Laptop } & PRE Treatment & 425.839 & 6.2492 & 36 \\
\hline & & POST Treatment & 427.212 & 3.8178 & 25 \\
\hline & & Total & 426.402 & 5.3921 & 61 \\
\hline & \multirow[t]{3}{*}{ Netbook } & PRE Treatment & 425.911 & 7.1546 & 28 \\
\hline & & POST Treatment & 428.111 & 5.0839 & 9 \\
\hline & & Total & 426.446 & 6.7120 & 37 \\
\hline & \multirow[t]{3}{*}{ iPad } & PRE Treatment & 427.084 & 8.6105 & 32 \\
\hline & & POST Treatment & 429.080 & 8.0294 & 10 \\
\hline & & Total & 427.560 & 8.4232 & 42 \\
\hline \multirow{9}{*}{$\begin{array}{c}\text { Social } \\
\text { Studies }\end{array}$} & \multirow[t]{3}{*}{ Laptop } & PRE Treatment & 432.731 & 7.5925 & 36 \\
\hline & & POST Treatment & 436.800 & 7.4306 & 25 \\
\hline & & Total & 434.398 & 7.7320 & 61 \\
\hline & \multirow[t]{3}{*}{ Netbook } & PRE Treatment & 432.518 & 7.6049 & 28 \\
\hline & & POST Treatment & 434.722 & 6.3976 & 9 \\
\hline & & Total & 433.054 & 7.3069 & 37 \\
\hline & \multirow[t]{3}{*}{ iPad } & PRE Treatment & 436.141 & 9.8236 & 32 \\
\hline & & POST Treatment & 435.530 & 10.9901 & 10 \\
\hline & & Total & 435.995 & 9.9774 & 42 \\
\hline \multirow[t]{9}{*}{ Writing } & \multirow[t]{3}{*}{ Laptop } & PRE Treatment & 433.261 & 9.7644 & 36 \\
\hline & & POST Treatment & 429.368 & 6.4095 & 25 \\
\hline & & Total & 431.666 & 8.7050 & 61 \\
\hline & \multirow[t]{3}{*}{ Netbook } & PRE Treatment & 428.496 & 6.6752 & 28 \\
\hline & & POST Treatment & 427.322 & 1.0317 & 9 \\
\hline & & Total & 428.211 & 5.8238 & 37 \\
\hline & \multirow[t]{3}{*}{ iPad } & PRE Treatment & 430.069 & 9.1012 & 32 \\
\hline & & POST Treatment & 427.950 & 7.0309 & 10 \\
\hline & & Total & 429.564 & 8.6206 & 42 \\
\hline
\end{tabular}


SPSS Output for ANOVA - Overall performance in all content areas (DEVICE)

Tests of Between-Subjects Effects

Dependent Variable:Total SS

\begin{tabular}{|l|r|r|r|r|r|r|}
\hline Source & $\begin{array}{r}\text { Type III Sum of } \\
\text { Squares }\end{array}$ & df & Mean Square & F & Sig. & $\begin{array}{c}\text { Partial Eta } \\
\text { Squared }\end{array}$ \\
\hline Correct Model & $376.073^{\mathrm{a}}$ & 5 & 75.215 & 1.006 & .413 & .007 \\
Intercept & 97160416.118 & 1 & 97160416.118 & 1299593.383 & .000 & .999 \\
Device & 61.113 & 2 & 30.556 & .409 & .665 & .001 \\
Period & 145.946 & 1 & 145.946 & 1.952 & .163 & .003 \\
Device * Period & 39.009 & 2 & 19.505 & .261 & .770 & .001 \\
Error & 51884.943 & 694 & 74.762 & & & \\
Total & $1.306 \mathrm{E}$ & 700 & & & & \\
Corrected Total & 52261.016 & 699 & & & & \\
\hline
\end{tabular}

a. R Squared $=.007$ (Adjusted R Squared $=.000$ )

b. Computed using alpha $=.05$ 
SPSS Output for ANOVA - Performance by Content Area (DEVICE)

\section{Tests of Between-Subjects Effects}

Dependent Variable:Total SS

\begin{tabular}{|c|c|c|c|c|c|c|c|}
\hline Content & Source & $\begin{array}{c}\text { Type III Sum of } \\
\text { Squares }\end{array}$ & $\mathrm{df}$ & Mean Square & $F$ & Sig. & $\begin{array}{l}\text { Partial Eta } \\
\text { Squared }\end{array}$ \\
\hline \multirow[t]{8}{*}{ Math } & Cor. Model & $403.567^{a}$ & 5 & 80.713 & 1.085 & .372 & .039 \\
\hline & Intercept & 20063217.206 & 1 & 20063217.206 & 269663.892 & .000 & 1.000 \\
\hline & Device & 264.461 & 2 & 132.230 & 1.777 & .173 & .026 \\
\hline & Period & 154.592 & 1 & 154.592 & 2.078 & 152 & .015 \\
\hline & Dev * Period & 16.856 & 2 & 8.428 & .113 & .893 & .002 \\
\hline & Error & 9969.711 & 134 & 74.401 & & & \\
\hline & Total & 26901568.630 & 140 & & & & \\
\hline & Cor. Total & 10373.278 & 139 & & & & \\
\hline \multirow[t]{8}{*}{ Reading } & Cor. Model & $220.179^{c}$ & 5 & 44.036 & 1.153 & .336 & .041 \\
\hline & Intercept & 19242986.818 & 1 & 19242986.818 & 503723.945 & .000 & 1.000 \\
\hline & Device & 77.429 & 2 & 38.715 & 1.013 & .366 & .015 \\
\hline & Period & 59.285 & 1 & 59.285 & 1.552 & .215 & .011 \\
\hline & Dev * Period & 15.202 & 2 & 7.601 & .199 & .820 & .003 \\
\hline & Error & 5118.995 & 134 & 38.201 & & & \\
\hline & Total & 25874571.890 & 140 & & & & \\
\hline & Cor. Total & 5339.174 & 139 & & & & \\
\hline \multirow[t]{8}{*}{ Science } & Cor. Model & $129.468^{d}$ & 5 & 25.894 & .561 & .730 & .021 \\
\hline & Intercept & 18997033.592 & 1 & 18997033.592 & 411636.310 & .000 & 1.000 \\
\hline & Device & 48.747 & 2 & 24.374 & .528 & .591 & .008 \\
\hline & Period & 89.677 & 1 & 89.677 & 1.943 & .166 & .014 \\
\hline & Dev * Period & 3.924 & 2 & 1.962 & .043 & .958 & .001 \\
\hline & Error & 6184.106 & 134 & 46.150 & & & \\
\hline & Total & 25503772.590 & 140 & & & & \\
\hline & Cor. Total & 6313.574 & 139 & & & & \\
\hline \multirow{8}{*}{$\begin{array}{l}\text { Social } \\
\text { Studies }\end{array}$} & Cor. Model & $452.090^{\mathrm{e}}$ & 5 & 90.418 & 1.301 & .267 & .046 \\
\hline & Intercept & 19672989.309 & 1 & 19672989.309 & 283144.518 & .000 & 1.000 \\
\hline & Device & 70.609 & 2 & 35.304 & .508 & .603 & .008 \\
\hline & Period & 92.732 & 1 & 92.732 & 1.335 & .250 & .010 \\
\hline & Dev * Period & 110.435 & 2 & 55.217 & .795 & .454 & .012 \\
\hline & Error & 9310.371 & 134 & 69.480 & & & \\
\hline & Total & 26443091.430 & 140 & & & & \\
\hline & Cor. Total & 9762.461 & 139 & & & & \\
\hline \multirow[t]{8}{*}{ Writing } & Cor. Model & $560.762^{\dagger}$ & 5 & 112.152 & 1.758 & .126 & .062 \\
\hline & Intercept & 19193635.260 & 1 & 19193635.260 & 300908.295 & .000 & 1.000 \\
\hline & Device & 250.185 & 2 & 125.093 & 1.961 & .145 & .028 \\
\hline & Period & 149.311 & 1 & 149.311 & 2.341 & .128 & .017 \\
\hline & Dev * Period & 39.167 & 2 & 19.584 & .307 & .736 & .005 \\
\hline & Error & 8547.279 & 134 & 63.786 & & & \\
\hline & Total & 25909816.130 & 140 & & & & \\
\hline & Cor. Total & 9108.041 & 139 & & & & \\
\hline
\end{tabular}

a. $\mathrm{R}$ Squared $=.039$ (Adjusted R Squared $=.003$ )

b. Computed using alpha $=.05$

c. R Squared $=.041$ (Adjusted R Squared $=.005$ )

d. R Squared $=.021$ (Adjusted $R$ Squared $=-.016$ )

e. $\mathrm{R}$ Squared $=.046$ (Adjusted $\mathrm{R}$ Squared $=.011)$

f. $R$ Squared $=.062$ (Adjusted R Squared $=.027$ ) 
APPENDIX O 
Table O1

Between Group Effects (Q) by Pair

\begin{tabular}{|c|c|c|c|c|c|c|}
\hline Time & Pair & Content & $Q$ & $\mathrm{df}$ & $p$ & $\begin{array}{c}\text { Group } \\
\text { with } \\
\text { Greatest }+ \\
\text { Change }\end{array}$ \\
\hline \multirow[t]{30}{*}{1} & 1 & Math & 73.467 & 1 & 0.000 & $\mathrm{C}$ \\
\hline & & Reading & 0.443 & 1 & 0.506 & \\
\hline & & Science & 11.200 & 1 & 0.001 & $\mathrm{C}$ \\
\hline & & Social Studies & 5.714 & 1 & 0.017 & $\mathrm{C}$ \\
\hline & & Writing & 0.028 & 1 & 0.866 & \\
\hline & 2 & Math & 302.973 & 1 & 0.000 & $\mathrm{~T}$ \\
\hline & & Reading & 0.303 & 1 & 0.582 & \\
\hline & & Science & 88.746 & 1 & 0.000 & $\mathrm{~T}$ \\
\hline & & Social Studies & 0.024 & 1 & 0.878 & \\
\hline & & Writing & 22.033 & 1 & 0.000 & $\mathrm{~T}$ \\
\hline & 3 & Math & 115.667 & 1 & 0.000 & $\mathrm{~T}$ \\
\hline & & Reading & 29.863 & 1 & 0.000 & $\mathrm{C}$ \\
\hline & & Science & 0.034 & 1 & 0.877 & \\
\hline & & Social Studies & 36.729 & 1 & 0.000 & $\mathrm{C}$ \\
\hline & & Writing & 0.313 & 1 & 0.576 & \\
\hline & 4 & Math & 1.051 & 1 & 0.305 & \\
\hline & & Reading & 23.588 & 1 & 0.000 & $\mathrm{C}$ \\
\hline & & Science & 1.427 & 1 & 0.232 & \\
\hline & & Social Studies & 193.945 & 1 & 0.000 & $\mathrm{~T}$ \\
\hline & & Writing & 5.213 & 1 & 0.022 & $\mathrm{~T}$ \\
\hline & 5 & Math & 182.187 & 1 & 0.000 & $\mathrm{C}$ \\
\hline & & Reading & 59.861 & 1 & 0.000 & $\mathrm{C}$ \\
\hline & & Science & 457.918 & 1 & 0.000 & $\mathrm{C}$ \\
\hline & & Social Studies & 38.677 & 1 & 0.000 & $\mathrm{C}$ \\
\hline & & Writing & 134.277 & 1 & $\mathbf{0 . 0 0 0}$ & $\mathrm{C}$ \\
\hline & 6 & Math & 0.004 & 1 & 0.949 & \\
\hline & & Reading & 1.843 & 1 & 0.175 & \\
\hline & & Science & 0.574 & 1 & 0.449 & \\
\hline & & Social Studies & 39.669 & 1 & 0.000 & $\mathrm{~T}$ \\
\hline & & Writing & 34.087 & 1 & 0.000 & $\mathrm{~T}$ \\
\hline
\end{tabular}




\begin{tabular}{|c|c|c|c|c|c|}
\hline \multirow[t]{5}{*}{7} & Math & 0.143 & 1 & 0.705 & \\
\hline & Reading & 182.361 & 1 & 0.000 & $\mathrm{~T}$ \\
\hline & Science & 0.002 & 1 & 0.965 & \\
\hline & Social Studies & 154.683 & 1 & 0.000 & $\mathrm{~T}$ \\
\hline & Writing & 108.821 & 1 & 0.000 & $\mathrm{~T}$ \\
\hline \multirow[t]{5}{*}{8} & Math & 0.236 & 1 & 0.627 & \\
\hline & Reading & 185.904 & 1 & 0.000 & $\mathrm{C}$ \\
\hline & Science & 0.006 & 1 & 0.936 & \\
\hline & Social Studies & 11.656 & 1 & 0.001 & $\mathrm{~T}$ \\
\hline & Writing & 0.361 & 1 & 0.548 & \\
\hline \multirow[t]{5}{*}{9} & Math & 562.982 & 1 & 0.000 & $\mathrm{~T}$ \\
\hline & Reading & 6.162 & 1 & 0.013 & $\mathrm{~T}$ \\
\hline & Science & 0.313 & 1 & 0.576 & \\
\hline & Social Studies & 685.274 & 1 & 0.000 & $\mathrm{~T}$ \\
\hline & Writing & 358.454 & 1 & 0.000 & $\mathrm{~T}$ \\
\hline \multirow[t]{5}{*}{10} & Math & 0.294 & 1 & 0.587 & \\
\hline & Reading & 22.621 & 1 & 0.000 & $\mathrm{C}$ \\
\hline & Science & 107.524 & 1 & 0.000 & $\mathrm{~T}$ \\
\hline & Social Studies & 95.916 & 1 & 0.000 & $\mathrm{C}$ \\
\hline & Writing & 0.062 & 1 & 0.804 & \\
\hline \multirow[t]{5}{*}{11} & Math & 1.523 & 1 & 0.217 & \\
\hline & Reading & 21.491 & 1 & 0.000 & $\mathrm{C}$ \\
\hline & Science & 206.726 & 1 & 0.000 & $\mathrm{C}$ \\
\hline & Social Studies & 175.058 & 1 & 0.000 & $\mathrm{C}$ \\
\hline & Writing & 38.400 & 1 & 0.000 & $\mathrm{~T}$ \\
\hline \multirow[t]{5}{*}{12} & Math & 0.082 & 1 & 0.774 & \\
\hline & Reading & 1.155 & 1 & 0.283 & \\
\hline & Science & 0.137 & 1 & 0.711 & \\
\hline & Social Studies & 7.081 & 1 & 0.008 & $\mathrm{~T}$ \\
\hline & Writing & 0.011 & 1 & 0.916 & \\
\hline
\end{tabular}




\begin{tabular}{|c|c|c|c|c|c|c|}
\hline \multirow[t]{35}{*}{2} & 13 & Math & 149.689 & 1 & 0.000 & $\mathrm{C}$ \\
\hline & & Reading & 52.990 & 1 & 0.000 & $\mathrm{C}$ \\
\hline & & Science & 42.841 & 1 & 0.000 & $\mathrm{C}$ \\
\hline & & Social Studies & 22.364 & 1 & 0.000 & $\mathrm{C}$ \\
\hline & & Writing & 0.879 & 1 & 0.349 & \\
\hline & 14 & Math & 0.097 & 1 & 0.756 & \\
\hline & & Reading & 0.417 & 1 & 0.518 & \\
\hline & & Science & 0.283 & 1 & 0.595 & \\
\hline & & Social Studies & 11.632 & 1 & 0.001 & $\mathrm{~T}$ \\
\hline & & Writing & 7.561 & 1 & 0.006 & $\mathrm{~T}$ \\
\hline & 15 & Math & 0.004 & 1 & 0.948 & \\
\hline & & Reading & 0.222 & 1 & 0.638 & \\
\hline & & Science & 68.361 & 1 & 0.000 & $\mathrm{C}$ \\
\hline & & Social Studies & 137.515 & 1 & 0.000 & $\mathrm{C}$ \\
\hline & & Writing & 0.118 & 1 & 0.731 & \\
\hline & 16 & Math & 0.294 & 1 & 0.588 & \\
\hline & & Reading & 1.919 & 1 & 0.166 & \\
\hline & & Science & 0.070 & 1 & 0.791 & \\
\hline & & Social Studies & 4.862 & 1 & 0.027 & $\mathrm{~T}$ \\
\hline & & Writing & 0.159 & 1 & 0.690 & \\
\hline & 17 & Math & 8.643 & 1 & 0.003 & $\mathrm{C}$ \\
\hline & & Reading & 69.565 & 1 & 0.000 & $\mathrm{C}$ \\
\hline & & Science & 34.972 & 1 & 0.000 & $\mathrm{C}$ \\
\hline & & Social Studies & 2.759 & 1 & 0.097 & \\
\hline & & Writing & 0.011 & 1 & 0.915 & \\
\hline & 18 & Math & 40.368 & 1 & 0.000 & $\mathrm{~T}$ \\
\hline & & Reading & 23.352 & 1 & 0.000 & $\mathrm{~T}$ \\
\hline & & Science & 7.994 & 1 & 0.005 & $\mathrm{~T}$ \\
\hline & & Social Studies & 3.864 & 1 & 0.049 & $\mathrm{~T}$ \\
\hline & & Writing & 3.237 & 1 & 0.072 & \\
\hline & 19 & Math & 5.567 & 1 & 0.018 & $\mathrm{~T}$ \\
\hline & & Reading & 0.032 & 1 & 0.858 & \\
\hline & & Science & 9.145 & 1 & 0.002 & $\mathrm{C}$ \\
\hline & & Social Studies & 12.421 & 1 & 0.000 & $\mathrm{~T}$ \\
\hline & & Writing & 0.062 & 1 & 0.803 & \\
\hline
\end{tabular}




\begin{tabular}{|c|c|c|c|c|c|c|}
\hline \multirow[t]{10}{*}{3} & \multirow[t]{5}{*}{20} & Math & 0.013 & 1 & 0.909 & \\
\hline & & Reading & 18.512 & 1 & 0.000 & \multirow[t]{2}{*}{$\mathrm{T}$} \\
\hline & & Science & 3.272 & 1 & 0.070 & \\
\hline & & Social Studies & 39.997 & 1 & 0.000 & $\mathrm{C}$ \\
\hline & & Writing & 0.046 & 1 & 0.830 & \\
\hline & \multirow[t]{5}{*}{21} & Math & 318.006 & 1 & 0.000 & $\mathrm{~T}$ \\
\hline & & Reading & 164.655 & 1 & 0.000 & $\mathrm{~T}$ \\
\hline & & Science & 0.021 & 1 & 0.884 & \\
\hline & & Social Studies & 0.013 & 1 & 0.910 & \\
\hline & & Writing & 18.787 & 1 & 0.000 & $\mathrm{~T}$ \\
\hline \multirow[t]{15}{*}{4} & \multirow[t]{5}{*}{22} & Math & 7.163 & 1 & 0.007 & $\mathrm{C}$ \\
\hline & & Reading & 1.374 & 1 & 0.241 & \\
\hline & & Science & 9.646 & 1 & 0.002 & $\mathrm{C}$ \\
\hline & & Social Studies & 4.154 & 1 & 0.042 & $\mathrm{~T}$ \\
\hline & & Writing & 0.069 & 1 & 0.793 & \\
\hline & \multirow[t]{5}{*}{23} & Math & 180.964 & 1 & 0.000 & $\mathrm{C}$ \\
\hline & & Reading & 139.422 & 1 & 0.000 & $\mathrm{C}$ \\
\hline & & Science & 354.359 & 1 & 0.000 & $\mathrm{C}$ \\
\hline & & Social Studies & 201.378 & 1 & 0.000 & $\mathrm{C}$ \\
\hline & & Writing & 226.104 & 1 & 0.000 & $\mathrm{C}$ \\
\hline & \multirow[t]{5}{*}{24} & Math & 21.583 & $\mathbf{1}$ & 0.000 & $\mathrm{C}$ \\
\hline & & Reading & 0.062 & 1 & 0.803 & \\
\hline & & Science & 19.426 & 1 & 0.000 & $\mathrm{~T}$ \\
\hline & & Social Studies & 2.560 & 1 & 0.110 & \\
\hline & & Writing & 185.745 & 1 & 0.000 & $\mathrm{C}$ \\
\hline
\end{tabular}


Table $\mathrm{O} 2$

Math Standardized Effect Sizes (d) by Pair

\begin{tabular}{|c|c|c|c|c|c|c|c|c|c|}
\hline \multirow[b]{3}{*}{ Pair } & \multicolumn{4}{|c|}{ TREATMENT GROUP } & \multicolumn{4}{|c|}{ CONTROL GROUP } & \multirow[b]{3}{*}{$Q$} \\
\hline & \multirow[b]{2}{*}{$d$} & \multirow[b]{2}{*}{ SE } & \multicolumn{2}{|c|}{$95 \% \mathrm{CI}$} & \multirow[b]{2}{*}{$d$} & \multirow[b]{2}{*}{ SE } & \multicolumn{2}{|c|}{$95 \% \mathrm{CI}$} & \\
\hline & & & LL & UL & & & LL & UL & \\
\hline 1 & $-1.50^{* *}$ & 0.157 & -1.804 & -1.189 & $0.41 * *$ & 0.157 & 0.099 & 0.716 & $73.47 * *$ \\
\hline 2 & $3.02 * *$ & 0.154 & 2.722 & 3.325 & $-0.42 * *$ & 0.124 & -0.665 & -0.177 & $302.97 * *$ \\
\hline 3 & $1.01^{* *}$ & 0.214 & 0.593 & 1.433 & $-3.78 * *$ & 0.390 & -4.540 & -3.010 & $115.67 * *$ \\
\hline 4 & $6.67^{* *}$ & 0.413 & 5.858 & 7.475 & 0.26 & 0.161 & -0.058 & 0.575 & 1.05 \\
\hline 5 & $-0.56^{* *}$ & 0.124 & -0.800 & -0.314 & $1.88^{* *}$ & 0.131 & 1.625 & 2.140 & $182.19 * *$ \\
\hline 6 & $7.01 * *$ & 0.518 & 5.994 & 8.026 & $2.71 * *$ & 0.320 & 2.079 & 3.331 & 0.00 \\
\hline 7 & $1.35^{* *}$ & 0.122 & 1.110 & 1.587 & $7.54 * *$ & 0.320 & 6.913 & 8.166 & 0.14 \\
\hline 8 & $.50 * *$ & 0.128 & 0.254 & 0.756 & $4.30^{* *}$ & 0.217 & 3.871 & 4.720 & 0.24 \\
\hline 9 & $5.25 * *$ & 0.237 & 4.786 & 5.716 & $-1.01 * *$ & 0.115 & -1.235 & -0.783 & $562.98^{* *}$ \\
\hline 10 & $0.88^{* *}$ & 0.129 & 0.625 & 1.129 & $0.27 *$ & 0.119 & 0.041 & 0.506 & 0.29 \\
\hline 11 & -0.10 & 0.156 & -0.408 & 0.205 & 0.14 & 0.114 & -0.085 & 0.360 & 1.52 \\
\hline 12 & -0.34 & 0.184 & -0.703 & 0.020 & $-1.02 * *$ & 0.189 & -1.387 & -0.644 & 0.08 \\
\hline 13 & $1.57^{* *}$ & 0.186 & 1.204 & 1.935 & $6.41 * *$ & 0.349 & 5.725 & 7.093 & $149.69^{* *}$ \\
\hline 14 & $.97 * *$ & 0.172 & 0.637 & 1.310 & $1.37 * *$ & 0.162 & 1.051 & 1.685 & 0.10 \\
\hline 15 & $1.13^{* *}$ & 0.109 & 0.913 & 1.342 & $1.72 * *$ & 0.114 & 1.495 & 1.941 & 0.00 \\
\hline 16 & $1.25 * *$ & 0.156 & 0.940 & 1.552 & $1.11^{* *}$ & 0.174 & 0.779 & 1.459 & 0.29 \\
\hline 17 & $-2.19 * *$ & 0.126 & -2.435 & -1.941 & $0.44 * *$ & 0.114 & 0.216 & 0.664 & $8.64 * *$ \\
\hline 18 & 0.27 & 0.367 & -0.452 & 0.988 & $-4.50^{* *}$ & 0.655 & -5.786 & -3.219 & $40.37 * *$ \\
\hline 19 & $.81^{* *}$ & 0.225 & 0.370 & 1.250 & 0.09 & 0.207 & -0.317 & 0.495 & $5.57 *$ \\
\hline 20 & $.93 * *$ & 0.181 & 0.575 & 1.287 & $0.65^{* *}$ & 0.173 & 0.313 & 0.991 & 0.01 \\
\hline 21 & $4.99 * *$ & 0.202 & 4.592 & 5.384 & $0.85^{* *}$ & 0.114 & 0.627 & 1.074 & $318.01 * *$ \\
\hline 22 & 0.26 & 0.165 & -0.066 & 0.580 & $0.89^{* *}$ & 0.172 & 0.558 & 1.230 & $7.16^{* *}$ \\
\hline 23 & $-0.99 * *$ & 0.109 & -1.208 & -0.779 & $1.16^{* *}$ & 0.116 & 0.929 & 1.385 & $180.96^{* *}$ \\
\hline 24 & $-2.40 * *$ & 0.157 & -2.707 & -2.090 & $-1.38^{* *}$ & 0.153 & -1.679 & -1.081 & $21.58 * *$ \\
\hline Total & $0.48^{* *}$ & 0.032 & 0.417 & 0.544 & $.63^{* *}$ & 0.031 & 0.570 & 0.693 & \\
\hline
\end{tabular}


Table O3

Reading Standardized Effect Sizes (d) by Pair

\begin{tabular}{|c|c|c|c|c|c|c|c|c|c|}
\hline \multirow[b]{3}{*}{ Pair } & \multicolumn{4}{|c|}{ TREATMENT GROUP } & \multicolumn{4}{|c|}{ CONTROL GROUP } & \multirow[b]{3}{*}{$Q$} \\
\hline & & & & $\% \mathrm{CI}$ & \multirow[b]{2}{*}{$d$} & \multirow[b]{2}{*}{ SE } & \multicolumn{2}{|c|}{$95 \% \mathrm{CI}$} & \\
\hline & $d$ & SE & LL & UL & & & LL & UL & \\
\hline 1 & $-1.43 * *$ & 0.155 & -1.734 & -1.125 & $0.37 *$ & 0.157 & 0.064 & 0.680 & 0.443 \\
\hline 2 & $1.40 * *$ & 0.117 & 1.166 & 1.625 & $1.50^{* *}$ & 0.140 & 1.222 & 1.769 & 0.303 \\
\hline 3 & $0.76 * *$ & 0.209 & 0.354 & 1.173 & $2.93 * *$ & 0.337 & 2.270 & 3.592 & $29.863 * *$ \\
\hline 4 & 0.18 & 0.161 & -0.140 & 0.493 & $1.34 * *$ & 0.178 & 0.995 & 1.692 & $23.588^{* *}$ \\
\hline 5 & $-0.49 * *$ & 0.124 & -0.730 & -0.246 & $0.81 * *$ & 0.114 & 0.588 & 1.034 & $59.861 * *$ \\
\hline 6 & $0.70 * *$ & 0.200 & 0.304 & 1.087 & $1.13^{* *}$ & 0.251 & 0.639 & 1.622 & 1.843 \\
\hline 7 & $1.53 * *$ & 0.125 & 1.290 & 1.779 & $-0.77 * *$ & 0.117 & -1.001 & -0.544 & $182.361 * *$ \\
\hline 8 & $2.14 * *$ & 0.158 & 1.835 & 2.454 & $6.96^{* *}$ & 0.316 & 6.338 & 7.576 & $185.904 * *$ \\
\hline 9 & $0.77 * *$ & 0.117 & 0.543 & 1.001 & $-0.23 *$ & 0.109 & -0.441 & -0.014 & $6.162^{*}$ \\
\hline 10 & 0.05 & 0.123 & -0.191 & 0.290 & $0.88^{* *}$ & 0.123 & 0.635 & 1.118 & $22.621 * *$ \\
\hline 11 & 0.11 & 0.156 & -0.201 & 0.412 & $-0.83 * *$ & 0.118 & -1.059 & -0.595 & 21.491 \\
\hline 12 & $-1.01 * *$ & 0.194 & -1.387 & -0.625 & $-1.30 * *$ & 0.196 & -1.687 & -0.918 & 1.155 \\
\hline 13 & -0.19 & 0.163 & -0.510 & 0.131 & $1.47 * *$ & 0.159 & 1.158 & 1.780 & $52.99 * *$ \\
\hline 14 & $2.17 * *$ & 0.204 & 1.767 & 2.568 & $1.00^{* *}$ & 0.154 & 0.695 & 1.300 & 0.417 \\
\hline 15 & $0.31 * *$ & 0.103 & 0.114 & 0.516 & $0.38^{* *}$ & 0.098 & 0.190 & 0.574 & 0.222 \\
\hline 16 & $1.22 * *$ & 0.156 & 0.915 & 1.525 & $0.67 *$ & 0.280 & -0.080 & 1.230 & 1.919 \\
\hline 17 & $-0.53 * *$ & 0.101 & -0.730 & -0.333 & $0.76^{* *}$ & 0.117 & 0.531 & 0.990 & $69.565^{* *}$ \\
\hline 18 & $0.96^{*}$ & 0.385 & 0.201 & 1.710 & $-1.77 * *$ & 0.411 & -2.571 & -0.960 & $23.352 * *$ \\
\hline 19 & 0.17 & 0.216 & -0.256 & 0.592 & -0.20 & 0.208 & -0.607 & 0.207 & 0.032 \\
\hline 20 & $2.94 * *$ & 0.248 & 2.449 & 3.423 & $1.58^{* *}$ & 0.193 & 1.204 & 1.961 & $18.512^{* *}$ \\
\hline 21 & $4.42 * *$ & 0.190 & 4.047 & 4.790 & $1.51 * *$ & 0.124 & 1.269 & 1.755 & $164.655^{* *}$ \\
\hline 22 & $0.48 * *$ & 0.166 & 0.152 & 0.804 & $-0.53 * *$ & 0.166 & -0.857 & -0.205 & 1.374 \\
\hline 23 & $-1.33 * *$ & 0.114 & -1.554 & -1.106 & $0.54 * *$ & 0.110 & 0.326 & 0.756 & $139.422 * *$ \\
\hline 24 & $-1.28 * *$ & 0.132 & -1.538 & -1.021 & $-1.51 * *$ & 0.155 & -1.813 & -1.204 & 0.062 \\
\hline Total & $0.33 * *$ & 0.032 & 0.273 & 0.390 & $.45^{* *}$ & 0.031 & 0.390 & 0.507 & \\
\hline
\end{tabular}

Note. $\mathrm{CI}=$ Confidence Interval; $\mathrm{LL}=$ Lower limit; $\mathrm{UL}=$ Upper limit. $* p<.05, * * p<.001$ 
Table O4

Science Standardized Effect Sizes (d) by Pair

\begin{tabular}{|c|c|c|c|c|c|c|c|c|c|}
\hline \multirow[b]{3}{*}{ Pair } & \multicolumn{4}{|c|}{ TREATMENT GROUP } & \multicolumn{4}{|c|}{ CONTROL GROUP } & \multirow[b]{3}{*}{$Q$} \\
\hline & \multirow[b]{2}{*}{$d$} & \multirow[b]{2}{*}{$\mathrm{SE}$} & \multicolumn{2}{|c|}{$95 \% \mathrm{CI}$} & \multirow[b]{2}{*}{$d$} & \multirow[b]{2}{*}{ SE } & \multicolumn{2}{|c|}{$95 \% \mathrm{CI}$} & \\
\hline & & & LL & UL & & & LL & UL & \\
\hline 1 & $-2.33 * *$ & 0.18 & -2.68 & -1.98 & $0.41^{* *}$ & 0.16 & 0.10 & 0.72 & $11.20 * *$ \\
\hline 2 & $1.93 * *$ & 0.13 & 1.68 & 2.18 & $0.26^{*}$ & 0.12 & 0.02 & 0.50 & $88.75^{* *}$ \\
\hline 3 & $0.44^{*}$ & 0.20 & 0.04 & 0.84 & $0.65^{* *}$ & 0.24 & 0.18 & 1.12 & 0.03 \\
\hline 4 & $2.40 * *$ & 0.21 & 1.99 & 2.82 & $-0.82 * *$ & 0.17 & -1.15 & -0.49 & 1.43 \\
\hline 5 & $-1.99 * *$ & 0.15 & -2.28 & -1.70 & $2.44^{* *}$ & 0.14 & 2.16 & 2.72 & $457.92 * *$ \\
\hline 6 & $7.80 * *$ & 0.57 & 6.68 & 8.91 & $1.24 * *$ & 0.25 & 0.74 & 1.74 & 0.57 \\
\hline 7 & $1.09 * *$ & 0.12 & 0.86 & 1.32 & $0.79 * *$ & 0.12 & 0.56 & 1.02 & 0.00 \\
\hline 8 & $0.40^{* *}$ & 0.13 & 0.15 & 0.65 & $0.33^{* *}$ & 0.12 & 0.09 & 0.56 & 0.01 \\
\hline 9 & $8.91 * *$ & 0.37 & 8.18 & 9.64 & $-3.77 * *$ & 0.18 & -4.12 & -3.41 & 0.31 \\
\hline 10 & $2.11^{* *}$ & 0.15 & 1.81 & 2.41 & 0.10 & 0.12 & -0.13 & 0.34 & $107.52 * *$ \\
\hline 11 & $-2.80 * *$ & 0.22 & -3.23 & -2.37 & $0.79 * *$ & 0.12 & 0.56 & 1.02 & $206.73^{*}$ \\
\hline 12 & $0.67 * *$ & 0.19 & 0.30 & 1.04 & $-1.59 * *$ & 0.20 & -1.99 & -1.18 & 0.14 \\
\hline 13 & $0.32 *$ & 0.16 & 0.00 & 0.64 & $1.86^{* *}$ & 0.17 & 1.53 & 2.19 & $42.84 * *$ \\
\hline 14 & $3.02 * *$ & 0.24 & 2.56 & 3.49 & $1.68 * *$ & 0.17 & 1.35 & 2.01 & 0.28 \\
\hline 15 & -0.11 & 0.10 & -0.31 & 0.09 & $1.10 * *$ & 0.10 & 0.90 & 1.30 & $68.36^{* *}$ \\
\hline 16 & $1.34 * *$ & 0.16 & 1.03 & 1.65 & $0.99 * *$ & 0.17 & 0.65 & 1.32 & 0.07 \\
\hline 17 & $0.20 *$ & 0.10 & 0.01 & 0.40 & $1.14 * *$ & 0.12 & 0.90 & 1.38 & $34.97 * *$ \\
\hline 18 & $0.86^{*}$ & 0.38 & 0.12 & 1.61 & -0.61 & 0.36 & -1.31 & 0.09 & $7.99 * *$ \\
\hline 19 & -0.40 & 0.22 & -0.83 & 0.02 & $0.51 *$ & 0.21 & 0.10 & 0.93 & $9.15^{* *}$ \\
\hline 20 & $-0.44 *$ & 0.17 & -0.79 & -0.10 & $0.68 * *$ & 0.17 & 0.34 & 1.02 & 3.27 \\
\hline 21 & $3.30 * *$ & 0.16 & 2.99 & 3.61 & $2.15^{* *}$ & 0.14 & 1.88 & 2.42 & 0.02 \\
\hline 22 & 0.14 & 0.16 & -0.47 & 0.18 & $0.59 * *$ & 0.17 & 0.26 & 0.91 & $9.64 * *$ \\
\hline 23 & $-2.17 * *$ & 0.13 & -2.42 & -1.91 & $1.12 * *$ & 0.12 & 0.89 & 1.34 & $354.36^{* *}$ \\
\hline 24 & $0.42 * *$ & 0.12 & 0.18 & 0.66 & $-0.39 * *$ & 0.14 & -0.67 & -0.12 & $19.43 * *$ \\
\hline Total & $0.41 * *$ & 0.03 & 0.35 & 0.48 & $.63 * *$ & 0.03 & 0.58 & 0.70 & \\
\hline
\end{tabular}

Note. $\mathrm{CI}=$ Confidence Interval; $\mathrm{LL}=$ Lower limit; $\mathrm{UL}=$ Upper limit. ${ }^{*} p<.05,{ }^{* *} p<.001$ 
Table O5

Social Studies Standardized Effect Sizes (d) by Pair

\begin{tabular}{|c|c|c|c|c|c|c|c|c|c|}
\hline \multirow[b]{3}{*}{ Pair } & \multicolumn{4}{|c|}{ TREATMENT GROUP } & \multicolumn{4}{|c|}{ CONTROL GROUP } & \multirow[b]{3}{*}{$Q$} \\
\hline & \multirow[b]{2}{*}{$d$} & \multirow[b]{2}{*}{ SE } & \multicolumn{2}{|c|}{$95 \% \mathrm{CI}$} & \multirow[b]{2}{*}{$d$} & \multirow[b]{2}{*}{ SE } & \multicolumn{2}{|c|}{$95 \% \mathrm{CI}$} & \\
\hline & & & LL & UL & & & LL & UL & \\
\hline 1 & $-1.12 * *$ & 0.149 & -1.412 & -0.827 & 0.29 & 0.157 & -0.013 & 0.601 & $5.71 * *$ \\
\hline 2 & $1.08^{* *}$ & 0.113 & 0.862 & 1.304 & $-1.48^{* *}$ & 0.139 & -1.753 & -1.206 & 0.02 \\
\hline 3 & $0.87 * *$ & 0.211 & 0.455 & 1.283 & $-1.13^{* *}$ & 0.252 & -1.620 & -0.630 & $36.73 * *$ \\
\hline 4 & $3.37 * *$ & 0.251 & 2.879 & 3.862 & $-0.83^{* *}$ & 0.167 & -1.156 & -0.499 & $193.95 * *$ \\
\hline 5 & $-1.26^{* *}$ & 0.133 & -1.521 & -1.000 & -0.19 & 0.110 & -0.403 & 0.027 & $38.68 * *$ \\
\hline 6 & $3.17 * *$ & 0.291 & 2.600 & 3.743 & $0.79^{* *}$ & 0.242 & 0.311 & 1.260 & $39.67 * *$ \\
\hline 7 & $3.13 * *$ & 0.164 & 2.814 & 3.456 & $0.64^{* *}$ & 0.115 & 0.417 & 0.870 & $154.68^{* *}$ \\
\hline 8 & $1.07 * *$ & 0.135 & 0.800 & 1.330 & $0.45^{* *}$ & 0.121 & 0.210 & 0.683 & $11.66^{* *}$ \\
\hline 9 & $2.30^{* *}$ & 0.146 & 2.016 & 2.589 & $-3.80 * *$ & 0.182 & -4.161 & -3.448 & $685.27^{* *}$ \\
\hline 10 & -0.23 & 0.123 & -0.472 & 0.011 & $1.56^{* *}$ & 0.135 & 1.297 & 1.827 & $95.92 * *$ \\
\hline 11 & $-2.30^{* *}$ & 0.201 & -2.696 & -1.907 & $0.79^{* *}$ & 0.118 & 0.555 & 1.018 & $175.06^{* *}$ \\
\hline 12 & $-0.95 * *$ & 0.194 & -1.334 & -0.574 & $-1.71 * *$ & 0.208 & -2.120 & -1.303 & $7.08 * *$ \\
\hline 13 & $0.40^{*}$ & 0.164 & 0.075 & 0.720 & $1.48^{* *}$ & 0.159 & 1.168 & 1.791 & $22.36^{* *}$ \\
\hline 14 & $1.40^{* *}$ & 0.181 & 1.046 & 1.757 & $0.60^{* *}$ & 0.149 & 0.309 & 0.893 & $11.63 * *$ \\
\hline 15 & $-0.99 * *$ & 0.108 & -1.204 & -0.781 & $0.74^{* *}$ & 0.101 & 0.539 & 0.933 & $137.52 * *$ \\
\hline 16 & $0.76^{* *}$ & 0.148 & 0.466 & 1.046 & 0.27 & 0.162 & -0.046 & 0.589 & $4.86^{*}$ \\
\hline 17 & $-1.04 * *$ & 0.106 & -1.251 & -0.834 & $0.51^{* *}$ & 0.115 & 0.284 & 0.734 & 2.76 \\
\hline 18 & $-0.81^{*}$ & 0.380 & -1.552 & -0.064 & $-1.92 * *$ & 0.422 & -2.750 & -1.097 & $3.86^{*}$ \\
\hline 19 & $0.53 *$ & 0.220 & 0.095 & 0.956 & $-0.55 * *$ & 0.211 & -0.962 & -0.135 & $12.42 * *$ \\
\hline 20 & 0.26 & 0.173 & -0.084 & 0.595 & $1.95^{* *}$ & 0.205 & 1.550 & 2.353 & $40.00 * *$ \\
\hline 21 & $1.61 * *$ & 0.119 & 1.381 & 1.847 & $1.06^{* *}$ & 0.117 & 0.827 & 1.284 & 0.01 \\
\hline 22 & $1.20 * *$ & 0.178 & 0.850 & 1.548 & $-0.43 * *$ & 0.166 & -0.754 & -0.105 & $4.15^{*}$ \\
\hline 23 & $0.52 * *$ & 0.105 & 0.317 & 0.730 & $3.31^{* *}$ & 0.166 & 2.985 & 3.636 & $201.38^{* *}$ \\
\hline 24 & $-0.47 * *$ & 0.122 & -0.708 & -0.231 & $1.06^{* *}$ & 0.146 & 0.774 & 1.348 & 2.56 \\
\hline Total & $033 * *$ & 0.030 & 0.266 & 0.384 & $.37 * *$ & 0.030 & 0.315 & $0 . .433$ & \\
\hline
\end{tabular}

Note. $\mathrm{CI}=$ Confidence Interval; $\mathrm{LL}=$ Lower limit; $\mathrm{UL}=$ Upper limit. $* p<.05,{ }^{* *} p<.001$ 
Table O6

Writing Standardized Effect Sizes (d) by Pair

\begin{tabular}{|c|c|c|c|c|c|c|c|c|c|}
\hline \multirow[b]{3}{*}{ Pair } & \multicolumn{4}{|c|}{ TREATMENT GROUP } & \multicolumn{4}{|c|}{ CONTROL GROUP } & \multirow[b]{3}{*}{$Q$} \\
\hline & \multirow[b]{2}{*}{$d$} & \multirow[b]{2}{*}{ SE } & \multicolumn{2}{|c|}{$95 \% \mathrm{CI}$} & \multirow[b]{2}{*}{$d$} & \multirow[b]{2}{*}{ SE } & \multicolumn{2}{|c|}{$95 \% \mathrm{CI}$} & \\
\hline & & & LL & UL & & & LL & UL & \\
\hline 1 & $-0.98 * *$ & 0.147 & -1.271 & -0.696 & $-0.74 * *$ & 0.161 & -1.052 & -0.420 & 0.03 \\
\hline 2 & -0.03 & 0.105 & -0.237 & 0.175 & $-0.83 * *$ & 0.129 & -1.083 & -0.579 & $22.03 * *$ \\
\hline 3 & -0.07 & 0.202 & -0.463 & 0.328 & $-2.26^{* *}$ & 0.300 & -2.851 & -1.674 & 0.31 \\
\hline 4 & $-0.45^{* *}$ & 0.163 & -0.771 & -0.132 & $-2.11 * *$ & 0.200 & -2.499 & -1.717 & $5.21 *$ \\
\hline 5 & $-2.33 * *$ & 0.158 & -2.643 & -2.024 & -0.11 & 0.109 & -0.320 & 0.109 & $134.28^{* *}$ \\
\hline 6 & $1.88 * *$ & 0.233 & 1.428 & 2.342 & -0.04 & 0.234 & -0.500 & 0.416 & $34.09 * *$ \\
\hline 7 & 0.09 & 0.110 & -0.128 & 0.302 & $-1.70 * *$ & 0.131 & -1.952 & -1.439 & $108.82 * *$ \\
\hline 8 & $-0.53 * *$ & 0.129 & -0.777 & -0.273 & $-0.42 * *$ & 0.121 & -0.656 & -0.183 & 0.36 \\
\hline 9 & $0.76^{* *}$ & 0.117 & 0.526 & 0.985 & $-2.96 * *$ & 0.157 & -3.266 & -2.650 & $358.45^{* *}$ \\
\hline 10 & $-0.57 * *$ & 0.125 & -0.818 & -0.327 & $-0.62 * *$ & 0.121 & -0.853 & -0.380 & 0.06 \\
\hline 11 & $-1.43 * *$ & 0.176 & -1.770 & -1.082 & $-2.91 * *$ & 0.163 & -3.231 & -2.591 & $38.4 * *$ \\
\hline 12 & $-0.73 * *$ & 0.189 & -1.086 & -0.346 & $-1.21 * *$ & 0.194 & -1.590 & -0.829 & 0.01 \\
\hline 13 & $-0.41^{*}$ & 0.165 & -0.720 & -0.075 & $0.61 * *$ & 0.144 & 0.324 & 0.889 & 0.88 \\
\hline 14 & $0.85^{* *}$ & 0.170 & 0.521 & 1.187 & 0.24 & 0.146 & -0.047 & 0.524 & $7.56^{* *}$ \\
\hline 15 & $-0.69 * *$ & 0.105 & -0.891 & -0.480 & $-0.55^{* *}$ & 0.099 & -0.744 & -0.354 & 0.12 \\
\hline 16 & $-0.41 * *$ & 0.145 & -0.691 & -0.125 & 0.09 & 0.162 & -0.229 & 0.404 & 0.16 \\
\hline 17 & $-1.13 * *$ & 0.108 & -1.343 & -0.921 & $-0.67 * *$ & 0.116 & -0.895 & -0.439 & 0.01 \\
\hline 18 & -0.47 & 0.371 & -1.197 & 0.256 & $-1.44 * *$ & 0.391 & -2.207 & -0.673 & 3.24 \\
\hline 19 & $-0.51^{*}$ & 0.219 & -0.943 & -0.083 & $-0.77 * *$ & 0.215 & -1.186 & -0.345 & 0.06 \\
\hline 20 & -0.02 & 0.172 & -0.353 & 0.323 & 0.04 & 0.169 & -0.294 & 0.367 & 0.05 \\
\hline 21 & $0.94 * *$ & 0.113 & 0.717 & 1.159 & $0.26^{*}$ & 0.110 & 0.040 & 0.471 & $18.79 * *$ \\
\hline 22 & $-3.17 * *$ & 0.246 & -3.654 & -2.688 & $-1.32 * *$ & 0.180 & -1.669 & -0.962 & 0.07 \\
\hline 23 & $-2.76^{* *}$ & 0.145 & -3.044 & -2.477 & -0.05 & 0.108 & -0.260 & 0.163 & $226.10^{* *}$ \\
\hline 24 & $-5.12 * *$ & 0.248 & -5.604 & -4.632 & $-1.18^{* *}$ & 0.148 & -1.470 & -0.888 & $185.75^{* *}$ \\
\hline Total & $\begin{array}{c}- \\
0.512 * *\end{array}$ & 0.030 & -0.455 & -0.571 & -0.659 & 0.030 & -0.717 & -0.601 & \\
\hline
\end{tabular}

Note. $\mathrm{CI}=$ Confidence Interval; $\mathrm{LL}=$ Lower limit; $\mathrm{UL}=$ Upper limit. ${ }^{*} p<.05,{ }^{* *} p<.001$ 
APPENDIX P 


\section{Table 6: Description of Implementation Indicators for Technology}

Immersion

\begin{tabular}{|c|c|}
\hline \multicolumn{2}{|r|}{ Support for Technology Immersion } \\
\hline Leadership & $\begin{array}{l}\text { To what extent do teachers indicate that administrators establish a clear vision and } \\
\text { expectations, encourage integration, provide supports, and involve staff in making } \\
\text { decisions about instructional technology. }\end{array}$ \\
\hline $\begin{array}{l}\text { Teacher } \\
\text { Support }\end{array}$ & $\begin{array}{l}\text { To what extent do teachers share an understanding about technology use, do } \\
\text { teachers continually learn and seek new ideas, are teachers unafraid to learn about } \\
\text { and use technologies, and are teachers supportive of integration efforts. }\end{array}$ \\
\hline $\begin{array}{l}\text { Parent and } \\
\text { Community } \\
\text { Support }\end{array}$ & $\begin{array}{l}\text { To what extent do teachers believe that parents and the surrounding community } \\
\text { support the school's efforts with technology. }\end{array}$ \\
\hline $\begin{array}{l}\text { Technical } \\
\text { Support }\end{array}$ & $\begin{array}{l}\text { To what extent do teachers indicate that technical problems with computers, Internet } \\
\text { access, repairs, and material availability pose barriers to Technology Immersion. }\end{array}$ \\
\hline \multirow{4}{*}{$\begin{array}{l}\text { Professional } \\
\text { Development }\end{array}$} & $\begin{array}{l}\text { Contact Hours To what extent does the duration (hours) of technology-related } \\
\text { professional development (PD) support the integration of technology into teaching, } \\
\text { learning, and the curriculum. }\end{array}$ \\
\hline & $\begin{array}{l}\text { Classroom Support To what extent do core-subject teachers receive coaching } \\
\text { or mentoring from an internal source, such as another teacher or technology } \\
\text { coordinator, or an external (non-school) source. }\end{array}$ \\
\hline & $\begin{array}{l}\text { Content Focus To what extent do core-subject teachers indicate that PD emphasizes } \\
\text { curriculum, instructional methods, and lesson development in core subjects. }\end{array}$ \\
\hline & $\begin{array}{l}\text { Coherence To what extent do core-subject teachers indicate that PD is consistent } \\
\text { with personal and school goals, builds on prior learning, and supports state } \\
\text { standards and assessments. }\end{array}$ \\
\hline \multicolumn{2}{|r|}{ Classroom Immersion } \\
\hline \multicolumn{2}{|c|}{$\begin{array}{l}\text { Technology Integration To what extent do core teachers alter instructional practices, allocate } \\
\text { time, integrate research on teaching and learning, improve basic skills, and support higher order } \\
\text { thinking through technology. }\end{array}$} \\
\hline \multicolumn{2}{|c|}{$\begin{array}{l}\text { Learner-Centered Instruction To what extent do teachers have students establish learning goals, } \\
\text { use information and inquiry skills, complete alternative assessments, and have active and relevant } \\
\text { learning experiences. }\end{array}$} \\
\hline \multicolumn{2}{|c|}{$\begin{array}{l}\text { Student Classroom Activities To what extent do teachers have students use particular technology } \\
\text { resources for learning in core-subject classes, such as a word processor for writing, a spreadsheet } \\
\text { for calculation or graphing, or the Internet for research. }\end{array}$} \\
\hline \multicolumn{2}{|c|}{$\begin{array}{l}\text { Communication To what extent do teachers use technology to communicate with students, parents, } \\
\text { and colleagues or to post information on a class website. }\end{array}$} \\
\hline \multicolumn{2}{|c|}{$\begin{array}{l}\text { Professional Productivity To what extent do teachers use technology to enhance their professional } \\
\text { productivity (e.g., keep records, analyze data, develop lessons, deliver information). }\end{array}$} \\
\hline \multicolumn{2}{|r|}{ Student Access and Use } \\
\hline \multicolumn{2}{|c|}{ Laptop Access To what extent do students have access to wireless laptops throughout the scl } \\
\hline \multicolumn{2}{|c|}{$\begin{array}{l}\text { Core-Subject Learning How frequently do students use technology resources for learning in } \\
\text { core-subject classes. }\end{array}$} \\
\hline \multicolumn{2}{|c|}{$\begin{array}{l}\text { Home Learning To what extent do students have access to and use laptops outside of the school } \\
\text { for homework and learning. }\end{array}$} \\
\hline
\end{tabular}

(Shapley et al., 2010, p. 19) 
APPENDIX Q 


\section{Youngstown}

One Univiersity Plaza. Youngstown. Ohio 44555

Office of Grants and Sponsored Programs

330.941 .2377

Fax 330.944 .2705

Seplember 24, 2013

Dr. Karen Lawin. Principal Investigator

Ms. Nancy Williams, Co-investigator

Department of Educational Fotndations, Research. Technology and Leadership UNIVERSITY

RE: HSRC Protocol Number; $\quad 025-2014$

Title: One-to-One Computing and Student Achevenent in Ohio High Sonools

Dear Dr. Lamin and Ms. Williams:

The Institutional Review Board has reviewed the abovementioned protocol and deternined that it is exempt from full commitec revicw based on a DHHS Category 5 exemption.

Any changes in your research activity should be promply reported to the Institutional Revicu Bond and may not be initated withou IRB approval except where necessary to eliminate hazard to human subjects. Any unanticipated problems involving risks to subjects should also be promptly reported to the IRB.

The IRB would like to extend is best wishes to you in the conduct of this study.

Sincerely,

Dr. Scon Martin

Intcrim Associate Dean for Resenteh

Authorized Institutional Official

$\mathrm{SCM} / \mathrm{CC}$

¿ Ny/Aord Sution, Chat

Youngstown if thment of Educational Foundations, Restarch, Techiology and Leadership 100 (n)

100

www.ysu.edu $Y=1$ 